\title{
CONTROLE DO PERCEVEJO-DE-RENDA-DA-SERINGUEIRA (Leptopharsa heveae) COM FUNGOS ENTOMOPATOGÊNICOS
}

\author{
MARCEL RiCARDo TANZINI
}

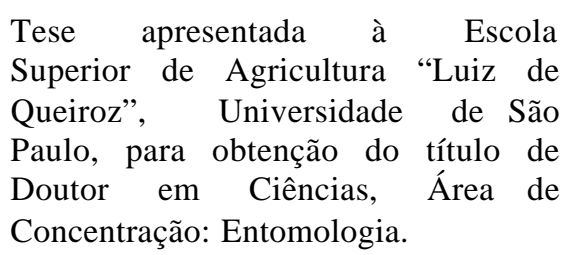

PIRACICABA

Estado de São Paulo - Brasil

Fevereiro - 2002 


\section{CONTROLE DO PERCEVEJO-DE-RENDA-DA-SERINGUEIRA (Leptopharsa heveae) COM FUNGOS ENTOMOPATOGÊNICOS}

\section{MARCEL RICARDO TANZINI}

Engenheiro Agrônomo

Orientador: Prof. Dr. SÉRGIO BATISTA ALVES

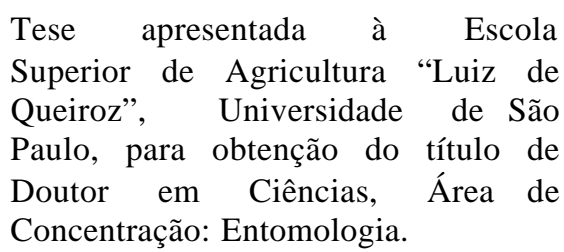

PIRACICABA

Estado de São Paulo - Brasil

Fevereiro - 2002 
Dados Internacionais de Catalogação na Publicação (CIP)

DIVISÃO DE BIBLIOTECA E DOCUMENTAÇÃO - ESALQ/USP

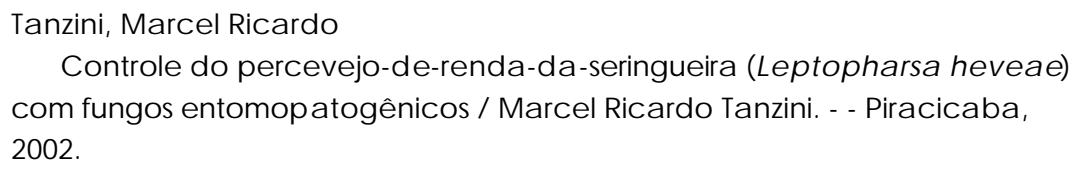

1. Controle biológico (Fitossanidade) 2. Fungos entompatogênicos 3. Percevejo-de-renda 4. Seringueira I. Título 


\section{AGRADECIMENTOS}

Ao Prof. Sérgio Batista Alves, pela amizade, orientação, apoio, confiança e respeito demonstrado durante nosso convívio.

Aos Professores do Setor de Entomologia, pela ajuda e colaboração no desenvolvimento deste trabalho e no decorrer do curso de Doutorado.

Aos amigos do Laboratório de Patologia e Controle Microbiano: Adriana, Solange, Daniella, Tamai, Rogério, Ricardo, Marcos, Luciana, Melissa, Michele, Marcelo, Leonardo e Luis pelo companheirismo e colaboração no desenvolvimento desta pesquisa.

À Plantações E. Michelin, Itiquira-MT, Fazenda Santa Maria, Caçú-GO e Estação Experimental de Pindorama- SP pela colaboração e apoio logístico para o desenvolvimento desta pesquisa.

As bibliotecárias Eliana M. Garcia, Silvia M. Zinsly e Kátia M. de A. Ferraz pela revisão e normatização desta tese.

À Fundação de Amparo à Pesquisa do Estado de São Paulo - FAPESP, pelo suporte financeiro desta pesquisa. 
Ao Prof. Sérgio B. AlVes, Que encontrou forÇas Para Voltar a ENSINAR E NOS ORIENTAR.

\section{OFEREÇO}

A mulher da minha Vida Ana Lúcia (eSPOSA), Marilene (Mãe), Odete (TIA) E MARIA HELENA (ETERNA PROFESSORA)

\section{Dedico}




\section{SUMÁRIO}

Página

LISTA DE FIGURAS.......................................................................... viii

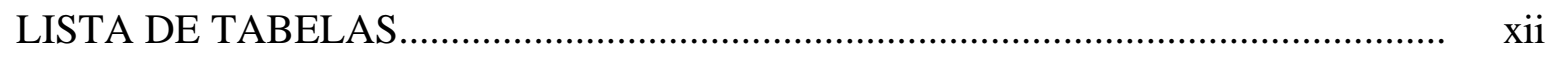

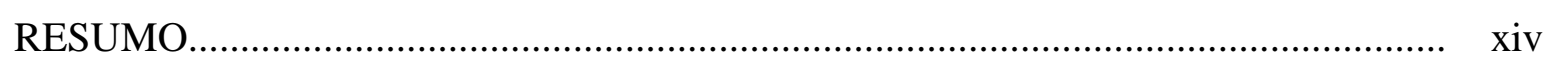

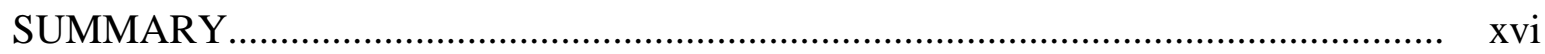

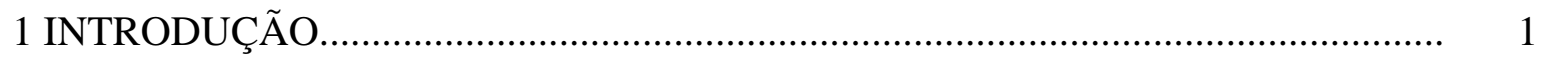

2 REVISÃO DE LITERATURA..................................................................... 3

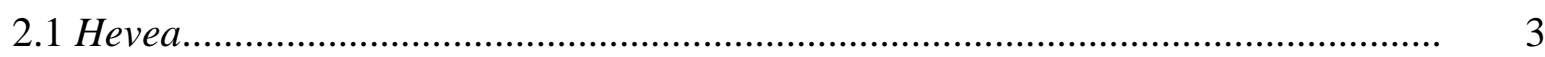

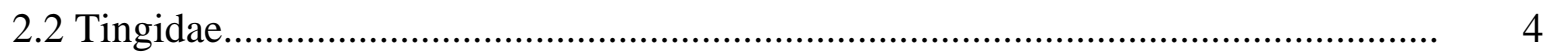

2.2.1 Prejuízos causados por Leptopharsa heveae em seringueira.............................. 5

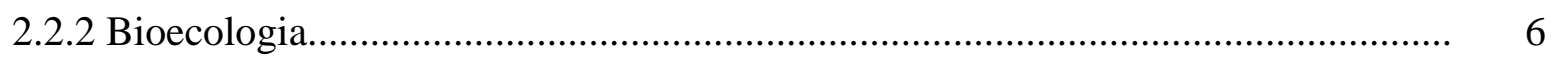

2.2.3 Controle Químico.................................................................................. 8

2.2.4 Controle Biológico.................................................................................. 8

3 EPIZOOTIOLOGIA DE FUNGOS ENTOMOPATOGÊNICOS SOBRE PERCEVEJO-

DE-RENDA-DA-SERINGUEIRA Leptopharsa heveae .......................................... 12

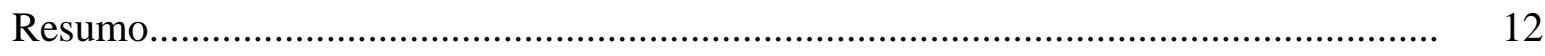

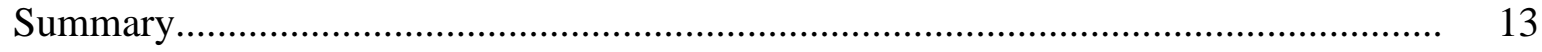

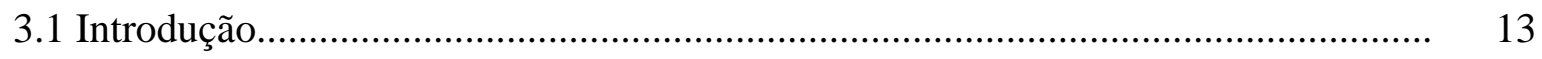

3.2 Material e Métodos..................................................................................... 15

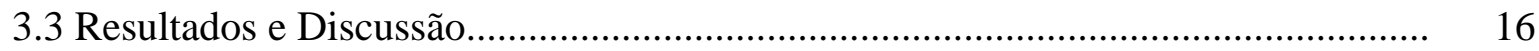

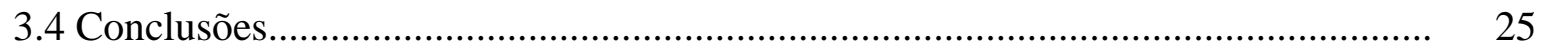


4 SELEÇÃO DE ISOLADOS DE FUNGOS ENTOMOPATOGÊNICOS VISANDO AO CONTROLE DE Leptopharsa heveae ......................................................................... 26

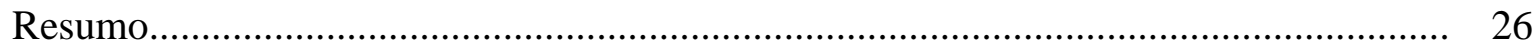

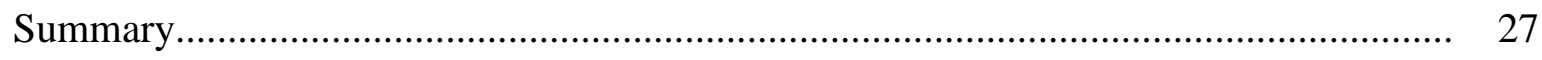

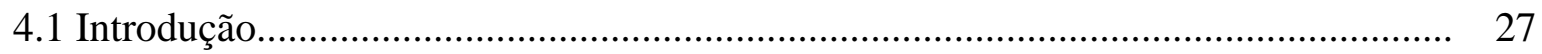

4.2 Material e Métodos......................................................................................... 29

4.3 Resultados e Discussão....................................................................................... 34

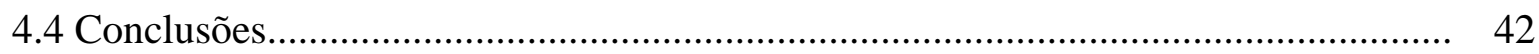

5 UTILIZAÇÃO DE FUNGOS ENTOMOPATOGÊNICOS VISANDO AO CONTROLE DE Leptopharsa heveae EM SERINGUEIRA.............................................................. 43

Resumo................................................................................................. 43

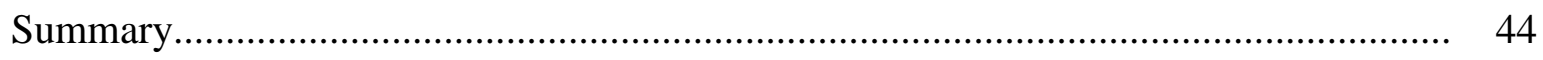

5.1 Introdução.............................................................................................. 44

5.2 Material e Métodos.................................................................................... 46

5.2.1 Avaliação de diferentes concentrações de fungos em condições de campo............. 46

5.2.1.1 Ensaio 1- Controle do percevejo-de-renda-seringueira em Itiquira-MT.............. 46

5.2.1.2 Ensaio 2- Controle do percevejo-de-renda-seringueira em Caçú-GO................... 46

5.2.2 Avaliação de diferentes fungos no controle de Leptopharsa heveae na cultura da

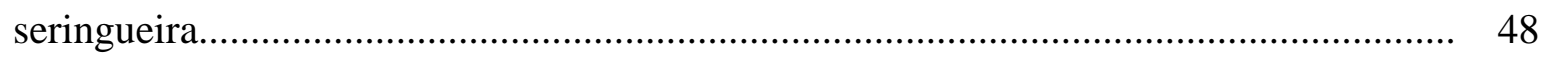

5.3 Resultados e Discussão.......................................................................... 50

5.3.1 Avaliação de diferentes concentrações de fungos em condições de campo............ 50

5.3.1.1 Ensaio 1- Controle do percevejo-de-renda-seringueira em Itiquira-MT.............. 50

5.3.1.2 Ensaio 2- Controle do percevejo-de-renda-seringueira em Caçú-GO.................. 55

5.3.2 Avaliação de diferentes fungos no controle de Leptopharsa heveae na cultura da seringueira............................................................................................. 58

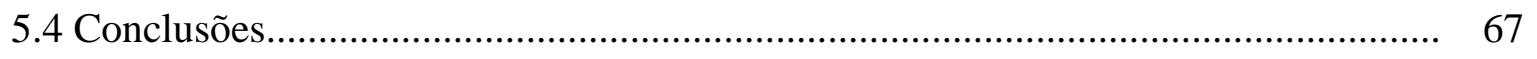

6 TOXICIDADE DE PRODUTOS FITOSSANITÁRIOS UTILIZADOS NO CONTROLE DE Leptopharsa heveae PARA FUNGOS ENTOMOPATOGÊNICOS............................. 68

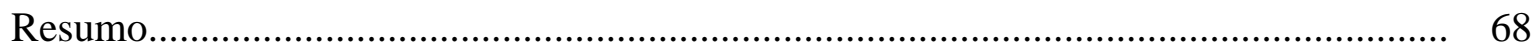




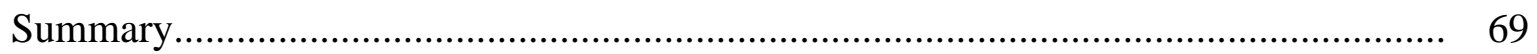

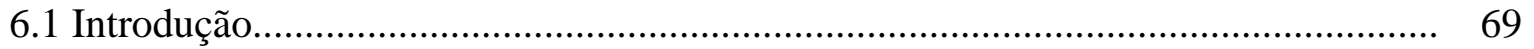

6.2 Material e Métodos............................................................................................... 71

6.3 Resultados e Discussão....................................................................................... 73

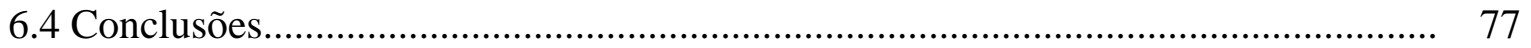

7 PRODUÇÃO DE FUNGOS ENTOMOPATOGÊNICOS PARA O CONTROLE DE Leptopharsa heveae .............................................................................................. 79

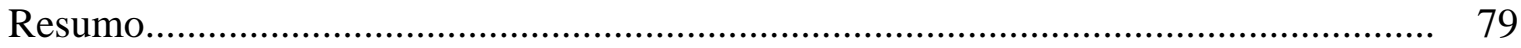

Summary



7.2 Material e Métodos........................................................................................ 82

7.2.1 Produção em meios líquidos............................................................................ 82

7.2.2 Avaliação dos métodos de produção...................................................................... 83

7.3 Resultados e Discussão................................................................................... 86

7.3.1 Produção em meios líquidos................................................................................ 86

7.3.2 Avaliação dos métodos de produção...................................................................... 89

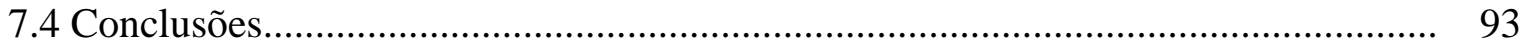

8 CICLO BIO.LÓGICO DE FUNGOS ENTOMOPATOGÊNICOS SOBRE Leptopharsa

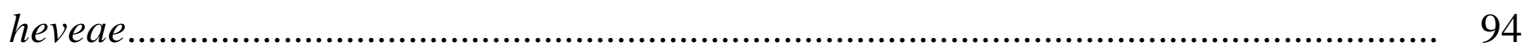

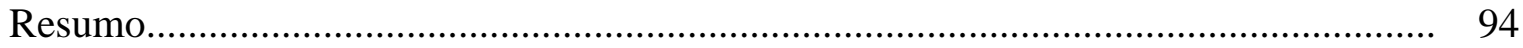

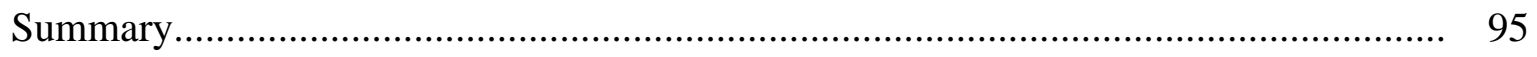

8.1 Introdução..................................................................................................... 95

8.2 Material e Métodos......................................................................................... 96

8.3 Resultados e Discussão................................................................................ 98

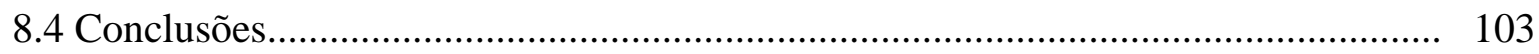

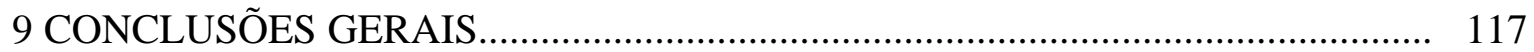

REFERÊNCIAS BIBLIOGRÁFICAS..................................................................... 120 


\section{LISTA DE FIGURAS}

Página

1 Número de ninfas de Leptopharsa heveae/folha de seringueira e porcentagem de mortalidade causada por fungos nos clones RRIM 600, PR 107, PB 235 e GT 1 (Pindorama-SP, 2000).

2 Temperaturas máxima e mínima $\left({ }^{\circ} \mathrm{C}\right)$ e precipitação pluviométrica $(\mathrm{mm})$ de agosto de 1998 a agosto de 2000 (Pindorama-SP, 2000).

3 Número de adultos de Leptopharsa heveae/folha de seringueira e porcentagem de mortalidade causada por fungos nos clones RRIM 600, PR 107, PB 235 e GT 1 (Pindorama-SP, 2000)

4 Leptopharsa heveae contaminado com fungo da ordem Entomophthorales (PindoramaSP, 2000).

5 Número médio de ninfas e adultos de Leptopharsa heveae, total de insetos contaminados por fungos, temperaturas máxima e mínima de agosto de 1998 a julho de 2000 (Itiquira-MT, 2000)

6 Placa de plástico $(6 \times 1,5 \mathrm{~cm})$ com ágar-água $(2 \%)$ e folha de seringueira $(5 \mathrm{~cm} \varnothing)$ utilizada para a realização de bioensaios com Leptopharsa heveae (Piracicaba-SP, 1999). 
7 Porcentagens de mortalidade corrigida de ninfas de Leptopharsa heveae, 2 dias (cor clara) e 4 dias (cor escura) após a inoculação com os isolados de fungos entomopatogênicos (Piracicaba-SP, 1999) 37

8 Porcentagens de mortalidade corrigida de ninfas de Leptopharsa heveae, 2 dias (cor clara) e 4 dias (cor escura) após a inoculação com os isolados de fungos entomopatogênicos (continuação) (Piracicaba-SP, 1999).

9 Ninfa de Leptopharsa heveae colonizada pelo fungo Trichoderma sp. No detalhe esporos aderidos e formação de conidióforos sobre o inseto (Piracicaba-SP, 1999).

10 A- Turbo atomizador, série seringueira da FMCopling, utilizado para aplicação dos tratamentos nas áreas dos ensaios em Caçú-GO e Itiquira-MT. B e C-Aplicação de suspensão conidial de fungo com vazão de 300 L/ha em seringal com alta infestação de Leptopharsa heveae (Itiquira-MT, 2000)

11 Eficiência de controle de ninfas de Leptopharsa heveae aos 17 e 34 dias após aplicação com diferentes concentrações de fungos entomopatogênicos (Itiquira-MT, 2001).

12 Eficiência de controle de adultos de Leptopharsa heveae aos 17 e 34 dias após aplicação com diferentes concentrações e fungos entomopatogênicos (Itiquira-MT, 2001).

13 Eficiência de Beauveria bassiana, isolado 1196, no controle de ninfas de Leptopharsa heveae (Caçú-GO, 2001). 56

14 Eficiência de Beauveria bassiana, isolado 1196, no controle de adultos de Leptopharsa heveae em (Caçú-GO, 2001). 
15 Eficiência de Metarhizium anisopliae, isolado 1104, no controle de ninfas de Leptopharsa heveae (Caçú-GO, 2001)............................................................ 57

16 Eficiência de Metarhizium anisopliae, isolado 1104, no controle de ninfas de Leptopharsa heveae (Caçú-GO, 2001)........................................................... 57

17 Mortalidade de ninfas e adultos de Leptopharsa heveae, causada pelos fungos entomopatogênicos 20 dias após tratamento (Caçú-GO, 2001).............................. 61

18 Mortalidade de ninfas de Leptopharsa heveae aos 5 e 10 dias após aplicação de fungos entomopatogênicos (Itiquira-MT, 2001)......................................................... 62

19 Mortalidade de adultos de Leptopharsa heveae, aos 5 e 10 dias após aplicação de fungos entomopatogênicos (Itiquira-MT, 2001)............................................. 63

20 Número de ninfas de Leptopharsa heveae/folha nas avaliações prévia, 6, 10 e 20 dias após aplicação com diferentes fungos entomopatogênicos (Itiquira-MT, 2001)....... 66

21 Número de adultos de Leptopharsa heveae/folha nas avaliações prévia, 6, 10 e 20 dias após aplicação com diferentes fungos entomopatogênicos (Itiquira-MT, 2001)....... 66

22 Desenvolvimento de fungos entomopatogênicos na presença de deltametrina (Decis 25 CE) na concentração de 200mL/ha (Piracicaba-SP, 2001).

23 Caixa de produção de fungos entomopatogênicos. A- Vazia com sistema de aeração e água. B- Com tela para suporte do substrato. C- Com o substrato inoculado (PiracicabaSP, 2001) 84

24 Produção de Metarhizium anisopliae pelo método de bandejas (Piracicaba-SP, 2001). 
25 Produção de conídios em meios líquidos (Piracicaba-SP, 2001).............................. 88

26 Produção de conídios de fungos entomopatogênicos obtidos nos diferentes processos

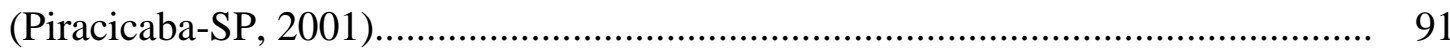

27 Ninfas de Leptopharsa heveae 72 h após aplicação de B. bassiana (no canto direito uma ninfa com sintoma de oosporina.) (Piracicaba-SP, 2001)............................. 102

28 Ninfa de Leptopharsa heveae no acme da conidiogênese de Beauveria bassiana

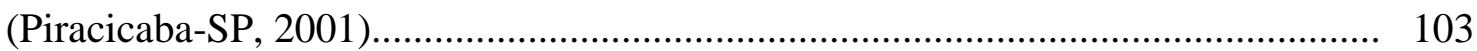




\section{LISTA DE TABELAS}

1 Isolados de fungos entomopatogênicos utilizados nos bioensaios com ninfas de Leptopharsa heveae (Piracicaba-SP, 1999)

2 Mortalidade corrigida e confirmada de ninfas do $4^{\circ}$ ínstar de Leptopharsa heveae, inoculadas com fungos entomopatogênicos na concentração de $1 \times 10^{8}$ conídios $/ \mathrm{mL}$ (Piracicaba-SP, 1999).

3 Isolados de fungos entomopatogênicos e concentrações utilizadas no controle de Leptopharsa heveae (Itiquira-MT, 2000)

4 Isolados de fungos entomopatogênicos e concentrações utilizadas no controle de Leptopharsa heveae (Caçú-GO, 2000).

5 Isolados dos fungos utilizados nos experimentos de Caçú-GO e Itiquira-MT, visando ao controle de Leptopharsa heveae.

6 Número de ninfas vivas/folha de Leptopharsa heveae, após a aplicação das concentrações de fungos entomopatogênicos (Itiquira-MT, 2001)........................... 52

7 Número de adultos vivos/folha de Leptopharsa heveae, após a aplicação das concentrações de fungos entomopatogênicos (Itiquira-MT, 2001)............................ 52

8 Número de ninfas vivas de Leptopharsa heveae por folha, observadas nos tratamentos com fungos (Caçú-GO, 2001) 
9 Número de adultos vivos de Leptopharsa heveae por folha, observados nos tratamentos com fungos (Caçú-GO, 2001).

10 Número de ninfas vivas de Leptopharsa heveae por folha, observadas nos tratamentos com fungos entomopatogênicos em (Itiquira-MT, 2001).

11 Número de adultos de Leptopharsa heveae vivos por folha, nos tratamentos com fungos entomopatogênicos (Itiquira-MT, 2001)

12 Número de ninfas vivas de Leptopharsa heveae por folha observadas nos tratamentos com fungos entomopatogênicos (Itiquira-MT, 2001)

13 Número de adultos vivos de Leptopharsa heveae por folha observados nos tratamentos com fungos entomopatogênicos (Itiquira-MT, 2001).....

14 Produtos fitossanitários utilizados nos ensaios de compatibilidade com os fungos entomopatogênicos selecionados para controle de Leptopharsa heveae (Piracicaba-SP, 2001)

15 Classificação da toxicidade de produtos químicos sobre fungos entomopatogênicos (Alves et al., 1998) (Piracicaba-SP, 2001).

16 Valores $\mathrm{T}$ e classificação da toxicidade dos produtos fitossanitários aos isolados de fungos selecionados para controle de Leptopharsa heveae (Piracicaba-SP, 2001). 


\title{
CONTROLE DO PERCEVEJO-DE-RENDA-DA-SERINGUEIRA (Leptopharsa heveae) COM FUNGOS ENTOMOPATOGÊNICOS
}

\author{
Autor: MARCEL RICARDO TANZINI \\ Orientador: PROF. DR. SÉRGIO BATISTA AlvES
}

\section{RESUMO}

Os estudos da epizootiologia foram realizados em Pindorama-SP e em Itiquira-MT durante dois anos. No primeiro local, constatou-se em agosto de 1998 uma epizootia de Sporothrix sp. em ninfas do percevejo. Em Itiquira, quando a infestação atingiu 56 ninfas e 18 adultos/folha, verificou-se a ocorrência natural de Sporothrix sp., reduzindo significativamente a população. $\mathrm{Na}$ seleção de fungos entomopatogênicos, testou-se sessenta isolados obtidos de diferentes hospedeiros e localidades sobre ninfas do $4^{\circ}$ ínstar. Os melhores isolados foram B. bassiana (619 e 1196) com 56 e 84\% de mortalidade com 3 dias após a inoculação, M. anisopliae (1144 e 1104) ambos com 90\%, S. insectorum (1229) com $92 \%$ e P. fumosoroseus (1200) com 100\%. Trichoderma sp., após quatro dias da inoculação causou $78 \%$ de mortalidade. Na avaliação de campo, as concentrações superiores a $10^{12}$ e $10^{13}$ conídios/ha foram eficientes para controle do percevejo sendo que os fungos P. fumosoroseus (1200), B. bassiana (447) e M. anisopliae (1175 e 1144) foram eficientes para controle de L. heveae. Nos estudos de toxicidade, as formulações Decis e Nuvacron foram compatíveis com B. brongniartii (619). A maioria das combinações, com exceção da formulação de Decis foi compatível com V. lecanii (972). M. anisopliae (1144) foi muito sensível para todas as formulações. Nuvacron e Stron foram compatíveis com $B$. bassiana (1196), P. fumosoroseus (1200) e S. insectorum (1229). Marshal foi compatível 
com B. bassiana (1196) e S. insectorum (1229) e Dipterex foi compatível com $P$. fumosoroseus (1200). Avaliou-se dois métodos de produção e dois meios de cultura para os fungos B. bassiana (1196), M. anisopliae (1189), Sporothrix insectorum (1229), Paecilomyces fumosoroseus (1200) e Verticillium lecanii (1200). Os fungos P. fumosoroseus e B. bassiana foram os que mais produziram pelo método da caixa. No método da bandeja, B. bassiana foi o fungo mais produtivo. Entre os métodos de produção testados $V$. lecanii produziu mais no método de bandeja e P. fumosoroseus no método da caixa. Em observações em Microscópio Eletrônico de Varredura LEO 435VP (MEV) verificou-se que em geral, todos os hifomicetos apresentaram ciclos biológicos semelhantes sobre $L$. heveae, tendo um período de adesão, germinação e início da penetração de $24 \mathrm{~h}$, crescimento vegetativo entre 48 e 72 h, e a extrusão e conidiogênse dos patógenos em 96 h. 


\title{
CONTROL OF RUBBER TREE LACEBUG Leptopharsa heveae WITH ENTOMOPATHOGENIC FUNGI
}

\author{
Author: MARCEL RICARDO TANZINI \\ Adviser: PROF. Dr. SÉRGIO BATISTA AlveS
}

\section{SUMMARY}

Studies on epizootiology were carried out in Pindorama-SP and Itiquira-MT, Brazil during two years. In Pindorama, in August 1998 an epizootic of Sporothrix sp. was observed in lacebug nymphs. In Itiquira, when the infestation reached 56 nymphs and 18 adults/leaf, a natural occurrence of Sporothrix sp. was observed, reducing significantly the pest population. Entomopathogenic fungi for use in lacebug control were selected from sixty isolates obtained from different hosts and applied to 4th instar nymphs. The best isolates were Beauveria bassiana (619 and 1196) with 56 and 84\% mortality 3 days after the inoculation Metarhizium anisopliae (1144 and 1104) both with 90\%, S. insectorum (1229) with 92\%, and Paecilomyces fumosoroseus (1200) with 100\%. Trichoderma sp. caused $78 \%$ of mortality four days after inoculation. In field evaluations, the concentrations above $10^{12}$ conidia/ha were efficient for control of the lacebug and the fungal isolates $P$. fumosoroseus (1200), B. bassiana (447) and M. anisopliae (1175 and 1144) were efficient for control of $L$. heveae. In the toxicity studies, the formulations Decis and Nuvacron were compatible with B. brongniartii (619). Most of the combinations, except for Decis, were compatible with Verticillium lecanii (972). M. anisopliae (1144) was very sensitive to all the formulations. Nuvacron and Stron were compatible with B. bassiana (1196), P. fumosoroseus (1200) and S. insectorum (1229). Marshal was compatible with B. bassiana 
(1196) and S. insectorum (1229), and Dipterex was compatible with P. fumosoroseus (1200). Two production methods and two culture media were evaluated for production of the fungi B. bassiana (1196), M. anisopliae (1189), S. insectorum (1229), P. fumosoroseus (1200) and V. lecanii (1200). The fungi P. fumosoroseus and B. bassiana were the most productive using the box method. In the tray method, B. bassiana was the most productive fungus. Between the production methods tested, $V$. lecanii was more productive in the tray method and P. fumosoroseus in the box method. Observations in Scanning Electronic Microscope LEO 435VP (SEM) revealed that, in general, all of the hyphomycetes had similar biological cycles on $L$. heveae, with adhesion, germination and beginning of the penetration within $24 \mathrm{~h}$, vegetative growth between 48 and $72 \mathrm{~h}$, and the extrusion and conidiogenesis of the pathogens by $96 \mathrm{~h}$. 


\section{INTRODUÇÃO}

A seringueira [Hevea brasiliensis (Willd. ex Adr. de Juss.) Muell-Arg.] é a principal fonte de borracha natural produzida no mundo. É o único produto natural que possui elasticidade, plasticidade, resistência ao desgaste, propriedade isolante de eletricidade, e impermeabilidade para líquidos e gases, sendo essencial como matériaprima para o transporte, indústria etc. A borracha sintética obtida do petróleo possui quase a mesma composição química da natural, porém suas propriedades físicas ficam restritas a alguns manufaturados.

O Brasil, apesar de ser o centro de origem da Hevea (Euphorbiacea), continua sendo grande importador de borracha natural. Em 1999, foram importadas 98 mil toneladas de borracha natural, para um consumo nacional estimado em 170 mil toneladas. Nesse mesmo ano, o Brasil atingiu a produção recorde de 70 mil toneladas.

As pesquisas de seringueira no Brasil têm dado ênfase às áreas de melhoramento genético e fitopatologia em detrimento da entomologia, razão pela qual, existem poucas informações disponíveis sobre artrópodes e seu controle. Em função dessa carência de informações sobre a espécie de praga, a utilização inadequada de pesticidas químicos, que nem sempre reduzem as populações das pragas a níveis economicamente aceitáveis, têm resultado em problemas sérios com resistência, contaminação pessoal e ambiental. Assim, há necessidade de pesquisas sobre o desenvolvimento de métodos alternativos de controle para as diversas pragas da seringueira.

Os problemas com pragas eram limitados a pequenos danos causados esporadicamente pela lagarta mandarová (Erinnys ello) e formigas cortadeiras, principalmente do gênero Atta spp. Atualmente, além de pragas de menor importância, como tripes, cochonilhas, gafanhotos, grilos, os maiores problemas nessa década de 90, 
destacando-se pelas perdas de produção que têm causado, são os ácaros e o percevejode-renda-da-seringueira (Benesi, 1999).

O percevejo-de-renda-da-seringueira, Leptopharsa heveae Drake \& Poor, 1935 (Hemiptera: Tingidae) está disseminado nas principais regiões produtoras de látex distribuídas nas regiões Norte, Centro-Oeste e Sudeste do Brasil.

O Manejo Integrado de Pragas encoraja a diminuição de pesticidas químicos e fornece várias opções de se controlar a praga harmoniosamente, para fazer com que esta permaneça em baixos níveis (Papacek \& Smith, 1994). O controle biológico está dentre as opções de controle de pragas preconizados pelo MIP, empregando a utilização de agentes biológicos para controle; como predadores, parasitóides e entomopatógenos.

A possibilidade de utilização de fungos para controle de insetos traz perspectivas positivas e animadoras para os heveicultores, pois, além da alta patogenicidade destes agentes, podem se beneficiar de algumas vantagens deste método de controle relacionadas por Alves (1998a), como a especificidade, capacidade de multiplicação e dispersão no ambiente, controle mais duradouro, possibilidade de associação com outros métodos de controle, possibilidade de utilização das mesmas máquinas convencionais para aplicação de defensivos químicos, não poluição do ambiente e o baixo risco de intoxicação para homens e animais.

O presente trabalho teve os seguintes objetivos: a) explorar as espécies de fungos entomopatogênicos associados ao percevejo-de-renda-da-seringueira nas regiões tradicionais de cultivo comercial e nativo da Hevea; b) selecionar isolados de fungos entomopatogênicos em condições de laboratório; c) estudar os métodos de multiplicação desses patógenos mais promissores; d) testar a compatibilidade dos fungos promissores aos produtos fitossanitários utilizados na cultura da seringueira. 


\section{REVISÃO DE LITERATURA}

\subsection{Hevea}

O gênero Hevea pertence à família Euphorbiaceae que compreende outros gêneros importantes de culturas tropicais, tais como Ricinus (mamona) e Manihot (mandioca). A classificação atual do gênero Hevea congrega 11 espécies, dentre as quais destaca-se a $H$. brasiliensis. A seringueira é uma espécie arbórea de crescimento rápido, apresentando grande capacidade de reciclagem de carbono, transformando-o em látex, celulose, madeira etc. Após a sua implantação, o seringal constitui um sistema estável, apresentando características de floresta tropical. É portanto, uma cultura nobre, que conserva o solo, melhora o meio ambiente, gera empregos e riquezas. A seringueira permanece viva e produtiva por longo tempo, além de representar mais uma cultura alternativa, permitindo a utilização das áreas degradadas ou imprestáveis para o cultivo de culturas anuais (IAC, 2001)

Em seringais recém-implantados, principalmente em pequenas propriedades, o uso da cultura intercalar pode ser uma alternativa para complementar a renda do produtor. A consorciação com culturas anuais deve ser feita no início do desenvolvimento do seringal, sendo que qualquer cultura pode ser utilizada nas entrelinhas da seringueira, desde que não hospedem pragas e doenças que possam infestar o seringal e a competição entre as duas espécies não prejudique o desenvolvimento da cultura principal. As vantagens mais atrativas quando se planeja a implantação de um sistema agroflorestal são a redução do período de imaturidade das plantas e a diminuição dos custos de implantação do seringal, devido a renda extra conseguida na mesma área de cultivo. Dependendo do desenvolvimento do seringal, até o terceiro ou quarto ano, existem condições de luminosidade nas entrelinhas, permitindo o cultivo de alguma cultura intercalar (May et al., 1999). 
$\mathrm{Na}$ Ásia, ao longo do final deste século têm-se buscado algumas alternativas para elevar a renda do produtor. A exploração da madeira tem sido a alternativa complementar mais importante, extraída quando o período produtivo das árvores se encerra (25 a 30 anos). Na Malásia, onde $70 \%$ da madeira utilizada vem da seringueira e outra parte tem sido exportada para o Japão para produção de móveis ao preço de US\$ $220,00 / \mathrm{m}^{3}$. Existe a possibilidade de extração de 130 a 180 toneladas de madeira/ha em um seringal no final do seu ciclo produtivo. Também pode-se produzir, em escala moderada, sementes e mel. A extração do óleo de sementes de seringueira vem apresentando grande potencial industrial, no entanto a sua utilização depende dos custos de mão-de-obra para a coleta e das condições de armazenamento (IAC, 2001).

\subsection{Tingidae}

Já foram registrados no mundo cerca de 275 animais, entre nematóides, insetos, ácaros, moluscos e mamíferos associados à seringueira e às plantas de cobertura, geralmente leguminosas, dos quais 218 são insetos e destes, 9,6\% são da Ordem Hemiptera (EMBRATER, 1983).

Nessa ordem de insetos, o gênero Leptopharsa Stal. é o que possui maior número de espécies dentro da família Tingidae, alcançando um total de 94. No Brasil ocorrem a maioria delas, ou seja cerca de 54 (Monte, 1940). Em um estudo sobre hospedeiros de tingídeos, Livingstone (1977) afirma que esses insetos são predominantemente monófagos, ocasionalmente oligófagos e raramente polífagos. Cerca de 33 famílias de plantas foram reportadas tendo somente uma espécie de tingídeo.

Em diversas culturas do Brasil esses insetos são considerados praga, como em mandioca na região Nordeste, o gênero Vatiga. No Ceará, Gargaphia lunulata, conhecido como "mosquito do maracujá" é uma das pragas mais importantes. No tomate, ocorre Corythaica cyathicollis (Gallo et al., 1988). Ulontingis spp. já foram observadas em goiabeira (Lima \& Raccha Filho, 1991; Hickel \& Ducroquet, 1993).

Em outros países como na Colômbia, na cultura do dendê, Gargaphia têm causados sérios prejuízos (Genty et al., 1975). Nos Estados Unidos, a segunda praga mais importante de azaléa é Stephanitis pyrioides (Neal Jr. \& Douglas, 1988). E em 
sempre-viva (Rosaceae) Neal Jr. \& Douglas, 1990 estudaram Corythuca cydoniae. Na Flórida, Hall (1991) constatou em cana-de-açúcar Leptodictya tabida

$\mathrm{Na}$ Europa, em cidades da França, Moulet (1989) relatou C. ciliata em

Platanus. O mesmo inseto foi observado também na mesma planta na Itália por Baseggio (1990) e na Espanha por Soria et al. (1991), onde estudaram sua disseminação que foi em torno de $70 \mathrm{~km} / \mathrm{ano}$.

$\mathrm{Na}$ heveicultura, destaca-se o percevejo-de-renda-da-seringueira, Leptopharsa heveae (Hemiptera: Tingidae) como único hospedeiro dessa cultura. Foi registrado pela primeira vez em 1935 em Boa Vista, RR e Rio Tapajós, PA, por Charles H.T. Townsend (Drake \& Poor, 1935). Esse inseto tornou-se praga dos seringais primeiramente no município de Mosqueiro-PA, em 1977, onde a infestação ocorreu em viveiros e seringais jovens de cinco anos de idade (Rodrigues, 1977). Na região Centro-Oeste, Kuffner (1986) citou L. heveae como praga da seringueira e que a infestação no Estado do Mato Grosso, na região de São José do Rio Claro, ocorreu principalmente nos meses de novembro e dezembro. Na região Sudeste, no Estado de São Paulo, onde segundo Martin \& Arruda (1993), estão concentradas as maiores regiões produtoras do país, Batista Filho et al (1995) observaram a presença deste inseto no município de BuritamaSP, nos clones PR 261 e GT 1.

\subsubsection{Prejuízos causados por $L$. heveae em seringueira}

Os prejuízos em seringueira foram calculados por Moreira (1985), comparando o desenvolvimento de plantas infestadas e não infestadas por L. heveae; o autor constatou que a infestação provoca uma redução de $28 \%$ no crescimento em altura e de 44,5\% no diâmetro do colo das plantas.

Em trabalhos desenvolvidos por Tanzini (1998), constatou-se que mudas infestadas com 2, 4 e 8 insetos/folíolo, comparadas com a testemunha, apresentaram redução de crescimento de 12, 60 e 64\%, respectivamente, sendo que a infestação de 2 insetos/folíolo não foi diferente, significativamente, da testemunha com 30 dias após a infestação. Em outro ensaio de avaliação de influência de produção com os clones IAN 
873, RRIM 527, PB 235 e GT 1, observou-se a redução média de 30\% na produção, em relação a área não atacada.

Nas regiões onde a seringueira renova a folhagem no período mais seco e mais frio do ano (áreas de "escape" às doenças foliares), esse percevejo provoca a senescência precoce ou queda anormal da folhagem, forçando a seringueira a renovar a folhagem em períodos quentes e úmidos, favoráveis ao ataque epidêmico de doenças que incidem somente em folhas jovens, como o mal-das-folhas (Microcyclus ulei) e a mancha aureolada (Thanatephorus cucumeris) (Junqueira et al,1987).

A capacidade de prejuízos desses insetos é tão grande que na Índia, Mishra \& Sen-Sarma (1986) estudaram a possibilidade do uso de tingídeos no controle de ervas daninhas como Lantana camara e Tectona grandis utilizando L. decora no controle da planta. Na África do Sul o Teleonemia scrupulosa, foi testado conjuntamente, e teve a capacidade de se estabelecer com outros insetos para o controle da L. camara (Cilliers \& Neser, 1991). Nos Estados Unidos, Pecora et al. (1992) estudaram possíveis hospedeiros do tingídeo Oncochila simplex, e concluíram ser um forte candidato para controle biológico de Euphorbia esula.

\subsubsection{Bioecologia}

A biologia do percevejo-de-renda-da-seringueira foi estudada por Tanzini (1996). Esta espécie efetua postura endofítica, apresenta fecundidade média de 89 ovos/fêmea, tendo uma postura diária média de 2,83 2,66 ovos/fêmea e um período de incubação médio de 12 dias. A duração dos períodos ninfais foi de 2,1;2,8; 3,4;3,3; 3,3 dias para os cinco ínstares, respectivamente; a longevidade dos adultos tenerais foi de 3,5 dias e dos adultos de 17 dias, no clone PB 235. Resultados semelhantes foram obtidos por Fonseca (2001), sendo que esses estudos foram mais detalhados utilizando quatro temperaturas com o clone RRIM 600.

Observou-se a ocorrência de L. heveae na cultura durante todo o ano, havendo sobreposições de gerações. Estudos de flutuação populacional foram conduzidos por Tanzini (1998) no clone GT 1 em Itiquira-MT em 1997. O menor nível populacional de ninfas foi de 0,3 insetos/folíolo no mês de abril, e o maior de 36 insetos/folíolo em 
outubro. Para adultos, o menor nível populacional foi de 0,3 adultos/folíolo em março, e o maior foi de 19 adultos/folíolo no mês de julho que foi o período de senescência da planta. Esse estágio do inseto ocorre, predominantemente, durante o período de inverno, não causando maiores danos devido as senilidade das folhas. Os maiores prejuízos na cultura foram observados em novembro quando a população chegou a 13 adultos/folíolo.

Batista Filho et al. (1998) estudaram a distribuição sazonal de L. heveae no clone PB 235 em Pindorama-SP. Observaram a ocorrência de ninfas e adultos durante quase o ano todo, com acentuada concentração entre os meses de dezembro a março, sendo que para ninfas, março foi o mês com a maior concentração, seguindo de dezembro e janeiro e, para adultos, os meses de dezembro, janeiro e fevereiro foram os de maior concentração. Esses resultados foram semelhantes aos obtidos por Fonseca (2001) em estudos no mesmo local. Em Mato Grosso, segundo Dall'Oglio et al. (1999) o acme populacional ocorreu na época chuvosa, logo após a senescência.

O hábito desse tingídeo, tanto de ninfas como de adultos, é de permanecer na página inferior de folhas de seringueiras jovens e adultas, sugando a seiva e destruindo o parênquima, dificultando assim, a função clorofiliana da planta e produzindo lesões que predispõem ao ataque de microrganismos (Carrera, 1973). Fonseca (2001) verificou que ninfas e adultos podem ser amostrados na parte externa do terço inferior das plantas, e ainda ocorre um aumento da densidade populacional de ninfas de L. heveae com o aumento da temperatura ambiental.

A resistência de clones de seringueira foi estudada por Tanzini (1996) que constatou a não-preferência para alimentação e oviposição nos clones Fx 4037, RO 38 e RO 46, sendo que o RO 46 apresentou também um efeito antibiótico. Também verificou que ocorreu preferência para alimentação e oviposição nos clones GT 1 e IAN 873, sendo que nesse primeiro clone as folhas mais novas são preferidas em relação às maduras para oviposição e alimentação. No clone RO 38, essa preferência para oviposição entre folhas maduras e novas, foi 28 vezes maior nas folhas novas o que explica o aumento da população no reenfolhamento. 


\subsubsection{Controle Químico}

O controle desse inseto foi possível com a utilização de produtos químicos como o monocrotofós a $0,4 \mathrm{~L} / \mathrm{ha}$, endosulfan a $0,8 \mathrm{~L} /$ ha e diafentiuron com $0,5 \mathrm{Kg} / \mathrm{ha}$, sendo a melhor eficiência dos dois primeiros produtos para adultos até 11 dias após a aplicação, e para ninfas todos apresentaram efeito choque, mas sem efeito residual devido à oviposição endofítica do inseto (Tanzini, 1999).

Vários métodos têm sido utilizados para controle dessa família de insetos como com C. ciliata, utilizando injeções com defensivos químicos no tronco; em Platanus, na Suíça, Mauri (1989) conseguiu reduzir grandemente os prejuízos na estação vegetativa, utilizando este processo. Na Itália, nesse mesmo hospedeiro do inseto também foi empregado o mesmo método utilizando acefato, com um controle satisfatório do tingídeo C. ciliata (Baseggio, 1990). Também, Zechini D’Aurelio et al. (1990), no mesmo país, estudaram esse método em plantas da mesma espécie com idade de 35 a 50 anos para o controle dessa praga obtendo resultados satisfatórios.

Outro método químico de controle de L. gibbicarina em palmeiras é a utilização sistemática de monocrotofós e dicrotofós, via raiz (Reyes et al., 1988).

Soetopo \& Iskandar (1986) constataram a elevada eficiência de inseticidas fenobucarb, isoprocarb e fenthion, via pulverização, em campos de pimenta (Piper nigrum) na Indonésia, para o controle de Diplogomphus hewitti.

\subsubsection{Controle Biológico}

Poucos estudos foram conduzidos até o momento, no sentido de se determinar o complexo de inimigos naturais do percevejo-de-renda-da-seringueira. A atuação de parasitóides, ainda não foi constatada para essa espécie de inseto no Brasil, mas existem registros como os de Livingstone (1977) que observou na Índia, ovos de tingídeos parasitados por Trichogramma e Anagrus spp. No trabalho de Yacoob et al. (1983) foram mencionados dois mimarídeos e três tricogramatídeos parasitando cerca de 20 tingídeos, sendo esses resultados confirmados posteriormente por Livingstone et al. (1985) e Livingstone \& Yacoob (1986). 
A presença de predadores foi notada por Tanzini (1997), quando registrou crisopídeos e sirfídeos nos seringais da Plantações E. Michelin, Itiquira-MT. Baseado nessas observações, Scomparin (1997) realizou levantamentos das espécies de crisopídeos que ocorrem no agroecossistema da cultura, encontrando 39 espécies, sendo as mais abundantes Chrysoperla externa, Cereaochrysa claveri, Cereaochrysa cincta e Cereaochrysa cubana. Ainda nesse trabalho, o autor observou que C. cincta foi a espécie que apresentou a característica de permanecer na copa das árvores sendo a mais abundante, com longevidade média de 54 dias e fecundidade de 353 ovos/fêmea. A capacidade de predação desse inseto foi de 124 adultos e 2812 ninfas do $1^{\circ}$ ínstar do percevejo-de-renda-da-seringueira durante o seu período larval.

Em outra pesquisa, Fonseca (2001) registrou a presença de artrópodes predadores de L. heveae como Araneae, Coccinellidae e Chrysopidae. Entre as famílias de aranhas, Dictynidae apresentou correlação positiva com a fase adulta do percevejode-renda-da-seringueira, o que pode ser uma rápida resposta numérica do predador às variações de densidade da presa.

Como uma das táticas de manejo dessa praga na seringueira, tem sido utilizado o fungo Sporothrix insectorum Hoog \& Evans, na tentativa de diminuir a infestação desta praga em diversos locais do Brasil. A possibilidade de utilização desse patógeno para o controle biológico de L. heveae foi notada, pela primeira vez, em Manaus-AM por Celestino Filho \& Magalhães (1986) em observações de campo, as quais revelaram que ninfas e adultos apresentaram infecção de 93 e 76\%, respectivamente.

O fungo $S$. insectorum mostrou-se eficiente agente no controle biológico do percevejo-de-renda-da-seringueira, mas sua eficiência está diretamente ligada às condições ambientais e a densidade populacional do inseto. Com a utilização deste patógeno o controle pode variar de $26 \%$ a $94 \%$ do período mais seco ao mais úmido, respectivamente, apresentando portanto, baixo índice de parasitismo e controle em períodos de umidade relativa baixa (Junqueira et al., 1988). Na cultura do dendê, Ordonez-Giraldo (1993) utilizou S. insectorum, isolado de L. heveae, e obteve eficiência de $73 \%$ em laboratório e $47 \%$ no campo, sobre L. gibbicarina. 
O isolamento e cultivo do fungo $S$. insectorum foi estudado, primeiramente, por Junqueira et al. (1987) sendo que o farelo de trigo foi considerado o melhor substrato para produção com menor custo. A produção de Sporothrix também pode ser feita utilizando o substrato de arroz ou quirera de milho, em sacos de prolipropileno de $350 \mathrm{~g}$ de capacidade, sendo autoclavados a $120^{\circ} \mathrm{C}$, com 1 atm por 25 minutos. Após a inoculação do fungo esses sacos foram mantidos em condições controladas de $25 \pm 2^{\circ} \mathrm{C}$ e $75 \pm 10 \%$ de UR por 6 dias, tempo suficiente para a completa miceliação do substrato com posterior rendimento de $1,5 \times 10^{9}$ conídios/g. Outro método de produção do fungo é a utilização de meios líquidos. Foram testados meios com leite de soja a $30 \%$ e caldo de feijão a $20 \%$, sendo que o primeiro foi superior 2,5 vezes ao substrato de arroz e o segundo não apresentou diferença significativa em relação ao meio sólido (Tanzini, 1999).

O desenvolvimento desse fungo foi testado por Tanzini (1998) nas temperaturas de 22, 26, 30 e $34^{\circ} \mathrm{C}$, medindo-se o diâmetro das colônias. Não apresentaram diferenças estatísticas entre as duas primeiras temperaturas, tendo uma redução de 29 e $81 \%$, respectivamente para 30 e $34^{\circ} \mathrm{C}$.

Considerando que a variabilidade genética entre isolados de uma mesma espécie de fungo pode resultar em diferentes níveis de mortalidade da praga, existe a possibilidade de seleção de isolados altamente virulentos. Muitos testes de patogenicidade têm sido realizados com Metarhizium anisopliae e Beauveria bassiana e evidenciaram a grande especificidade de determinados isolados para uma praga e a importância dos testes de seleção para utilização desses entomopatógenos em programas de controle microbiano.

Estas diferenças de patogenicidade e virulência entre isolados também foram documentadas para outros entomopatógenos, como Verticillium lecanii, Paecilomyces fumosoroseus e Nomuraea rileyi (Jackson et al., 1985; Maniania \& Fargues, 1992).

Na Itália, Girolami (1979) observou alta infecção de Beauveria bassiana em adultos de Corythuca ciliata (Say) (Tingidae), praga de árvores ornamentais do gênero Platanus, causando $100 \%$ de mortalidade. A possibilidade de utilização de outros fungos entomopatogênicos para controle de tingídeos pode ser baseada também em trabalhos 
como de Arzone \& Marletto-Ozino (1984); Marletto-Ozino \& Arzone (1985) e Tavella $\&$ Arzone (1987), que testaram nesse mesmo inseto, os fungos B. bassiana, V. lecanii e Paecilomyces farinosus, sendo o primeiro o mais virulento. 


\section{EPIZOOTIOLOGIA DE FUNGOS ENTOMOPATOGÊNICOS SOBRE Leptopharsa heveae}

\section{RESUMO}

Para o estudo da curva epizoótica de doenças sobre o percevejo-de-renda-daseringueira, efetuou-se a contagem de insetos vivos e mortos nas folhas de seringueira nos municípios de Pindorama-SP, no período de agosto de 1998 a julho de 2000 e em Itiquira-MT, de setembro de 1998 a junho de 2000. Na primeira localidade foram avaliadas as infestações do inseto nos clones RRIM 600, PR 107, PB 235 e GT 1, distribuídos ao acaso em blocos de seis árvores de cada clone e quatro plantas de bordadura de cada lado. Na segunda localidade, avaliou-se uma área plantada com o clone PB 260. Em ambos os locais, o experimento constou de cinco repetições, sendo cada uma composta por quatro árvores nas quais foram contadas cinco folhas, totalizando 100 folhas/clone. Em cada levantamento, foram coletadas amostras de insetos vivos para avaliação quanto a presença de algum tipo de patógeno. Foram coletados os dados climatológicos das estações situadas próximas ao locais de estudo para auxílio nas conclusões dos estudos epizootiológicos. Em Pindorama, constatou-se uma epizootia de Sporothrix sp. em ninfas do percevejo-de-renda-da-seringueira no início das avaliações. Em Itiquira, quando a infestação atingiu 56 ninfas e 18 adultos/folha verificou-se a ocorrência natural de Sporothrix sp., reduzindo a população a níveis muito baixos. 


\section{EPIZOOTIOLOGY OF ENTOMOPATHOGENIC FUNGI IN Leptopharsa heveae}

\section{SUMMARY}

Epizootic curves of diseases on the lacebug, were studied by counting live and dead insects on the rubber tree leaves in Pindorama-SP, from August 1998 to July 2000, and in Itiquira-MT, from September 1998 to June 2000. In Pindorama, the clones RRIM 600, PR 107, PB 235 and GT 1 were, distributed at random in blocks of six trees per clone and four border plants on each side. In Itiquira, the study area was planted with the clone PB 260. In both places, the experiment consisted of five repetitions, each consisting of four trees from which five leaves were counted, for a total of 100 leaves/clone. At each sampling, live insects were collected for evaluation of the presence pathogens. Climatological data were collected from the nearby stations. In Pindorama, an epizootic of Sporothrix sp. was observed in lacebug nymphs at the beginning of the evaluations. In Itiquira, when the lacebug infestation reached 56 nymphs and 18 adults/leaf, the natural occurrence of Sporothrix sp. was observed reducing the pest population to very low levels.

\subsection{Introdução}

A epizootiologia estuda os fatores que determinam ou controlam o desenvolvimento das doenças em populações de insetos em um determinado agroecossistema. Para o desenvolvimento de uma doença é necessário uma interação ecológica dinâmica entre hospedeiro e patógeno, influenciados diretamente pelo ambiente em que se encontram, resultando em modificações morfofisiológicas nos dois sistemas biológicos (Alves \& Lecuona, 1998).

Estudos de epizootiologia foram realizados observando a ação de Neozygites fumosa sobre o pseudococcídeo Phenacoccus manihoti em mandioca por Ru (1986), e 
notou-se que a umidade relativa e a temperatura afetaram a disseminação da doença. Dando seqüência a esse trabalho, Ru \& Iziquel (1990) observaram que a doença apresentou duas fases de disseminação. $\mathrm{Na}$ fase inicial de implantação houve uma correlação com o tamanho e estrutura das colônias, enquanto na segunda fase da epizootia foi correlacionada com a frequiência de chuvas, sendo favorável com umidade acima de $90 \%$, pelo menos durante 5 horas.

Nomuraea rileyi foi observado causando epizootia em populações de Helicoverpa armigera em culturas de tomate, feijão e ervilha (Gopalakrishnan \& Narayanan, 1989). Weseloh \& Andreadis (1992) estudaram a prevalência da doença causada pelo fungo Entomophaga maimaiga em Lymantria dispar.

Morris et al. (1996) estudaram a influência de Zoophthora phytonomi sobre curculionídeos em condições de campo na cultura da alfafa. E em afídeos, Steinkraus \& Rosenheim (1995) avaliaram os fatores biológicos que influenciaram na relação de Neozygites fresenii e Aphis gossypii.

Em seringueira, foi observada uma epizootia sobre Calacarus heveae (Acari : Eriophyidae) de Hirsutella thompsonii por Tanzini et al. (2000). As condições favoráveis à epizootia foram as altas infestações do ácaro nos clones PB 235, PB 260, PB 217, GT 1 e RRIM 600, que ocorreram de fevereiro a maio, associada às temperaturas que variam de 22 a $25^{\circ} \mathrm{C}$ e chuvas de 76 a $116 \mathrm{~mm}$ durante 5 a 18 dias. Nessas condições a infecção pelo fungo atingiu $100 \%$ de mortalidade dos ácaros.

Sobre o percevejo-de-renda-da-seringueira foi relatado por Celestino Filho \& Magalhães (1986), a ocorrência de Sporothrix insectorum, sendo isolado e constatado a eficiência sobre ninfas de $93 \%$ e $76 \%$ sobre adultos.

Existem poucos estudos de epizootiologia, principalmente com pragas da seringueira e seus entomopatógenos. Assim, o objetivo deste estudo foi averiguar se existe uma ação natural de doenças em $L$. heveae e correlacioná-las com as condições climáticas, visando um controle mais eficiente e racional da praga. 


\subsection{Material e Métodos}

Para o estudo da curva epizoótica de doenças sobre o percevejo-de-renda-daseringueira, iniciou-se a contagem de insetos vivos e mortos nas folhas de seringueira nos municípios de Pindorama-SP, na Estação Experimental do Instituto Agronômico de Campinas, no período de agosto de 1998 a julho de 2000. Trabalho semelhante foi realizado em Itiquira-MT, na Fazenda da Plantações E. Michelin, de setembro de 1998 a junho de 2000.

$\mathrm{Na}$ primeira localidade foram avaliadas as infestações do inseto nos clones RRIM 600, PR 107, PB 235 e GT 1, distribuídos ao acaso em blocos de seis árvores de cada clone e quatro plantas de bordadura de cada lado, com espaçamento de $8 \times 2,5 \mathrm{~m}$. A idade desse seringal no início do levantamento era de seis anos e ainda não encontravase em explotação. Na segunda localidade, avaliou-se uma área plantada com o clone PB 260, com o mesmo espaçamento anterior e com 8 anos de plantio, também sem ter entrado em sangria. Foi realizada uma aplicação de inseticida em 29 de setembro de 1998 quando a população estava em ascendência.

Em ambos os locais, o experimento constou de cinco repetições, sendo cada uma composta por quatro árvores nas quais foram contadas cinco folhas, totalizando 100 folhas/clone. Essa mesma metodologia foi utilizada por Junqueira et al. (1988).

As folhas foram retiradas com auxílio de uma tesoura presa numa haste de alumínio ou abaixando os galhos para contagem direta de ninfas e adultos do inseto. As avaliações foram realizadas mensalmente.

Em cada levantamento, foram coletadas amostras de insetos vivos para avaliação quanto a presença de algum tipo de patógeno. Os insetos foram mortos em freezer $\left(-20^{\circ} \mathrm{C}\right)$ e lavados em álcool $70 \%$ por 10 segundos e posteriormente em água destilada, durante o mesmo período, para descontaminação externa. Em seguida, os indivíduos foram transferidos para placas plásticas de cultura de tecido, onde permaneceram acondicionados num recipiente fechado, revestido com uma espuma úmida e mantidos em câmara climatizada a $26 \pm 0,5^{\circ} \mathrm{C}$ e fotofase de 12 horas. Após cinco dias foram feitas as avaliações da presença de fungos. 
Foram coletados os dados climatológicos das estações locais situadas a aproximadamente 3 e $10 \mathrm{~km}$, respectivamente em Pindorama e Itiquira, para auxílio nas conclusões dos estudos epizootiológicos.

\subsection{Resultados e Discussão}

No período de agosto de 1998 a julho de 2000 a presença do fungo sobre ninfas de L. heveae (Figura 1), foi observada do primeiro ao terceiro mês de avaliação, não se registrando mais a ocorrência do patógeno até julho de 2000. De agosto a setembro de 1998, observou-se uma redução da população de 96, 60, 93 e 64\%, respectivamente, para os clones RRIM 600, PR 107, PB 235 e GT 1.

Observou-se que com o início das chuvas (agosto/98) houve a ocorrência do patógeno e a constatação de insetos contaminados (Figura 2). Essa mortalidade pode estar ligada a diferença da densidade foliar de cada clone. Assim, quanto mais densa a folhagem, ocorre a formação de um microclima favorável para o desenvolvimento do fungo. Esse mesmo fato foi observado por Junqueira et al. (1999) em Manaus, com clones obtidos de Hevea pauciflora que possuem hábito fenológico perenifolium e as copas mais densas.

Após a reenfolhação em agosto de 1999, houve um aumento populacional, chegando a um ponto máximo em novembro desse ano com aproximadamente 2,0; 3,0; 4,0 e 8,0 ninfas/folha, nos clones RRIM 600, PR 107, PB 235 e GT 1, respectivamente.

Segundo Alves \& Lecuona (1998), apenas a densidade elevada de uma população de insetos não leva à ocorrência de uma doença. Outros fatores, como suscetibilidade, atual ou momentânea da população, hábitos do inseto, características do patógeno, potencial de inóculo e condições de clima, são determinantes para o desencadeamento da epizootia. De acordo com este autor, a competição pelo alimento pode levar o inseto a um estresse de alimentação, o que normalmente, resulta em maior 

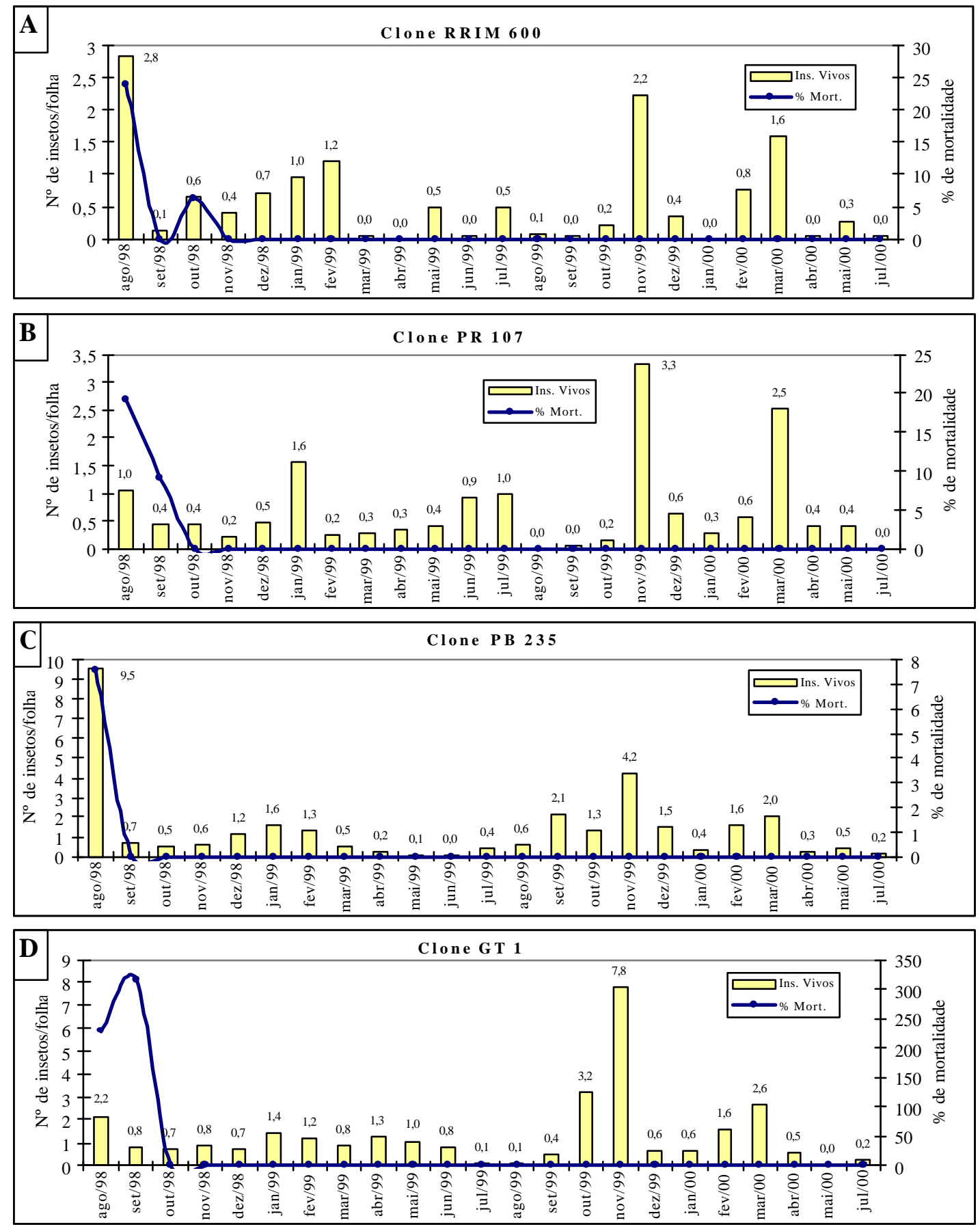

Figuras 1- Número de ninfas de Leptopharsa heveae/folha de seringueira e porcentagem de mortalidade causada por fungos nos clones RRIM 600, PR 107, PB 235 e GT 1 (Pindorama-SP, 2000). 

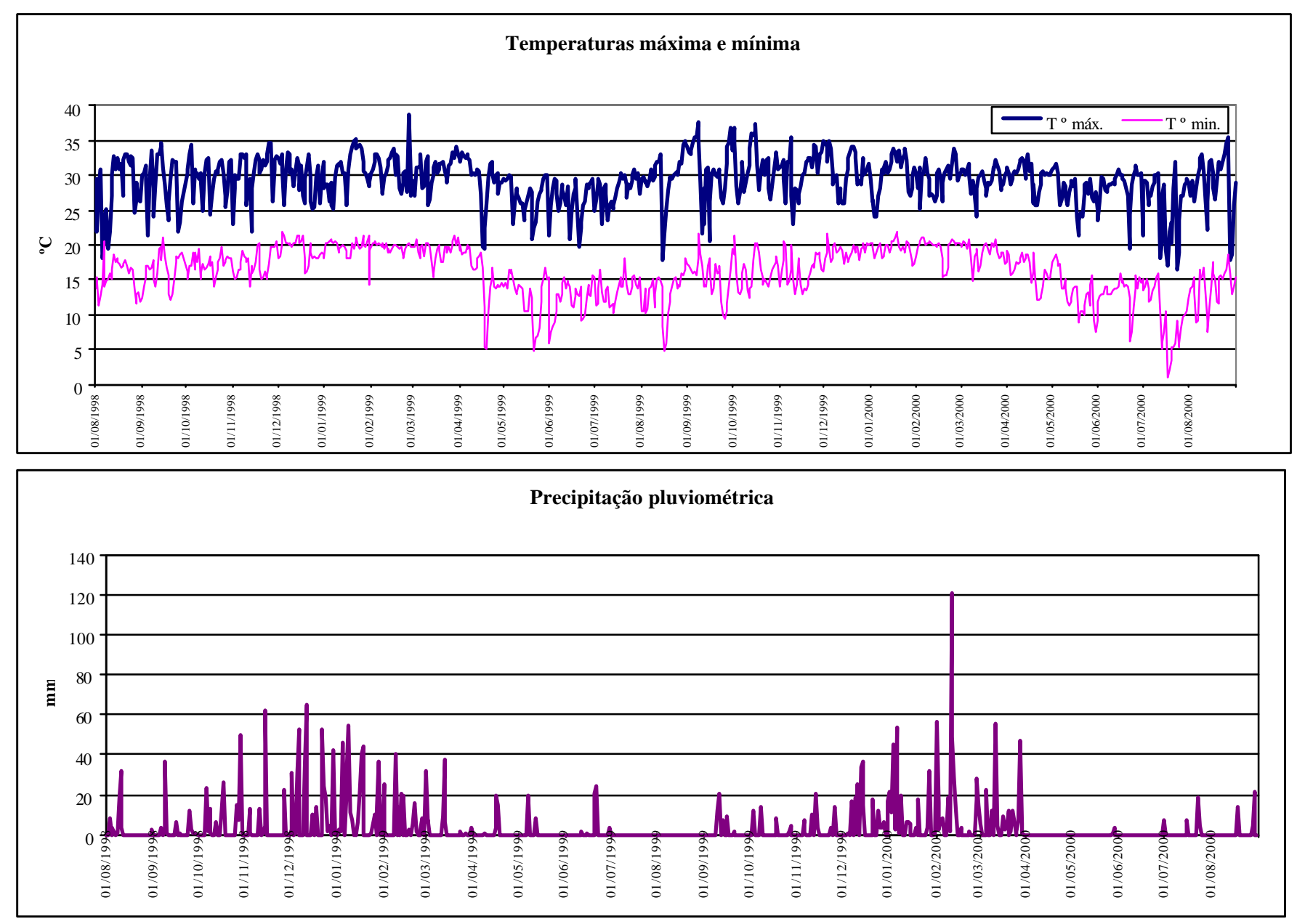

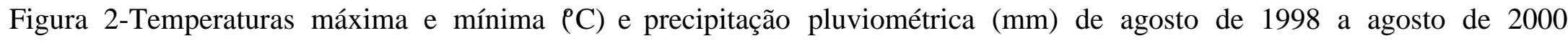
(Pindorama-SP,2000). 
suscetibilidade do mesmo. Essa baixa incidência da doença sobre ninfas do percevejo pode ser atribuída, principalmente, ao baixo potencial de inóculo existente nas áreas amostradas.

A maior população de ninfas do percevejo-de-renda-da-seringueira ocorre no período de outubro a maio, quando esses causam maiores prejuízos a cultura. No período avaliado, com exceção do clone RRIM 600, os outros três clones foram muito mais infestados no biênio 1999/2000 comparando-se com 1998/1999. Numa análise dos dados climatológicos em 2000, observou-se que choveu cerca de $240 \mathrm{~mm}$ a menos que no mesmo período em 1999, o que pode ter sido um fator que contribuiu para o aumento dessa população (Figura 2).

A infecção de insetos adultos foi observada em 1998, somente no clone GT 1. Esse fato pode ter sido devido a remanescência de folhas do ano anterior, pois esse clone apresentou uma senescência desuniforme, tendo folhas novas e antigas ao mesmo tempo, o que não aconteceu com os outros três clones estudados (Figura 3).

No clone PB 235, em fevereiro de 2000, foi encontrado um inseto morto por um fungo da ordem Entomophthorales, podendo-se observar a fixação através de rizóides e abertura das asas, o que facilita a ejeção dos conídios originados na região intersegmental do abdome (Figura 4).

Esse grupo de fungo tem uma grande importância no controle natural de diversas espécies de artrópodos, pela ocorrência de epizootias em condições de campo e pela alta velocidade com que atuam e reduzem as populações das pragas. De modo geral, os fatores importantes para que ocorra esse tipo de patógeno são: umidade elevada, próxima a 100\%, temperatura de 16 a $27^{\circ} \mathrm{C}$, densidade do hospedeiro, que deve ser mínima, capaz de gerar os focos primários e secundários, e presença de esporos em repouso no solo distribuídos na área de ocorrência do hospedeiro (Alves, 1998b). A maioria desses fatores foram observados na época em que foi encontrado o inseto contaminado. No entanto, a ocorrência desse entomopatógeno, não foi suficiente para manter a população de percevejos abaixo do nível de danos econômicos. 

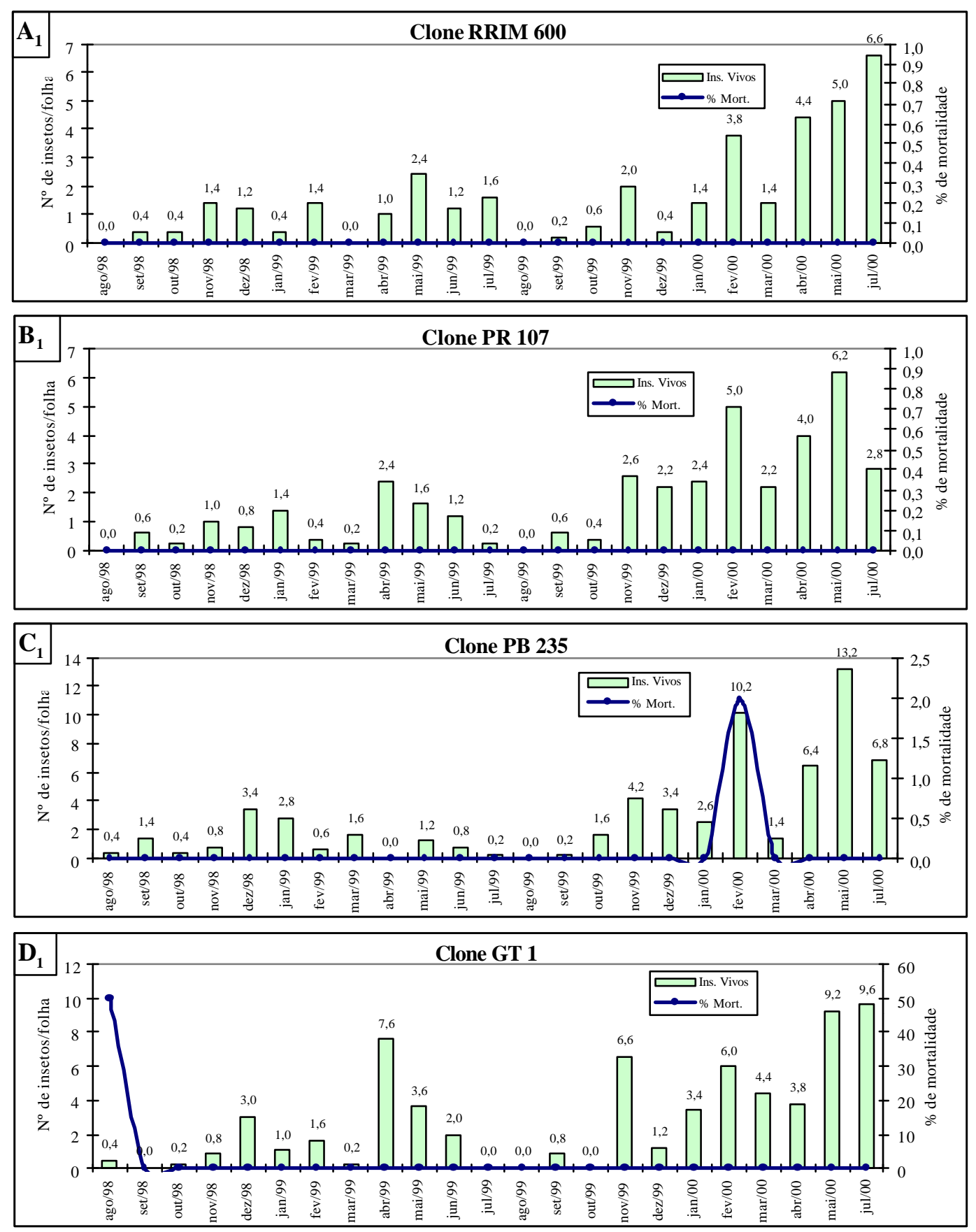

Figura 3- Número de adultos de Leptopharsa heveae/folha de seringueira e porcentagem de mortalidade causada por fungos nos clones RRIM 600, PR 107, PB 235 e GT 1 (Pindorama-SP, 2000). 


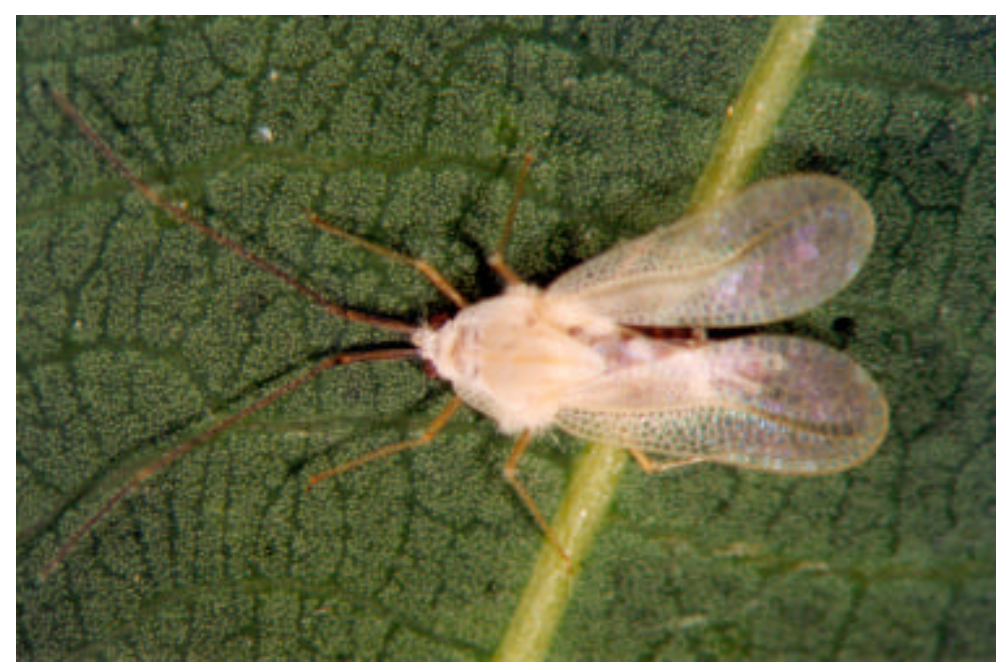

Figura 4- Leptopharsa heveae contaminado com fungo da ordem Entomophthorales (Pindorama-SP, 2000).

Assim, no último biênio avaliado, observou-se o aumento da população de adultos em todos os clones estudados, chegando a uma média máxima de 5 a 13 adultos/folha em maio de 2000 (Figura 3), não sendo encontrados insetos contaminados por outros fungos em nenhum dos clones avaliados. Com esse nível de infestação, esperava-se a ocorrência enzoótica de fungos, principalmente Sporothrix sp. Portanto, esse aumento da infestação, pode ser devido a ausência de entomopatógenos na área.

Comparando-se o período de outubro a maio dos dois biênios, constatou-se um aumento da ordem de 2,0;3,0;4,0 e 2,0 vezes da população de adultos para os clones RRIM 600, PR 107, PB 235 e GT 1 de 1999/2000 em comparação a 1998/1999. Esse fato pode estar também ligado a ausência de chuva a partir de abril de 2000 (Figura 2). Pode-se observar que no período avaliado, tanto para ninfas como para adultos de L. heveae, a doença apresentou-se no primeiro biênio como epizoótica, ou seja, ocorreu esporadicamente, e provocou grandes variações na prevalência, ou seja, no número total de insetos afetados pelo patógeno em um determinado tempo e na incidência da doença, definida pelo número de casos novos da doença na população de insetos em um determinado período.

O maior nível populacional foi observado no clone GT 1, seguido de PB 235, PR 107 e RRIM 600. Em 1999, com exceção do PB 235, houve um aumento da população nos meses de abril a junho, reduzindo a praticamente zero nos meses seguintes de senescência 
do seringal, fato inverso observado por Tanzini (1998), quando nesses meses observou uma média de 56 adultos/folha. Em dezembro houve tendência de elevação do número de insetos vivos, coincidindo com o aumento das chuvas e da disponibilidade de folhas novas (Figura 2). Tanzini (1996) constatou que esse inseto apresentou duas vezes mais preferência por alimentação no clone GT 1 com folhas novas comparadas às velhas e 28 vezes mais oviposição nessas folhas novas, o que explica o aumento da infestação do inseto nesses meses.

O fato de não ter sido observado inseto contaminado no ano de 1999, pode estar correlacionado com as condições climáticas que afetaram a senescência do seringal, causando desfolha total nos quatro clones. Esse fato não ocorreu em 1998, quando em outubro o clone GT1 ainda permanecia enfolhado. Possivelmente, por essa razão, o número de insetos contaminados foi maior nos primeiros meses de avaliação desse clone, em decorrência da maior fonte de inóculo remanescente do ano anterior, devido a permanência da folhagem que, dessa forma, garantiu a sobrevivência do fungo no seringal.

A porcentagem de insetos contaminados desde a senescência completa manteve-se baixa, talvez pela falta de focos primários da doença, que segundo Alves (1998b), são necessários para o início do desenvolvimento das doenças, e são formados devido a imigração de insetos doentes ou a partir de estruturas dos patógenos, trazidas pelo vento, água, pássaros, insetos parasitos e predadores e outros animais. Podem também ter origem nas estruturas do patógeno que permanecem no solo, em cadáveres de insetos e nas plantas.

No caso da ocorrência de Entomophthorales no percevejo-de-renda-da-seringueira, esta pode ser classificada como sendo de natureza ocasional já que nos meses anteriores e no período seguinte, o fungo não foi observado.

Em Itiquira, nas primeiras avaliações, antes de sofrer aplicação do inseticida methomyl (Lannate), quando a população estava com 21 ninfas e 11 adultos/folha, foi encontrado um inseto contaminado, e mesmo após a aplicação, quando a população aumentou para 10 ninfas e 5 adultos/folha, foi encontrado um e dois insetos contaminados, respectivamente, para as avaliações de 15/12/98 e 04/01/99, tendo nos meses seguintes uma redução da população, mantendo-se até o período de senescência, quando essa chegou a níveis próximos de zero, provavelmente pela dispersão para outros clones que mantém mais folhas nesse período. Nos meses seguintes houve uma tendência de aumento da infestação 
de insetos, provavelmente pela maior oviposição de adultos e uma disponibilidade maior de folhas novas, fato já observado por Tanzini (1998) quando a população atingiu 37 ninfas/folha em outubro de 1996 no mesmo local (Figura 5).

Em setembro de 1998, quando ocorreu a pulverização da área, houve uma diminuição da população de $89 \%$ de ninfas e $73 \%$ de adultos, e passou para 2 ninfas/folha (12 dias após a aplicação) e 3 adultos/folha. A população manteve-se alta de acordo com a classificação proposta por Tanzini (1997). Isso ocorreu, provavelmente, devido a diminuição de inimigos naturais, como consequência de um produto não seletivo. A ação de predadores sobre L. heveae, foi citada por Tanzini (1996) e Scomparin (1996), sendo que esse último autor avaliou a capacidade de predação de crisopídeos, chegando a 124 adultos e 2812 ninfas do $1^{\circ}$ ínstar do percevejo-de-renda-da-seringueira.

Na redução da população na avaliação de 15/02/99, chegando a 0,5 ninfa e 2 adultos/folha, até o final do período de avaliação de 1999, não foram observados mais insetos contaminados. Esses resultados foram semelhante aos de Pindorama, provavelmente pela mesma hipótese de falta de umidade no período para ocorrência natural da doença.

A partir do reenfolhamento das plantas que ocorreu em setembro de 1999, houve um aumento da população do inseto, chegando a uma média de 73 ninfas e 18 adultos/folha em dezembro de 1999. Com essa alta densidade de insetos, temperatura variando de 17 a $35^{\circ} \mathrm{C}$ e precipitação acumulada de $852 \mathrm{~mm}$ de dezembro de 1999 a março de 2000, ocorreu a contaminação tanto de ninfas como adultos de L. heveae. A partir de janeiro de 2000, a população de ninfas chegou a 55 insetos contaminados e de 12 adultos/folha, reduzindo drasticamente a população (Figura 5).

Uma outra hipótese para explicar a ocorrência dessa epizootia, são as aplicações anuais de S. insectorum desde 1994 nesse local. Essas aplicações contribuem para a formação de focos primários, essenciais para o desencadeamento da doença em Itiquira, o que não ocorreu em Pindorama, onde o fungo não havia sido aplicado nos últimos anos.

A redução que ocorreu de 23 de dezembro de 1999 a 19 de janeiro de 2000, de 88 e $86 \%$, respectivamente para ninfas e adultos do percevejo-de-renda-da-seringueira, são semelhantes às porcentagens de insetos contaminados de 93 e 76\%, observados por Celestino Filho \& Magalhães (1986) em Manaus- AM. 

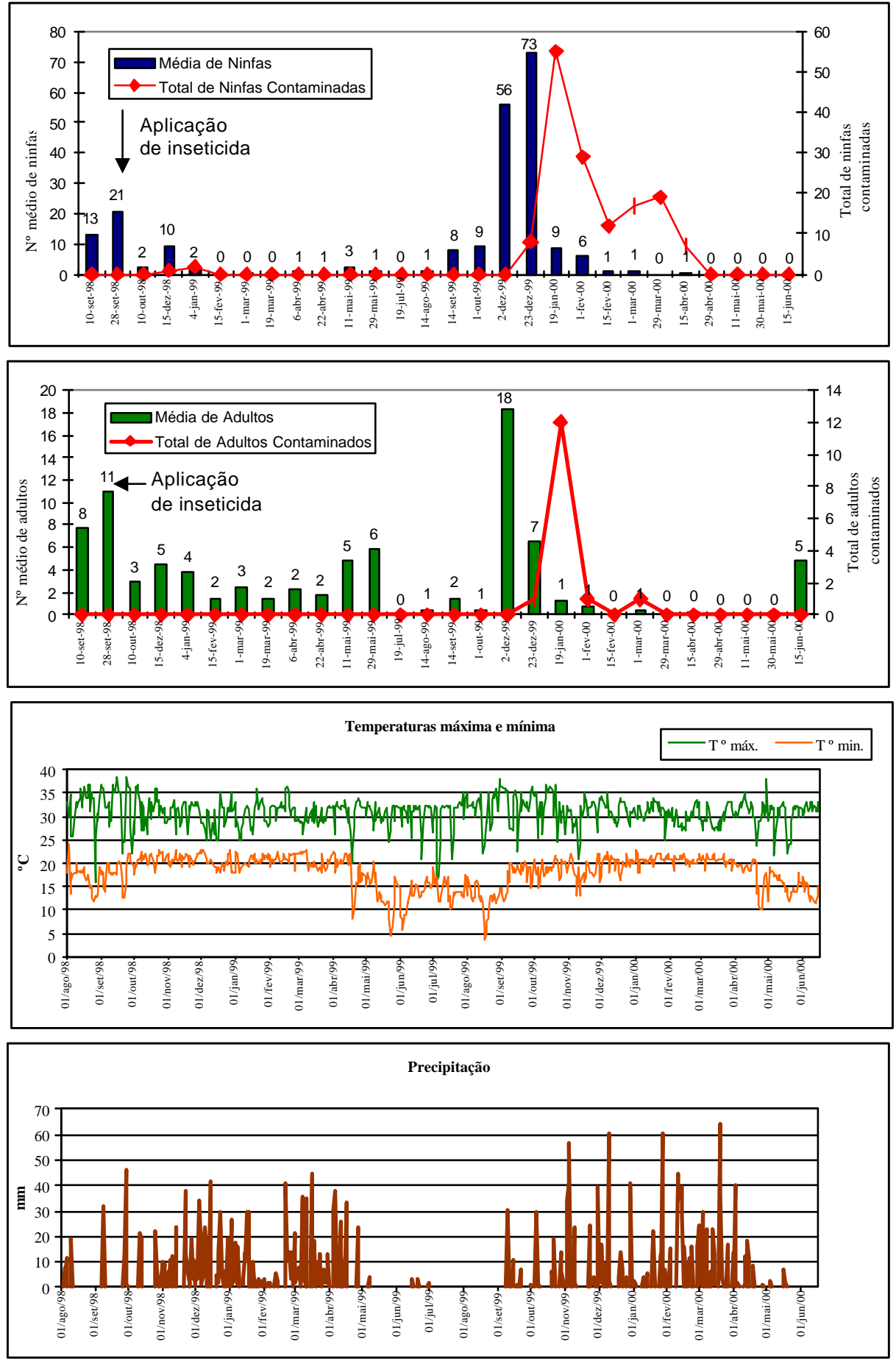

Figura 5- Número médio de ninfas e adultos de Leptopharsa heveae, total de insetos contaminados por fungos e temperaturas máxima e mínima de agosto de 1998 a julho de 2000 (Itiquira- MT, 2000). 


\subsection{Conclusões}

- Nos estudos de epizootiologia de fungos sobre o percevejo-de-renda-daseringueira, durante dois anos em Pindorama-SP, ocorreu uma epizootia de Sporothrix sp. nos meses de agosto e setembro de 1998 nos clones RRIM 600, PR 107, PB 235 e GT 1.

- O fungo Sporothrix sp. pode colonizar o percevejo-de-renda-da-seringueira mesmo após a aplicação do produto Lannate (methomyl).

- A ocorrência de Sporothrix sp. inicia-se a partir da ocorrência da elevada densidade populacional da praga (56 ninfas e 18 adultos/folha). 


\section{SELEÇÃO DE ISOLADOS DE FUNGOS ENTOMOPATOGÊNICOS VISANDO AO CONTROLE DE Leptopharsa heveae}

\section{RESUMO}

Avaliou-se a patogenicidade de 1 isolado de Aschersonia aleyrodis, 13 isolados de Beauveria spp., 5 de Hirsutella spp., 20 de Metarhizium anisopliae, 2 de Nomuraea rileyi, 7 de Paecilomyces spp., 7 de Sporothrix insectorum, 1 de Trichoderma sp. e 4 de Verticillium lecanii em condições de laboratório sobre ninfas do quarto ínstar de Leptopharsa heveae, praga da seringueira (Hevea brasiliensis, Euphorbiaceae). As ninfas (50 por tratamento) foram transferidas para discos de $5 \mathrm{~cm}$ de diâmetro. Sobre elas foram aplicados $0,2 \mu \mathrm{L} / \mathrm{cm}^{2}$ de suspensão de conídios na concentração de $1 \times 10^{8}$ usando-se Torre de Potter. As folhas foram mantidas sob a temperatura de $26 \pm 0,5^{\circ} \mathrm{C}$; $80 \%$ UR e $12 \mathrm{~h}$ de fotofase por 4 dias. Os fungos $H$. thompsonii, A. aleyrodis, $N$. rileyi e V. lecanii causaram mortalidades entre 23 e $50 \%$ sendo considerados pouco patogênicos. Beauveria spp., M. anisopliae, S. insectorum, Paecilomyces spp. e V. lecanii apresentaram grande variação na patogenicidade, sendo que os melhores isolados foram B. bassiana (619 e 1196) com 56 e 84\% de mortalidade com 3 dias após a inoculação, M. anisopliae (1144 e 1104) ambos com 90\%, S. insectorum (1229) com 92\% e $P$. fumosoroseus (1200) com 100\%. Trichoderma sp. um fungo fitopatogênico, depois de quatro dias da inoculação causou $78 \%$ de mortalidade. 


\section{SELECTION OF ENTOMOPATOGENIC FUNGAL ISOLATES FOR CONTROL OF Leptopharsa heveae}

\section{SUMMARY}

The patogenicities of the 1 isolate of Aschersonia aleyrodis, 13 isolates of Beauveria spp., 5 of Hirsutella spp., 20 of Metarhizium anisopliae, 2 of Nomuraea rileyi, 7 of Paecilomyces spp, 7 of Sporothrix insectorum, 1 of Trichoderma sp. and 4 of Verticillium lecanii were evaluated under laboratory conditions against nymphs of Leptopharsa heveae, a pest of rubber tree (Hevea brasiliensis, Euphorbiaceae). Conidial suspensions $\left(0,2 \mu \mathrm{L} / \mathrm{cm}^{2} / 1 \times 10^{8}\right)$ of the isolates were applied using Potter Tower, on to $5 \mathrm{~cm}$ Hevea brasiliensis leaf disks with 50 nymphs/treatment. Insects were maintained under controlled conditions at $26 \pm 0.5^{\circ} \mathrm{C} ; 80 \% \mathrm{RH}$ and 12:12 Light:Dark cycles for four days. The fungi $H$. thompsonii, A. aleyrodis, $V$. lecanii and $N$. rileyi caused mortality between 23 and 50\% and were considered of low pathogenicity. For Beauveria spp., M. anisopliae, S. insectorum, Paecilomyces spp. and V. lecanii great variation was observed in the patogenicities of isolates. The best isolates were Beauveria bassiana 619 and 1196 with 56 and 84\% mortality 3 days after inoculation, M. anisopliae 1144 and 1104 both with 90\%, S. insectorum 1229 with $92 \%$ and P. fumosoroseus 1200 with $100 \%$ mortality. Trichoderma sp., a phytopathogenic fungus, caused $78 \%$ of mortality 4 days after inoculation.

\subsection{Introdução}

A seleção de isolados de fungos entomopatogênicos é de extrema importância para o uso desses entomopatógenos no controle de pragas. Esse procedimento é sempre possível já que existe uma grande variabilidade genética, podendo ser considerada uma 
das principais vantagens da utilização desses patógenos como agentes de controle de artrópodes (Alves, 1998b).

Diversos estudos já foram realizados visando a seleção de isolados altamente patogênicos de $M$. anisopliae e B. bassiana para o controle de pragas. Assim, são importantes os trabalhos visando ao controle de cupins (Almeida et al., 1997), pragas de grãos armazenados (Moino Jr. \& Alves, 1997), ácaro (Tamai, 1997), baratas (Vieira et al., 1993; Manzini et al., 1998) e tripes (Lopes, 1999). Os resultados dessas pesquisas evidenciaram a grande variabilidade genética desses entomopatógenos sendo possível a seleção de isolados altamente patogênicos para determinadas pragas.

Poucos estudos têm sido desenvolvidos buscando o controle biológico de percevejos no Brasil. Um dos trabalhos desenvolvidos nessa área foi com Triatoma infestans, vetor da doença de Chagas, onde foram testados 23 isolados de B. bassiana e 13 de M. anisopliae, observando uma variação da mortalidade de 18 a 98\% (Luz et al., 1998). Outra pesquisa foi sobre percevejos que ocorrem na cultura da soja. Neste trabalho avaliaram-se a eficiência de isolados de M. anisopliae e B. bassiana para o possível desenvolvimento de um inseticida microbiano para essas pragas (Sosa Gomez \& Moscardi, 1998).

$\mathrm{Na}$ Colômbia, já foi utilizado $S$. insectorum, isolado de $L$. heveae, para o controle de Leptopharsa gibbicarina em palmeira por Ordonez-Giraldo (1993). Em condições de laboratório esse fungo causou $73 \%$ de mortalidade e em campo chegou a 47\% de eficiência. Também nessa mesma cultura, Mariau (1994) citou que Beauveria sp. pode ser uma alternativa de controle para L. gibbicarina e Pleseobyrsa bicincta.

O fungo $S$. insectorum foi testado por Leite et al. (1998) sobre ninfas e adultos de Stephanitis pyrioides usando uma suspensão com $2 \times 10^{6}$ conídios $/ \mathrm{mL}$, causando $40 \%$ de mortalidade de adultos e 13\% de ninfas. Esse mesmo fungo foi testado por Oliveira et al. (1998) sobre o tingídeo Vatiga illudens os quais relataram ser um bom agente no controle microbiano desse inseto.

No tingídeo Corythuca ciliata já foram testados outros fungos como $B$. bassiana, V. lecanii e $P$. farinosus, em plátano, sendo que os três patógenos mostraram 
alta infectividade com seis dias após inoculação (Arzone \& Marletto-Ozino, 1984; Marletto-Ozino \& Arzone, 1985 e Tavella \& Arzone, 1987).

A cultura da seringueira que apresenta características favoráveis como temperatura mais amena sob sua copa, alta umidade e proteção contra a radiação solar, entre outros, favorece a utilização de entomopatógenos. Atualmente, para o controle dessa praga, é utilizado Sporothrix sp. altamente dependente da umidade e temperatura do agroecossistema considerado.

Assim, o objetivo deste estudo foi selecionar isolados de fungos entomopatogênicos altamente patogênicos para o controle de $L$. heveae, considerada uma das principais pragas da cultura da seringueira.

\subsection{Material e Métodos}

Nos bioensaios foram utilizados isolados de Aschersonia aleyrodis, Beauveria spp., Hirsutella spp., Metarhizium anisopliae, Nomuraea rileyi, Paecilomyces spp., Sporothrix insectorum, Trichoderma sp. e Verticillium sp., preservados no Banco de Patógenos do Laboratório de Patologia e Controle Microbiano de Insetos do Setor de Entomologia da ESALQ/USP. Foram testados 60 isolados procedentes de insetos, ácaro e solos coletados em diversas regiões (Tabela 1).

Tabela 1. Isolados de fungos entomopatogênicos utilizados nos bioensaios com ninfas de Leptopharsa heveae (Piracicaba-SP, 1999).

\begin{tabular}{llll}
\hline Isolado & \multicolumn{1}{c}{ Patógeno } & \multicolumn{1}{c}{ Procedência } & \multicolumn{1}{c}{ Hospedeiro } \\
\hline 1216 & Aschersonia aleyrodis & Guaíra-SP & Bemisia tabaci \\
PL 63 & Beauveria bassiana & Piracicaba-SP & Atta sp. \\
307 & Beauveria bassiana & Araras-SP & Diatraea saccharalis
\end{tabular}


Tabela 1. Isolados de fungos entomopatogênicos utilizados nos bioensaios com ninfas de Leptopharsa heveae (Piracicaba-SP, 1999).

\begin{tabular}{|c|c|c|c|}
\hline Isolado & Patógeno & Procedência & Hospedeiro \\
\hline 447 & Beauveria bassiana & Cuiabá-MT & Solenopsis invicta \\
\hline 457 & Beauveria bassiana & Goiânia-GO & Euschistus heros \\
\hline 489 & Beauveria bassiana & Desconhecida & Hemileucidae \\
\hline 494 & Beauveria bassiana & Piracicaba-SP & Dorcacerus barbatus \\
\hline 868 & Beauveria bassiana & Goiânia-GO & Formicidae \\
\hline 908 & Beauveria bassiana & Cuiabá-MT & Solenopsis sp. \\
\hline 969 & Beauveria bassiana & Piracicaba-SP & Blatella germanica \\
\hline 1196 & Beauveria bassiana & Corumbá-MS & Solo \\
\hline 1219 & Beauveria bassiana & Botucatu-SP & Carabidae \\
\hline 1233 & Beauveria bassiana & Piracicaba-SP & Chrysomelidae \\
\hline 619 & Beauveria brongniartii & Goiânia-GO & Pentatomidae \\
\hline 1221 & Hirsutella thompsonii & Itiquira-MT & Calacarus heveae \\
\hline 1234 & Hirsutella verticilioides & Brasília-DF & Leptopharsa heveae \\
\hline 1235 & Hirsutella verticilioides & Brasília-DF & Leptopharsa heveae \\
\hline 1236 & Hirsutella verticilioides & Brasília-DF & Leptopharsa heveae \\
\hline 1237 & Hirsutella verticilioides & Brasília-DF & Leptopharsa heveae \\
\hline E9 & Metarhizium anisopliae & Boca da Mata-AL & Mahanarva posticata \\
\hline RJD & Metarhizium anisopliae & Desconhecido & Desconhecido \\
\hline E6 & Metarhizium anisopliae & Pernambuco & Diatraea saccharalis \\
\hline RJC & Metarhizium anisopliae & Desconhecido & Desconhecido \\
\hline 798 & Metarhizium anisopliae & Cuiabá-MT & Solenopsis invicta \\
\hline 860 & Metarhizium anisopliae & Piracicaba-SP & Macrospis sp. \\
\hline 865 & Metarhizium anisopliae & Goiânia-GO & Homoptera \\
\hline 866 & Metarhizium anisopliae & Goiânia-GO & Atta sp. \\
\hline 867 & Metarhizium anisopliae & Goiânia-GO & Atta sp. \\
\hline 935 & Metarhizium anisopliae & Itabúna-BA & Diatraea saccharalis \\
\hline
\end{tabular}


Tabela 1. Isolados de fungos entomopatogênicos utilizados nos bioensaios com ninfas de Leptopharsa heveae (Piracicaba-SP, 1999).

\begin{tabular}{|c|c|c|c|}
\hline Isolado & Patógeno & Procedência & Hospedeiro \\
\hline 1022 & Metarhizium anisopliae & Piracicaba-SP & Phyllophaga sp. \\
\hline 1037 & Metarhizium anisopliae & Porto Alegre-RS & Solenopsis sp. \\
\hline 1076 & Metarhizium anisopliae & Arapongas-PR & Solo \\
\hline 1104 & Metarhizium anisopliae & São João do Piauí-PI & Solo \\
\hline 1144 & Metarhizium anisopliae & Piracicaba-SP & Calosoma granulatum \\
\hline 1175 & Metarhizium anisopliae & Córrego Rico-SP & Solo \\
\hline 1184 & Metarhizium anisopliae & Corumbá-MS & Solo \\
\hline 1189 & Metarhizium anisopliae & Corumbá-MS & Solo \\
\hline 1203 & Metarhizium anisopliae & Pernambuco & Blattodea \\
\hline 1220 & Metarhizium anisopliae & Desconhecido & Cigarrinha do citros \\
\hline 1215 & Nomuraea rileyi & Pelotas-RS & Spodoptera sp. \\
\hline 1243 & Nomuraea rileyi & Piracicaba-SP & Anticarsia gemmatalis \\
\hline 1200 & Paecilomyces fumosoroseus & Amélio Rodrigues-BA & Mahanarva posticata \\
\hline 1205 & Paecilomyces farinosus & Santa Fé do Sul-SP & Bemisia tabaci \\
\hline 1232 & Paecilomyces sp. & Piracicaba-SP & Lagria villosa \\
\hline 581 & Paecilomyces lilacinus & Cuiabá-MT & Solenopsis invicta \\
\hline 592 & Paecilomyces lilacinus & Lavras-MG & Solenopsis sp. \\
\hline 831 & Paecilomyces lilacinus & Piracicaba-SP & Solo \\
\hline 1125 & Paecilomyces lilacinus & C. do Itapemirim-ES & Solo \\
\hline 1224 & Sporothrix insectorum & Brasília-DF & Leptopharsa heveae \\
\hline 1225 & Sporothrix insectorum & S.J.do Rio Claro-MT & Leptopharsa heveae \\
\hline 1226 & Sporothrix insectorum & Itiquira-MT & Leptopharsa heveae \\
\hline 1227 & Sporothrix insectorum & Itiquira-MT & Leptopharsa heveae \\
\hline 1228 & Sporothrix insectorum & Manaus-AM & Leptopharsa heveae \\
\hline 1229 & Sporothrix insectorum & Itiquira-MT & Leptopharsa heveae \\
\hline
\end{tabular}


Tabela 1. Isolados de fungos entomopatogênicos utilizados nos bioensaios com ninfas de Leptopharsa heveae (Piracicaba-SP, 1999).

\begin{tabular}{llll}
\hline Isolado & \multicolumn{1}{c}{ Patógeno } & \multicolumn{1}{c}{ Procedência } & \multicolumn{1}{c}{ Hospedeiro } \\
\hline 1230 & Sporothrix insectorum & Itiquira-MT & Leptopharsa heveae \\
1231 & Trichoderma sp. & Piracicaba-SP & Solo \\
870 & Verticillium lecanii & Piracicaba-SP & Coccus viridis \\
941 & Verticillium sp. & Piracicaba-SP & Cochonilha \\
950 & Verticillium lecanii & Indonésia & Coccus viridis \\
972 & Verticillium sp. & Piracicaba-SP & Cochonilha verde \\
\hline
\end{tabular}

A produção de conídios dos patógenos, foi efetuada em placas de Petri com meio de cultura BDA (200g de batata, 20g dextrose, $15 \mathrm{~g}$ ágar e $1000 \mathrm{~mL}$ de água), em câmara climatizada a $26 \pm 0,5^{\circ} \mathrm{C}$ e fotofase de 12 horas. Após dez dias de incubação os conídios foram colhidos com uma espátula de borracha para a preparação do inóculo.

Os insetos foram inoculados e mantidos em placas de plástico transparente de 6 x 1,5 cm (Corning), contendo em cada placa um disco de folha de seringueira de $5 \mathrm{~cm}$ de diâmetro sobre $10 \mathrm{~mL}$ de ágar-água a $2 \%$ e a borda da folha recoberta. Desta forma, o ágar proporcionou condições adequadas para a conservação dos discos foliares, fornecendo um substrato alimentar adequado aos insetos pelo período de cinco dias, evitando-se a morte dos mesmos por afogamento (Figura 6).

O número de insetos utilizados por repetição foi de dez/placa, perfazendo um total de 50 insetos por tratamento. A seleção de isolados foi realizada sobre ninfas do $4^{\circ}$ ínstar, devido à maior sensibilidade das ninfas mais jovens ao manuseio com pincel. A utilização de adultos nos bioensaios não foi possível por serem alados e de razoável movimentação. No trabalho de Ordonez-Giraldo (1993), o autor mostrou que a contaminação de $L$. gibbicarina pelo fungo $S$. insectorum ocorreu tanto nos estágios de ninfa como de adulto, sendo portanto possível a seleção de isolados nesse estágio. A utilização de ninfas do $5^{\circ}$ ínstar foi realizada por Sanchez e Bellotti (1997), para testar a eficiência de diferentes fungos em Cyrtomenus bergi (Cydnidae). 


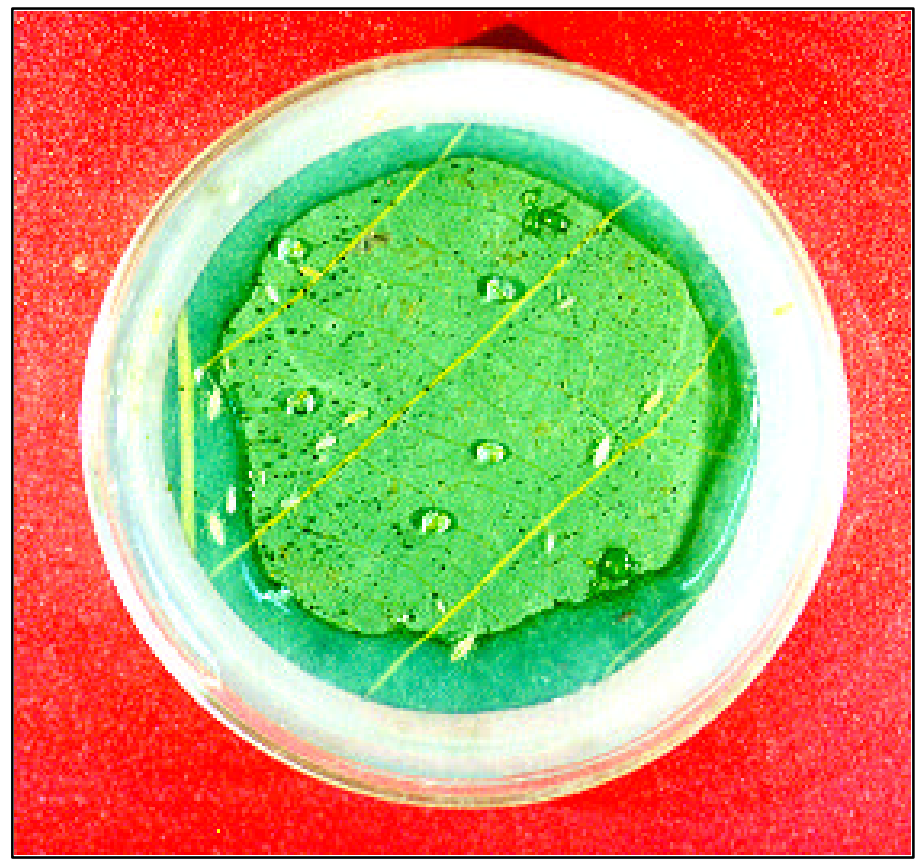

Figura 6- Placa de plástico (6 x 1,5 cm) com ágar-água (2\%) e folha de seringueira (5 $\mathrm{cm} \varnothing$ ) utilizada para a realização de bioensaios com Leptopharsa heveae (Piracicaba-SP, 1999).

Os insetos foram coletados no seringal da ESALQ/USP, onde existe um ensaio de avaliação de produção de clones. Foi constatado que esses não apresentavam contaminação por patógenos, especialmente fungos entomopatogênicos. Todas as coletas foram feitas no dia da realização do bioensaio. Os insetos foram colocados nas placas de plástico com auxílio de um pincel número 0, visando minimizar os danos mecânicos.

A pulverização das ninfas foi realizada utilizando suspensão de conídios na concentração de $1 \times 10^{8}$ conídios/mL, empregando-se a Torre de Potter (Burkand Manufecturing Co Ltd.) e aplicando-se $2 \mathrm{~mL}$ da suspensão, com pressão de 15 libras $/ \mathrm{pol}^{2}$, correspondendo a aproximadamente $2 \times 10^{2}$ conídios $/ \mathrm{mm}^{2} /$ superfície foliar. Após a inoculação, os recipientes com os insetos foram mantidos em câmara climatizada a $26 \pm 0,5^{\circ} \mathrm{C}$ e fotofase de 12 horas durante todo o período experimental. 
Foram realizadas avaliações diárias, por um período de quatro dias após a inoculação. Para confirmação da mortalidade pelo patógeno, os insetos mortos foram diariamente, lavados em álcool $70 \%$ por 10 segundos e enxaguados em água destilada por 20 segundos, para descontaminação externa. Em seguida, foram transferidos para placas plásticas de cultura de tecido. Essas placas permaneceram acondicionadas num recipiente fechado, revestido com uma espuma umedecida diariamente e nas mesmas condições já referidas para os outros bioensaios.

A seleção de isolados foi baseada na porcentagem de mortalidade de L. heveae no período de avaliação, determinando-se assim a patogenicidade de cada fungo para o inseto. Os isolados selecionados foram os que causaram mortalidade igual ou acima de 95\%, três dias após a inoculação, corrigida através da fórmula de Abbott.

\subsection{Resultados e Discussão}

Poucos isolados causaram mortalidade ao $1^{\mathrm{o}}$ dia após a inoculação (d.a.i.), o que é normal devido ao tempo necessário para se completar o ciclo patógenohospedeiro. No $2^{o}$ e $3^{\circ}$ d.a.i., as mortalidades foram crescentes, sendo que ao $4^{\circ}$ d.a.i. apresentaram variação de 13 a 100\% entre os diferentes fungos, tendo também uma grande amplitude entre isolados da mesma espécie (Tabela 2).

A mortalidade confirmada, que representa o número de insetos nos quais se observou a emergência e reprodução do patógeno, variou de 4 a 100\%, com 4 d.a.i. para os isolados testados. Essa diferença entre as porcentagens de mortalidades é pode ser devida, muitas vezes, pela septicemia causada por bactérias, interferindo no crescimento vegetativo do fungo dentro do inseto. Por isso, esse critério não foi utilizado nesta fase de seleção, sendo um parâmetro a mais para se conhecer a causa da morte do inseto nos bioensaios (Tabela 2).

Dentre os fungos testados o que causou menor mortalidade foi o isolado 935 de M. anisopliae matando apenas $13 \%$ das ninfas, sendo que pelo menos um isolado dos 
Tabela 2. Mortalidade corrigida e confirmada de ninfas do $4^{\circ}$ ínstar de Leptopharsa heveae, inoculadas com fungos entomopatogênicos na concentração de $1 \times 10^{8}$ conídios/mL (Piracicaba-SP, 1999).

\begin{tabular}{|c|c|c|c|c|c|c|c|c|}
\hline \multirow[b]{2}{*}{ Número do isolado/Espécie } & \multicolumn{2}{|c|}{1 d.a.i. } & \multicolumn{2}{|c|}{2 d.a.i. } & \multicolumn{2}{|c|}{3 d.a.i. } & \multicolumn{2}{|c|}{4 d.a.i. } \\
\hline & $\%$ mort.corr. & \%mort.conf. & $\%$ mort.corr. & $\%$ mort.conf. & $\%$ mort.corr. & \%mort.conf. & $\%$ mort.corr. & \%mort.conf. \\
\hline 1216A.aleyrodis & 0 & 0 & 6 & 4 & 28 & 8 & 50 & 24 \\
\hline 307 B.bassiana & 0 & 0 & 14 & 14 & 65 & 64 & 85 & 84 \\
\hline 447 B.bassiana & 0 & 0 & 4 & 0 & 73 & 66 & 100 & 92 \\
\hline 457 B.bassiana & 0 & 0 & 6 & 6 & 27 & 27 & 49 & 49 \\
\hline 489 B.bassiana & 0 & 0 & 20 & 20 & 69 & 64 & 87 & 82 \\
\hline 494 B.bassiana & 0 & 0 & 6 & 6 & 58 & 56 & 79 & 76 \\
\hline 868 B.bassiana & 0 & 0 & 8 & 8 & 52 & 48 & 83 & 78 \\
\hline 908 B.bassiana & 0 & 0 & 8 & 8 & 65 & 58 & 91 & 78 \\
\hline 969 B.bassiana & 0 & 0 & 10 & 10 & 60 & 54 & 81 & 74 \\
\hline $1196 B$. bassiana & 0 & 0 & 20 & 20 & 84 & 80 & 100 & 94 \\
\hline 1219B. bassiana & 0 & 0 & 8 & 8 & 36 & 36 & 78 & 78 \\
\hline 1233 B.bassiana & 0 & 0 & 2 & 2 & 31 & 31 & 73 & 38 \\
\hline PL 63 B.bassiana & 0 & 0 & 4 & 4 & 56 & 56 & 96 & 96 \\
\hline 619 B. brogniarti & 0 & 0 & 14 & 10 & 56 & 50 & 100 & 94 \\
\hline 1234 H.verticilioides & 0 & 0 & 2 & 2 & 2 & 2 & 48 & 36 \\
\hline 1235 H.verticilioides & 0 & 0 & 2 & 2 & 13 & 13 & 84 & 60 \\
\hline 1236 H.verticilioides & 2 & 2 & 2 & 0 & 8 & 8 & 70 & 30 \\
\hline 1237 H.verticilioides & 0 & 0 & 4 & 4 & 15 & 14 & 64 & 46 \\
\hline 1221 H.thompsonii & 0 & 0 & 0 & 0 & 4 & 0 & 16 & 12 \\
\hline 798 M. anisopliae & 0 & 0 & 21 & 18 & 34 & 30 & 76 & 70 \\
\hline 860 M.anisopliae & 0 & 0 & 16 & 16 & 57 & 57 & 100 & 78 \\
\hline 865 M.anisopliae & 0 & 0 & 31 & 31 & 51 & 51 & 82 & 82 \\
\hline 866 M. anisopliae & 0 & 0 & 0 & 0 & 64 & 60 & 96 & 86 \\
\hline 867 M.anisopliae & 0 & 0 & 55 & 44 & 85 & 70 & 100 & 76 \\
\hline 935 M. anisopliae & 0 & 0 & 0 & 0 & 4 & 2 & 13 & 4 \\
\hline $1022 M$. anisopliae & 6 & 6 & 58 & 54 & 86 & 80 & 96 & 90 \\
\hline 1037 M.anisopliae & 2 & 2 & 41 & 34 & 70 & 62 & 89 & 68 \\
\hline 1076 M.anisopliae & 0 & 0 & 20 & 18 & 52 & 52 & 86 & 86 \\
\hline 1104M.anisopliae & 0 & 0 & 48 & 46 & 90 & 88 & 100 & 98 \\
\hline 1144M. anisopliae & 14 & 12 & 80 & 68 & 90 & 78 & 98 & 86 \\
\hline 1175 M.anisopliae & 0 & 0 & 44 & 40 & 54 & 50 & 95 & 84 \\
\hline 1184M.anisopliae & 0 & 0 & 30 & 22 & 58 & 48 & 100 & 88 \\
\hline 1189 M. anisopliae & 28 & 28 & 74 & 74 & 88 & 88 & 100 & 100 \\
\hline 1203 M. anisopliae & 8 & 8 & 68 & 68 & 88 & 86 & 96 & 94 \\
\hline 1220 M. anisopliae & 0 & 0 & 29 & 24 & 87 & 72 & 98 & 82 \\
\hline E6 $M$. anisopliae & 14 & 10 & 74 & 68 & 92 & 84 & 100 & 90 \\
\hline E9 M.anisopliae & 2 & 2 & 14 & 14 & 64 & 64 & 98 & 80 \\
\hline RJC M. anisopliae & 8 & 8 & 70 & 70 & 82 & 82 & 98 & 98 \\
\hline RJD M. anisopliae & 8 & 4 & 52 & 48 & 82 & 78 & 96 & 92 \\
\hline $1215 N$. rileyi & 0 & 0 & 4 & 2 & 20 & 12 & 34 & 18 \\
\hline $1243 N$. rileyi & 0 & 0 & 4 & 4 & 20 & 12 & 50 & 44 \\
\hline $1200 P$. fumosoroseus & 0 & 0 & 56 & 56 & 100 & 100 & 100 & 100 \\
\hline 1205P.fumosoroseus & 0 & 0 & 29 & 26 & 81 & 78 & 96 & 92 \\
\hline 1232 P. fumosoroseus & 0 & 0 & 4 & 4 & 19 & 19 & 30 & 30 \\
\hline $581 P$. lilacinus & 0 & 0 & 12 & 10 & 20 & 18 & 34 & 28 \\
\hline 592 P. lilacinus & 2 & 2 & 8 & 8 & 12 & 12 & 26 & 26 \\
\hline $831 P$. lilacinus & 4 & 4 & 10 & 10 & 16 & 16 & 52 & 38 \\
\hline $1125 P$. lilacinus & 0 & 0 & 2 & 0 & 12 & 10 & 36 & 34 \\
\hline 1224 Sinsectorum & 0 & 0 & 4 & 4 & 86 & 68 & 100 & 80 \\
\hline 1225 S.insectorum & 0 & 0 & 2 & 2 & 8 & 8 & 25 & 25 \\
\hline 1226 S.insectorum & 2 & 2 & 10 & 10 & 26 & 26 & 43 & 36 \\
\hline 1227 S.insectorum & 8 & 8 & 20 & 20 & 26 & 26 & 56 & 50 \\
\hline 1228 S.insectorum & 0 & 0 & 10 & 10 & 43 & 36 & 75 & 68 \\
\hline 1229 Sinsectorum & 0 & 0 & 2 & 2 & 92 & 74 & 100 & 82 \\
\hline 1230 Sinsectorum & 0 & 0 & 0 & 0 & 78 & 78 & 96 & 96 \\
\hline 1231 Tricoderma sp. & 0 & 0 & 4 & 4 & 55 & 46 & 78 & 60 \\
\hline 870 V. lecanii & 0 & 0 & 4 & 4 & 14 & 8 & 24 & 18 \\
\hline 941 V. lecanii & 8 & 8 & 16 & 8 & 20 & 8 & 40 & 16 \\
\hline 950 V. lecanii & 0 & 0 & 4 & 2 & 10 & 4 & 26 & 14 \\
\hline 972 V. lecanii & 0 & 0 & 4 & 4 & 48 & 48 & 100 & 98 \\
\hline
\end{tabular}


gêneros Beauveria, Metarhizium, Paecilomyces, Sporothrix e Verticillium, atingiram $100 \%$ de mortalidade (Figuras 7 e 8 ).

O fungo Aschersonia, é conhecido por ocorrer naturalmente sobre espécies de cochonilhas e mosca branca em citros, em diversas localidades do mundo (Alves, 1986; Gravena et al., 1992; Watanabe et al., 1994). Para o percevejo-de-renda-da-seringueira, esse fungo causou 50\% de mortalidade com 4 d.a.i., não mostrando, portanto, ser muito promissor para o controle desse inseto. Esse patógeno está restrito a poucas famílias de insetos e a Tingidae ainda não foi incluída como suscetível.

No Brasil, o fungo B. bassiana ocorre em mais de 30 espécies de insetos. Já foi estudado para o controle de Diatraea saccharalis (Alves, 1986); hemípteros como no percevejo-do-colmo-do-arroz, Tibraca limbativentris (Martins \& Lima, 1994); para Triatoma infestans vetor da doença-de-Chagas (Luz et al., 1998); Nezara viridula, Piezodorus guildinii e Euschistus heros, e para pragas da soja (Sosa-Gomez e Moscardi, 1998). Em outros países foi estudado visando ao controle do coreídeo Riptortus linearis, praga da soja (Hu et al., 1996) e Leptoglossus zonatus (Coreidae) e Pachycoris klugii (Scutelleridae) pragas da nogueira (Grimm \& Guharay, 1998).

Os isolados de Beauveria testados para o percevejo-de-renda-da-seringueira causaram mortalidades de até $20 \%$ com 2 d.a.i. A partir do 3 d.a.i., alguns isolados atingiram mais de $60 \%$ de mortalidade, fato observado também por Neves (1998) na seleção de isolados para C. cumulans e Lopes (1999) para o tripes F. occidentalis, o que torna uma característica interessante desse fungo. Com exceção do isolado 457, todos os outros apresentaram mortalidades corrigidas acima de $73 \%$ no 4 d.a.i., sendo que os isolados 447 e 1196, apresentaram as melhores performances, atingindo $100 \%$ de mortalidade após 4 d.a.i., mostrando serem bastante promissores para o controle desse inseto. O isolado 619, de Beauveria brongniartii, também atingiu $100 \%$ de mortalidade ao 4 d.a.i., mostrando ser também eficiente no controle de ninfas L. heveae.

O fungo Beauveria já mostrou ser eficiente também para diversas pragas do algodão, sendo a formulação Naturalis-L já testada nos Estados Unidos, México, Nicarágua, Paraguai, Egito, Turquia e Austrália (Wright \& Knauf, 1994; Knaulf \& Wright, 1994). No Brasil esse patógeno vem sendo usado na formulação Boveril para 


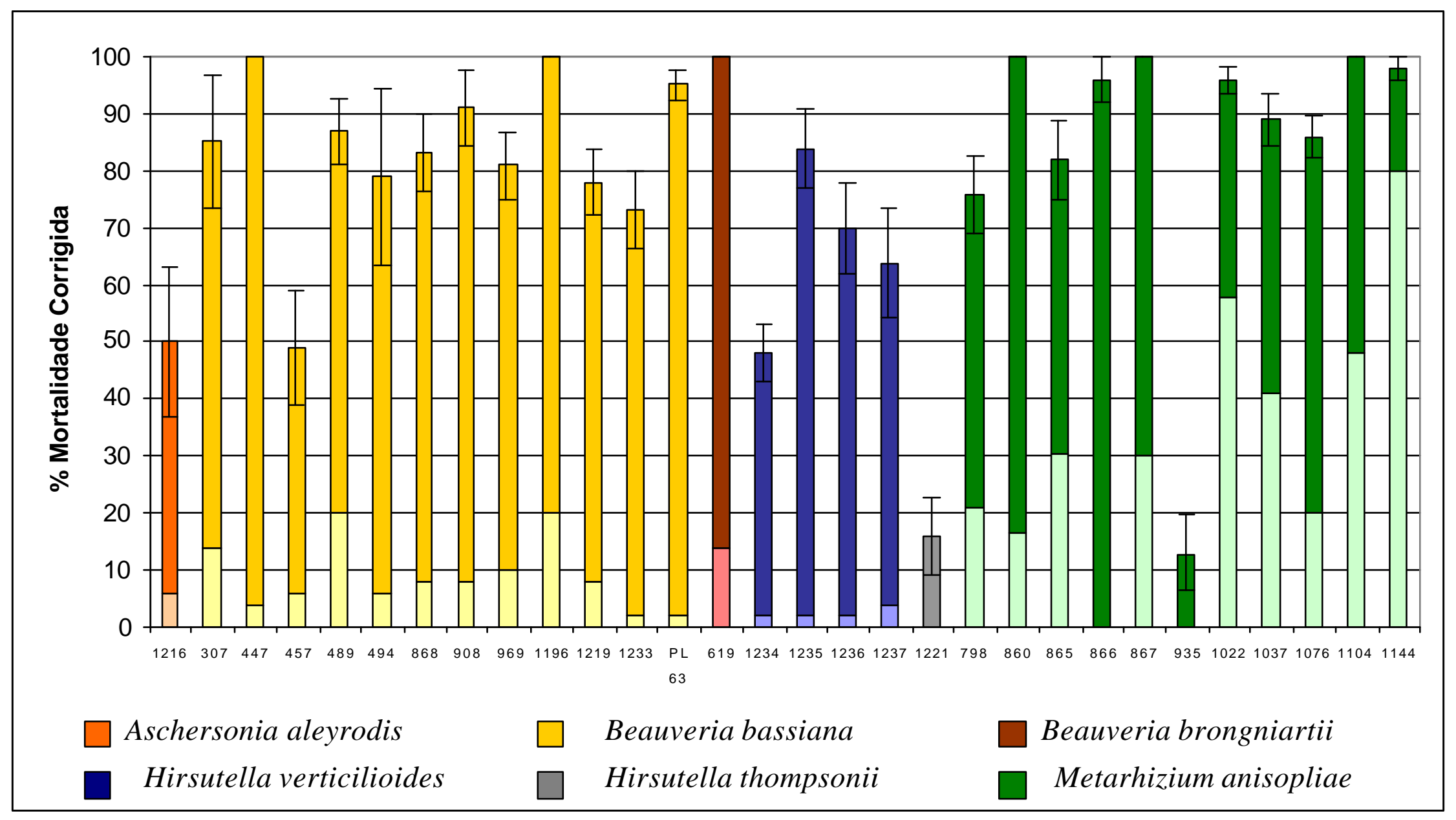

Figura 7- Porcentagens de mortalidade corrigida de ninfas de Leptopharsa heveae, 2 dias (cor clara) e 4 dias (cor escura) após a inoculação com os isolados de fungos entomopatogênicos (Piracicaba-SP, 1999). 


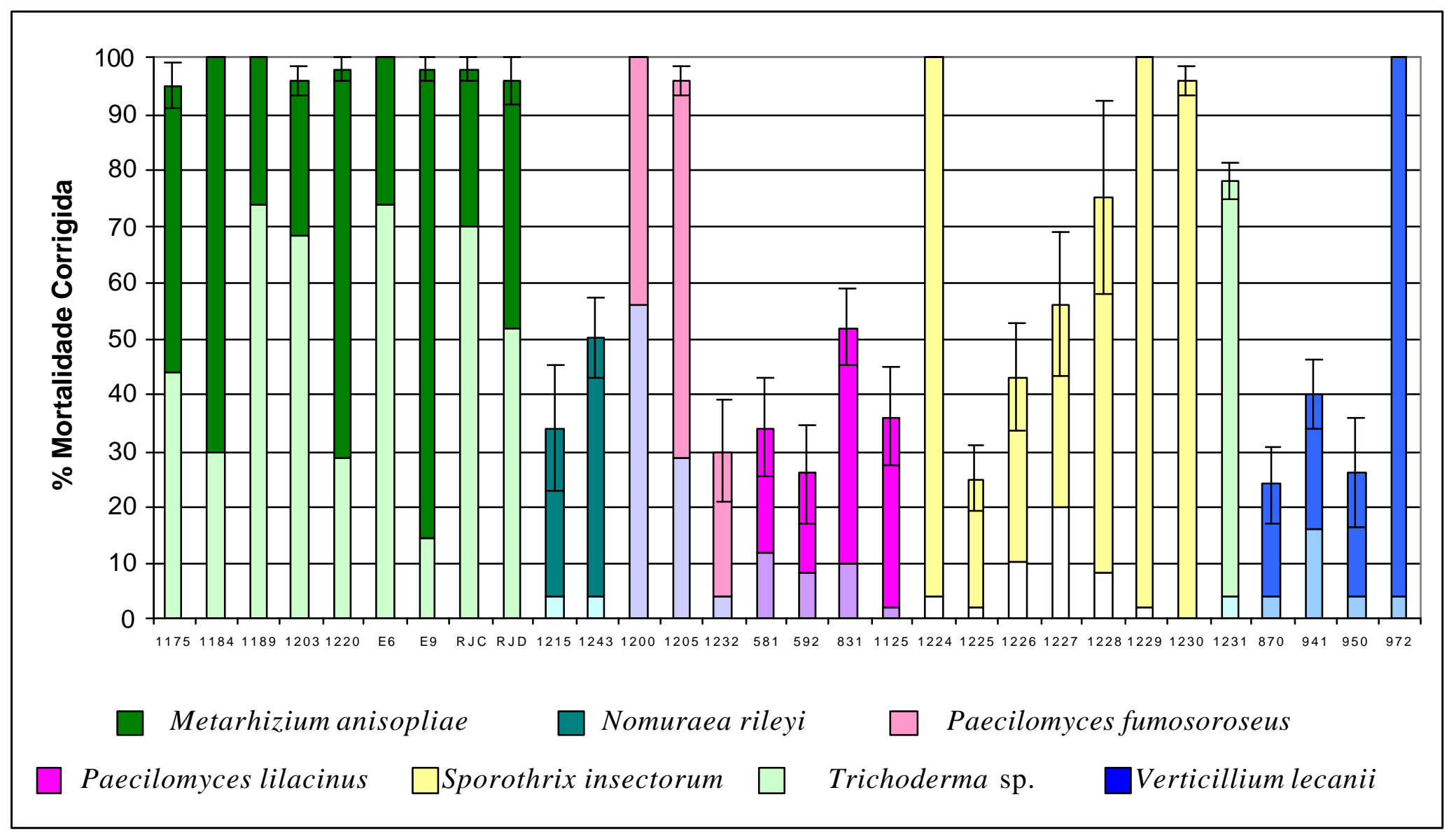

Figura 8- Porcentagens de mortalidade corrigida de ninfas de Leptopharsa heveae, 2 dias (cor clara) e 4 dias (cor escura) após a inoculação com os isolados de fungos entomopatogênicos (Piracicaba-SP, 1999). 
controle de Tetranychus urticae na cultura mamoeiro, broca-do-café e plantas ornamentais (Itaforte Bioprodutos).

O gênero Hirsutella foi estudado principalmente em ácaros por McCoy et al., 1996 e Odongo et al. (1998), mas sua ocorrência já foi relatada também em insetos como $L$. heveae, num levantamento de fungos da região do cerrado (Shimaxu et al., 1994) e em broca da cana-de-açúcar (Chilo sacchariphagus indicus), com infecção natural de $11 \%$ (Easwaramoorthy et al., 1997). Esse patógeno ocorre, naturalmente, nas populações de Calacarus heveae considerado um dos principais problemas da heveicultura e distribuído em todas as regiões produtoras de látex (Tanzini et al., 1999, 2000).

Dos cinco isolados testados, $H$. verticilioides (1235) foi o que apresentou melhor performance com $84 \%$ de eficiência. O isolado 1221 de H. thompsonii causou apenas $16 \%$ de mortalidade, 4 d.a.i. não sendo promissor para a elaboração de um inseticida microbiano. No entanto é importante conhecer a ação desse fungo sobre o percevejo-de-renda-daseringueira, pois tanto o ácaro como esse inseto, têm suas infestações reduzidas após os períodos de chuvas que ocorrem de dezembro a janeiro.

O fungo Metarhizium anisopliae ocorre em diversas regiões do mundo e com uma vasta amplitude de hospedeiros. No Brasil vem sendo usado com sucesso para controle das cigarrinhas das pastagens e de cana-de-açúcar. Sua eficiência de controle para ninfas de percevejo-de-renda-da-seringueira variou de 13 a 100\%, resultados semelhantes foram obtidos com o mesmo fungo para o controle de pragas de grãos armazenados (Moino Jr. et al., 1998), cupins (Almeida et al., 1997 e Neves, 1998) e tripes (Lopes, 1999). Dos vinte isolados testados, ao quarto dia após a inoculação, quinze proporcionaram mortalidade superior a $90 \%$, sendo portanto um fungo muito promissor para o controle de L. heveae.

$\mathrm{O}$ isolado 1144 foi o mais virulento para o percevejo-de-renda-da-seringueira, atingindo $80 \%$ de mortalidade corrigida após 48 horas da inoculação. O efeito rápido de um fungo, é uma característica importante e desejável na estratégia de manejo de uma praga. Esses resultados foram semelhantes aos obtidos por Lopes (1999) com F. occidentalis, atingindo 93\% de eficiência decorrido 24 horas da aplicação. Luz et al. (1998), também selecionaram dois isolados de $M$. anisopliae de um total de treze isolados, com alta virulência para $T$. infestans, o que confirma a possibilidade de utilização desse fungo num programa de controle microbiano. 
O fungo Nomuraea rileyi que normalmente ocorre sobre larvas de lepidópteros (Alves, 1998b), apresentou uma mortalidade mediana para ninfas de L. heveae, chegando a $50 \%$ com 4 d.a.i. Essa eficiência foi semelhante à obtida por Ambethgar \& Loganathan (1998), os quais relataram que em condições naturais em campo de soja com irrigação, o patógeno causou 59\% de mortalidade em Spodoptera litura, após oito dias de aplicação.

O gênero Paecilomyces reúne diversas espécies entomopatogênicas, sendo conhecido por causar o chamado "muscardine amarelo" em insetos e por atacar nematóides de plantas (Alves, 1998). Para o percevejo-de-renda-da-seringueira foram testados $P$. fumusoroseus e $P$. lilacinus, sendo a primeira espécie muito promissora com os isolados 1200 e 1205, causando mais de $80 \%$ de mortalidade com 3 d.a.i. e os demais abaixo de $50 \%$ aos 4 d.a.i. Resultados semelhantes foram observados por Wraight et al., 1998, quando testaram essas duas espécies de fungos para o controle de Bemisia argentifolii, sendo os isolados de $P$. fumosoroseus mais virulentos. Em casa de vegetação, $P$. fumosoroseus causou 70\% de mortalidade em B. argentifolii (Vidal et al., 1998b).

Os isolados 1224, 1229 e 1230 de Sporothrix, causaram mortalidades do percevejo acima de $90 \%$. Os índices de mortalidades causados pelos outros quatro isolados variaram de 25 a 75\%, o que evidencia a grande diversidade genética desses entomopatógenos. Atualmente esse fungo já vem sendo utilizado como uma tática de manejo integrado do percevejo-de-renda-da-seringueira. Celestino Filho \& Magalhães (1986), mostraram que o controle de ninfas de percevejos atingiu a $93 \%$ e de adultos $76 \%$ em condições de campo. A eficiência desse fungo está diretamente ligada as condições ambientais, podendo variar de 25 a 93\%, do período mais seco ao mais úmido, respectivamente (Junqueira et al.,1988).

O gênero Trichoderma é um fungo natural de solo, podendo viver saprofiticamente ou parasitando muitos fungos fitopatogênicos. Sua ação é exercida por meio dos mecanismos de parasitismo, antibiose e competição. Muitas espécies possuem a capacidade de produzir metabólitos tóxicos e enzimas líticas (Melo, 1998). Sua eficiência sobre ninfas de L. heveae atingiu 78\%. Essa boa eficiência pode ter sido devido a ação de antibióticos, os mesmos que têm efeitos sobre os fungos e bactérias (Figura 9). Seria muito interessante a continuidade desse estudo visando aproveitar a possível dupla ação deste entomofitopatógeno no controle microbiano conjunto do percevejo-de-renda-da-seringueira e do fungo Microcyclus ulei, limitante para a cultura da seringueira. 


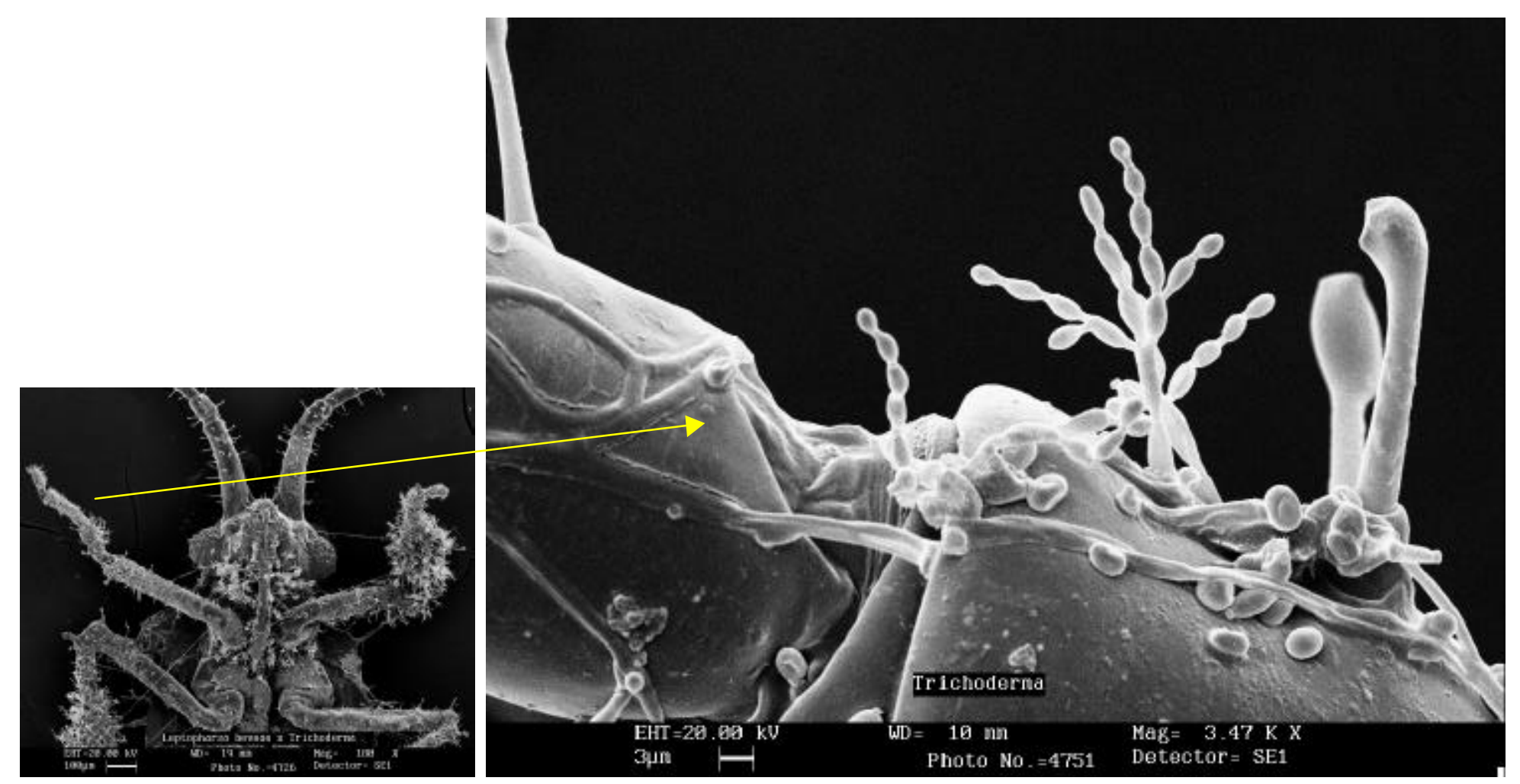

Figura 9- Ninfa de Leptopharsa heveae colonizada pelo fungo Trichoderma sp. No detalhe esporos aderidos e formação de conidióforos sobre o inseto (Piracicaba-SP, 1999). 
O fungo $V$. lecanii é um patógeno que ocorre, freqüentemente, sobre pulgões e cochonilhas nas regiões tropicais e subtropicais (Alves, 1998b). Foi também relatado como hiperparasita de fungos causadores de ferrugens (Melo, 1998). A sua eficiência sobre $L$. heveae, variou de 22 a $100 \%$. O que dificulta a utilização desse patógeno em programas de controle microbiano da praga é o crescimento muito lento em meio sólido, e apresenta baixa produção de conídios em meios semi-sólidos e líquidos.

\subsection{Conclusões}

- Os melhores isolados de fungos entomopatogênicos para controle de Leptopharsa heveae são Metarhizium anisopliae (1144 e E6), Paecilomyces fumosoroseus (1200), Sporothrix insectorum (1229), Beauveria bassiana (1196) e Verticillium lecanii (972).

- O fungo Trichoderma sp., um parasita de muitos fungos fitopatogênicos, causa mortalidade de $78 \%$ em L. heveae. 


\section{UTILIZAÇÃO DE FUNGOS ENTOMOPATOGÊNICOS VISANDO AO CONTROLE DE Leptopharsa heveae EM SERINGUEIRA}

\section{RESUMO}

Foram realizados ensaios para controle de $L$. heveae em condições de campo em Caçú-GO utilizando-se Beauveria spp. (619 e 1196), M. anisopliae (1144 e 1189), P. fumosoroseus (1200), S. insectorum (1229) e V. lecanii (972), e dois experimentos em Itiquira-MT, sendo o primeiro com B. bassiana (447), P. fumosoroseus (1200) e $S$. insectorum (1229). No segundo, além desses fungos, foi também utilizado M. anisopliae (E9, 1175 e 1184). As aplicações foram realizadas com Turbo Atomizador com vazão de 300 L/ha e uma concentração aproximadamente de $4 \times 10^{11}$ conídios/ha. Em Caçú, os melhores resultados para ninfas e adultos foram obtidos com M. anisopliae (1144) e $B$. bassiana (1196). No primeiro ensaio de Itiquira, os resultados não diferiram em relação à testemunha, mas a mortalidade obtida foi de $45 \%$ para ninfas e $52 \%$ para adultos com P. fumosoroseus (1200). No segundo ensaio de Itiquira, para o controle de ninfas destacaram-se M. anisopliae (1175 e 1184) e P. fumosoroseus (1200) e para adultos a melhor performance foi de M. anisopliae (1175) e B. bassiana (447). As concentrações entre 4 e $6 \mathrm{Kg} / \mathrm{ha}$ de $M$. anisopliae (1104) e B. bassiana (1196) foram consideradas satisfatórias para o controle da praga. 


\section{USE OF ENTOMOPHATOGENIC FUNGI TO CONTROL Leptopharsa heveae ON RUBBER TREES}

\section{SUMMARY}

Control of L. heveae was field tested, in Caçú-GO, Brazil using Beauveria spp. (619 and 1196), M. anisopliae (1144 and 1189), P. fumosoroseus (1200), S. insectorum (1229) and Verticillium lecanii (972). Tests were also conducted in Itiquira-MT, Brazil using B. bassiana (447), P. fumosoroseus (1200) and S. insectorum (1229) in the first test, and these isolates plus M. anisopliae (E9, 1175 and 1184) in a second test. The fungi were applied with Turbo Atomizador with flow at $300 \mathrm{~L} / \mathrm{ha}$ and a concentration of $4 \times 10^{11}$ conidia/ha. In Caçú, the best results for nymphs and adults were obtained with M. anisopliae (1144) and B. bassiana (1196). In the first test in Itiquira, the results for fungal treatments were not significantly different from the control. The mortality was 45\% for nymphs and 52\% for adults with P. fumosoroseus (1200). In the second Itiquira test, M. anisopliae (1175 and 1184) and P. fumosoroseus (1200) were the best treatments for control nymphs and M. anisopliae (1175) and B. bassiana (447) for control of adults. Concentrations between 4 a $6 \mathrm{Kg} / \mathrm{ha}$ of $M$. anisopliae (1104) and $B$. bassiana (1196) were considered adequate for the control of the lacebug.

\subsection{Introdução}

O sucesso do desenvolvimento e utilização de um entomopatógeno como inseticida microbiano depende de uma série de fatores. Alguns são difíceis de serem controlados em condições de campo, como é o caso da temperatura, umidade, luminosidade, $\mathrm{pH}$ etc. Outros podem ser devidamente manejados, como a escolha de uma estratégia correta, uso de raças adequadas, concentração de inóculo entre outros (Alves, 1998b). 
$\mathrm{Na}$ literatura existem vários trabalhos mostrando a eficiência de fungos em condições de campo como de Wright (1993) que avaliou a eficiência do micoinseticida Naturalis-L, a base de B. bassiana, contra o bicudo Anthonomus grandis grandis, e concluiu que as parcelas tratadas com o fungo foram tão produtivas quanto as pulverizadas com produtos químicos.

Sobre percevejos da soja, Sosa Gomez \& Morcardi (1998) testaram isolados de M. anisopliae e B. bassiana em condições de campo e observaram que $B$. bassiana foi menos eficiente contra os percevejos do que $M$. anisopliae. O tempo médio de mortalidade causada por M. anisopliae foi de 4,3 dias para Piezodorus guildinii; 4,6 dias para Nezara viridula e 7,4 dias para Euchistus heros.

Avaliou-se em cultivares de tomate, couve e pepino, em casa de vegetação a eficiência de Paecilomyces fumosoroseus para controle de mosca-branca, Bemisia argentifolii. Os resultados mostraram que o fungo causou mortalidades acima de $70 \%$ (Vidal et al., 1998).

Em milho, Li Chang \& Hou (1998) testaram Nomuraea rileyi para controle de ninfas do $4^{\circ}$ ínstar de Helicoverpa armigera utilizando uma suspensão de $10^{7}$ conídios/mL e observaram mortalidades acima de 90\% com TL50 de 5,9 a 6,7 dias.

Ainda em condições de campo, vários ensaios usando fungos foram realizados com outras pragas como formigas (Silva \& Diehl Fleig, 1988; Machado et al., 1988), tripes (Ekesi et al., 1998; Lopes, 1999) pulgões (Poprawski et al., 1999), cupins (Almeida et al., 1998; Rath, 2000), gafanhotos (Langewald et al., 1999; Magalhães et al., 2000) entre outros.

$\mathrm{Na}$ cultura da seringueira são escassos os trabalhos de controle microbiano em condições de campo. Junqueira et al. (1987) utilizaram S. insectorum para controle de $L$. heveae e os autores ressaltaram que a concentração da suspensão conidial deve ser superior a $10^{7}$ conídios/mL, e as pulverizações devem ser realizadas no final da tarde de dias não sujeitos a chuvas fortes. Nessas condições, dois meses após a aplicação, os resultados foram superiores a $70 \%$ tanto para ninfas como adultos, atingindo $100 \%$ nos seringais com copas mais densas. 
Essa estratégia de utilização de $S$. insectorum e a aplicação de inseticidas, tem sido realizadas em seringais no Brasil para o controle do percevejo-de-renda-daseringueira e de forma empírica, sem estudos de concentrações adequadas e necessárias para a comprovada ação desse patógeno.

O objetivo desse trabalho foi de avaliar a eficiência de diferentes concentrações de conídios provenientes de fungos selecionados em laboratório, visando ao controle do percevejo-de-renda-da-seringueira em seringais de cultivo.

\subsection{Material e Métodos}

\subsubsection{Avaliação de diferentes concentrações de conídios de fungos em condições de campo}

Como as diferenças de clima, solo, topografia, entre outros, interferem bastante nos resultados de eficiências de fungos entomopatogênicos, procurou-se realizar ensaios em diferentes localidades.

\subsubsection{Ensaio 1- Controle do percevejo-de-renda-seringueira em Itiquira-MT}

Foi realizado na Fazenda da Plantações E. Michelin, Itiquira, distante $310 \mathrm{~km}$ a sudeste de Cuiabá-MT, durante o período de 10 de dezembro de 1999 e 3 de janeiro de 2000. Foi utilizado o clone GT1 com 9 anos de plantio, considerado suscetível para o inseto (Tanzini, 1996). Para a primeira aplicação os fungos foram produzidos no laboratório da própria fazenda. Na segunda aplicação, a produção do patógeno foi realizada no laboratório de Patologia e Controle Microbiano de Insetos da ESALQ/USP. Os tratamentos foram distribuídos conforme as diferentes concentrações (Tabela 3). 
Tabela 3. Isolados de fungos entomopatogênicos e concentrações utilizadas no controle de Leptopharsa heveae (Itiquira-MT, 2000).

\begin{tabular}{lccc}
\hline \multicolumn{1}{c}{ Tratamentos } & Isolado & $\begin{array}{c}\text { (Conídios/ha 1 }^{\mathbf{a}} \\
\text { aplicação) }\end{array}$ & $\begin{array}{c}\text { (Conídios/ha 2a }^{\mathbf{a}} \\
\text { aplicação) }\end{array}$ \\
\hline (M.a. 1) Metarhizium anisopliae & 1104 & $2 \mathrm{Kg}\left(5,8 \times 10^{10}\right)$ & $1 \mathrm{Kg}\left(2,0 \times 10^{12}\right)$ \\
(M.a. 2) Metarhizium anisopliae & 1104 & $4 \mathrm{Kg}\left(1,2 \times 10^{11}\right)$ & $3 \mathrm{Kg}\left(6,0 \times 10^{12}\right)$ \\
(M.a. 3) Metarhizium anisopliae & 1104 & $6 \mathrm{Kg}\left(1,7 \times 10^{11}\right)$ & $6 \mathrm{Kg}\left(1,7 \times 10^{13}\right)$ \\
(B.b.1) Beauveria bassiana & 1196 & $3 \mathrm{Kg}\left(5,7 \times 10^{10}\right)$ & $1 \mathrm{Kg}\left(9,0 \times 10^{12}\right)$ \\
(B.b.2) Beauveria bassiana & 1196 & $6 \mathrm{Kg}\left(1,1 \times 10^{11}\right)$ & $3 \mathrm{Kg}\left(2,7 \times 10^{13}\right)$ \\
(B.b.3) Beauveria bassiana & 1196 & $9 \mathrm{Kg}\left(1,7 \times 10^{11}\right)$ & $5 \mathrm{Kg}\left(4,5 \times 10^{13}\right)$ \\
(S.i. 1) Sporothrix insectorum & 1229 & $2,5 \mathrm{~L}\left(2,5 \times 10^{11}\right)$ & $2,5 \mathrm{~L}\left(2,5 \times 10^{11}\right)$ \\
(S.i. 2) Sporothrix insectorum & 1229 & $6 \mathrm{~L}\left(6,5 \times 10^{11}\right)$ & $6 \mathrm{~L}\left(6,5 \times 10^{11}\right)$ \\
\hline
\end{tabular}

\subsubsection{Ensaio 2- Controle do percevejo-de-renda-seringueira em Caçú-GO}

Foi conduzido na Fazenda Santa Maria, em Caçú, localizada 330km a sudoeste de Goiânia-GO, de 22 de novembro de 1999 a 3 de janeiro de 2000, com clone PB 235 com 11 anos de idade. Para esse ensaio os fungos foram produzidos na ESALQ/USP e enviados para o local no período de aplicação. Os tratamentos foram distribuídos conforme a Tabela 4.

Tabela 4. Isolados de fungos entomopatogênicos e concentrações utilizadas no controle de Leptopharsa heveae (Caçú-GO, 2000).

\begin{tabular}{lccc}
\hline \multicolumn{1}{c}{ Tratamentos } & Isolado & $\begin{array}{c}\text { Kg /ha (1 } \mathbf{1}^{\mathbf{a}} \mathbf{e} \mathbf{2}^{\mathbf{a}} \\
\text { aplicação) }\end{array}$ & $\begin{array}{c}\text { Conídios/ha (1 } \\
\mathbf{2}^{\mathbf{a}} \mathbf{e}\end{array}$ \\
\hline aplicação)
\end{tabular}


Em ambos ensaios, com 21 dias após a primeira aplicação foram reaplicados os tratamentos, isso foi realizado devido a eclosão de ninfas, que segundo Tanzini (1998) pode variar de 12 a 20 dias.

Os fungos utilizados no experimento foram produzidos em bandejas plásticas sobre arroz pré-cozido, segundo metodologia proposta por Alves \& Pereira (1989).

As suspensões de conídios foram preparadas pela lavagem do arroz, sendo posteriormente filtradas e diluídas nas concentrações referidas. Foi utilizado um volume de $300 \mathrm{~L} / \mathrm{ha}$ sendo as aplicações realizadas pela atomização da suspensão de conídios com o Turbo Atomizador, série seringueira da FMCopling (Figura 10).

O delineamento estatístico utilizado, em ambas localidades, foi em faixas. Foram realizadas cinco repetições, constando cada uma de quatro árvores escolhidas ao acaso e avaliando-se cinco folhas de cada, onde foi observado o número de insetos vivos. No primeiro ensaio as avaliações foram realizadas aos 5, 10, 17, 24 e 34 dias após aplicação (d.a.a.) e no segundo, aos 10, 20, 30 e 40 d.a.a., respectivamente.

Os dados foram analisados e submetidos à análise de variância e as médias comparadas pelo teste de Tukey $(\mathrm{P} \leq 0,05)$ e as eficiências de controle obtidas por Henderson \& Tilton (1955).

\section{Avaliação de diferentes fungos no controle de Leptopharsa heveae na cultura da seringueira}

Para a avaliação da eficiência de diferentes fungos entomopatogênicos em condições de campo, foi realizado um ensaio na Fazenda Santa Maria, Caçú, no período de 28/10 a 7/12/2000 no clone PB 235 e dois ensaios na Plantações E. Michelin, Itiquira, de 2/11 a 13/11/2000 e outro de 14/11 a 5/12/2000 no clone GT 1.

Alguns fungos utilizados nos ensaios não foram os selecionados, devido a problemas de contaminação e deficiência do isolado em atingir as concentrações desejadas. Cabe lembrar, que os isolados da Tabela 5, apresentaram mortalidades acima de $90 \%$ ao 4 d.a.a. em condições de laboratório. 




Figura 10- A- Turbo atomizador, série seringueira da FMCopling, utilizado para aplicação dos tratamentos nas áreas dos ensaios em Caçú-GO e ItiquiraMT. B e C- Aplicação de suspensão conidial de fungo com vazão de 300 L/ha em seringal com alta infestação de Leptopharsa heveae. (Itiquira-MT, 2000). 
Tabela 5. Isolados dos fungos utilizados nos experimentos de Caçú-GO e Itiquira-MT, visando ao controle de Leptopharsa heveae.

\begin{tabular}{lccc}
\hline \multirow{2}{*}{ Fungos utilizados } & \multicolumn{3}{c}{ Isolados utilizados nos ensaios } \\
& $\mathbf{1}^{\mathbf{0}}$ Ensaio & $\mathbf{2}^{\mathbf{0}}$ Ensaio & $\mathbf{3}^{\mathbf{0}}$ Ensaio \\
\hline Beauveria spp. & 619 e 1196 & 447 & 447 \\
Metarhizium anisopliae & 1144 e 1189 & - & E9, 1175 e 1184 \\
Paecilomyces fumosoroseus & 1200 & 1200 & 1200 \\
Sporothrix insectorum & 1229 & 1229 & 1229 \\
Verticillium lecanii & 972 & - & - \\
\hline
\end{tabular}

A produção dos fungos, preparo das suspensões, quantidade de calda/ha, delineamento estatístico e número de repetições foram realizados conforme os ensaios anteriores. A concentração foi padronizada em $4 \mathrm{Kg} / \mathrm{ha}$. No primeiro ensaio as avaliações foram realizadas aos 10, 20, 30 e 40 dias após aplicação (d.a.a.), no segundo, aos 5 e 10 d.a.a. e no terceiro aos 6,10 e 20 d.a.a.

\subsection{Resultados e Discussão}

\subsubsection{Avaliação de diferentes concentrações de conídios dos fungos em condições de campo}

\subsubsection{Ensaio 1- Controle do percevejo-de-renda-seringueira em Itiquira-MT}

$\mathrm{Na}$ avaliação do número de ninfas vivas de $L$. heveae, pôde-se observar que $B$. bassiana, (B.b.1) apresentou baixa eficiência de controle na menor concentração, no decorrer do ensaio (Tabela 6), com exceção aos 10 d.a.a. quando a população de ninfas permaneceu em torno de 0,2/folha, não sendo suficiente para manter o nível populacional baixo, pois com 17 d.a.a. houve um aumento para 3 ninfas/folha, devido a 
eclosão desses insetos que ocorre, em média, em 12 dias. As maiores concentrações (B.b.2 e B.b.3) foram consideradas bastante satisfatórias.

A eficiência de $M$. anisopliae, na menor concentração (M.a. 1) foi semelhante a B.b.1 aos 17 d.a.a., aumentando somente aos 34 d.a.a. (Figura 11). A concentração conidial intermediária (M.a.2) apresentou eficiência média de aproximadamente 38\%. Na maior concentração (M.a. 3), com exceção aos 10 d.a.a. em que houve aumento de 2,6 vezes da população, as avaliações mostraram-se satisfatórias.

Já com S. insectorum, na menor concentração (S.i. 1), observou-se o mesmo fato ocorrido com M. anisopliae aos 17 e 24 d.a.a. Na maior concentração (S.i. 2) a eficiência foi de 55\%, um pouco menos que a obtida por Junqueira et al. (1987) que dois meses após aplicação, obteve $70 \%$ de controle de ninfas. Essa diferença foi, provavelmente, devido aos períodos de avaliação serem distintos. Outro fator que os autores citaram, foi a influência da densidade da copa, que na mais densa atingiu 100\% de mortalidade.

Nas avaliações aos 17 e 34 d.a.a. sobre ninfas (Figura 11), pode-se notar altas eficiências de controle para as maiores concentrações de B. bassiana (B.b.1 e B.b.2) e em todas de $M$. anisopliae com 34 d.a.a., sendo que na maior concentração o fungo $M$. anisopliae (M.a. 3) já apresentou bom desempenho aos 17 d.a.a. Essa é uma característica bastante desejável para o fungo num programa de controle microbiano. Altas eficiências do isolado 1104, foram observadas também por Lopes (1999) para controle de Frankliniella occidentallis na cultura de alface hidropônica.

$\mathrm{Na}$ avaliação de adultos vivos de $L$. heveae, as elevadas concentrações de $B$. bassiana (B.b.3) e de M. anisopliae (M.a.3), apresentaram resultados considerados ótimos para a utilização de um patógeno em condições de campo, semelhante a aplicação de um inseticida químico (Tabela 7). Para S. insectorum, somente aos 24 d.a.a. houve diferença entre as duas concentrações, tendo eficiências de 51 e 61\%, respectivamente, para S.i.1 e S.i.2, que foram consideradas muito baixas.

Com 17 e 34 d.a.a. visando ao controle de adultos (Figura 12), pôde-se notar a igualdade na eficiência das concentrações intermediárias e a maior de B. bassiana, e um 
Tabela 6. Número de ninfas vivas/folha de Leptopharsa heveae, após a aplicação das concentrações de fungos entomopatogênicos (Itiquira - MT, 2001).

\begin{tabular}{|c|c|c|c|c|c|c|c|c|c|c|c|}
\hline \multirow[b]{2}{*}{ Tratamentos } & \multirow{2}{*}{$\begin{array}{l}\text { Prévia } \\
10 / 12 / 99\end{array}$} & \multicolumn{2}{|c|}{5 d.a.a. } & \multicolumn{2}{|c|}{10 d.a.a. } & \multicolumn{2}{|c|}{17 d.a.a. } & \multicolumn{2}{|c|}{24 d.a.a. } & \multicolumn{2}{|c|}{34 d.a.a. } \\
\hline & & $15 / 12 / 99$ & $(\% \mathrm{EF})$ & $20 / 12 / 99$ & $(\% \mathrm{EF})$ & $27 / 12299$ & $(\% \mathrm{EF})$ & $03 / 01 / 00$ & $(\% \mathrm{EF})$ & $13 / 01 / 00$ & $(\% \mathrm{EF})$ \\
\hline Testemunha & $1,14 \mathrm{~b}$ & $0,41 \mathrm{ab}$ & - & $0,40 \mathrm{ab}$ & - & $1,26 \mathrm{ab}$ & - & $0,20 \mathrm{abc}$ & - & $0,25 \mathrm{ab}$ & - \\
\hline B.b. 1 & $1,24 \mathrm{~b}$ & $0,67 \mathrm{ab}$ & 0,00 & $0,18 \mathrm{~b}$ & 58,63 & $2,77 \mathrm{a}$ & 0,00 & $0,41 \mathrm{ab}$ & 0,00 & $0,27 \mathrm{a}$ & 0,71 \\
\hline B.b. 2 & $2,21 \mathrm{ab}$ & $0,20 \mathrm{~b}$ & 74,84 & $0,27 \mathrm{~b}$ & 65,18 & $0,72 \mathrm{~b}$ & 70,52 & $0,19 \mathrm{abc}$ & 51,00 & $0,17 \mathrm{abc}$ & 64,92 \\
\hline B.b. 3 & $5,84 \mathrm{a}$ & $0,92 \mathrm{a}$ & 56,20 & $1,23 \mathrm{ab}$ & 39,97 & $1,07 \mathrm{ab}$ & 83,42 & $0,03 \quad \mathrm{c}$ & 97,07 & $0,20 \mathrm{abc}$ & 84,38 \\
\hline M.a. 1 & $2,08 \mathrm{ab}$ & $0,38 \mathrm{ab}$ & 49,20 & $0,23 \mathrm{~b}$ & 68,49 & $2,25 \mathrm{a}$ & 2,13 & $0,53 \mathrm{a}$ & 0,00 & $0,16 \mathrm{abc}$ & 64,92 \\
\hline M.a. 2 & $0,84 \mathrm{~b}$ & $0,13 \mathrm{~b}$ & 56,97 & $0,18 \mathrm{~b}$ & 38,93 & $0,63 \mathrm{~b}$ & 32,14 & $0,13 \mathrm{bc}$ & 11,79 & $0,09 \quad \mathrm{c}$ & 51,14 \\
\hline M.a. 3 & 4,48 a & $0,54 \mathrm{ab}$ & 66,49 & $1,40 \mathrm{a}$ & 10,94 & $1,40 \mathrm{ab}$ & 71,73 & $0,08 \quad b c$ & 89,82 & $0,11 \quad b c$ & 88,80 \\
\hline S.i. 1 & $1,94 \mathrm{ab}$ & $0,35 \mathrm{ab}$ & 49,84 & $0,20 \mathrm{~b}$ & 70,62 & $2,15 \mathrm{ab}$ & 0,00 & $0,53 \mathrm{a}$ & 0,00 & $0,19 \mathrm{abc}$ & 55,34 \\
\hline S.i. 2 & $0,98 \mathrm{~b}$ & $0,16 \mathrm{~b}$ & 54,60 & $0,18 \mathrm{~b}$ & 47,65 & $0,71 \quad b$ & 34,45 & $0,10 \quad b c$ & 41,84 & $0,11 \quad b c$ & 48,82 \\
\hline $\mathrm{F}$ & $5,29 *$ & 3,29 n.s. & & $4,53^{*}$ & & $5,20 *$ & & $5,76^{*}$ & & $4,15^{*}$ & \\
\hline C.V.(\%) & 15,81 & 7,18 & & 10,28 & & 10,98 & & 4,58 & & 42,53 & \\
\hline
\end{tabular}

Tabela 7. Número de adultos vivos/folha de Leptopharsa heveae, após a aplicação das concentrações de fungos entomopatogênicos (Itiquira- MT, 2001).

\begin{tabular}{|c|c|c|c|c|c|c|c|c|c|c|c|}
\hline \multirow[b]{2}{*}{ Tratamentos } & \multirow{2}{*}{$\begin{array}{l}\text { Prévia } \\
10 / 12 / 99\end{array}$} & \multicolumn{2}{|c|}{5 d.a.a. } & \multicolumn{2}{|c|}{10 d.a.a. } & \multicolumn{2}{|c|}{17 d.a.a. } & \multicolumn{2}{|c|}{24 d.a.a. } & \multicolumn{2}{|c|}{34 d.a.a. } \\
\hline & & $15 / 12 / 99$ & $(\% \mathrm{EF})$ & $20 / 12 / 99$ & $(\% \mathrm{EF})$ & $27 / 12 / 99$ & $(\% \mathrm{EF})$ & $03 / 01 / 00$ & $(\% \mathrm{EF})$ & $13 / 01 / 00$ & $(\% \mathrm{EF})$ \\
\hline Testemunha & $0,21 \quad b$ & $1,14 \mathrm{abc}$ & - & $0,70 \mathrm{a}$ & - & $0,23 \mathrm{ab}$ & - & $0,62 \mathrm{bcd}$ & - & $0,03 \quad b$ & - \\
\hline B.b. 1 & $0,74 \mathrm{~b}$ & $0,78 \mathrm{bc}$ & 80,58 & $1,06 \mathrm{a}$ & 57,03 & $0,45 \mathrm{ab}$ & 44,48 & $1,03 \mathrm{a}$ & 52,86 & $0,13 \mathrm{a}$ & 0,00 \\
\hline B.b. 2 & $0,22 \mathrm{~b}$ & $0,92 \mathrm{abc}$ & 22,97 & $0,85 \mathrm{a}$ & 0,00 & $0,09 \quad b$ & 62,65 & 0,53 cde & 18,40 & $0,01 \quad b$ & 68,18 \\
\hline B.b. 3 & $0,84 \mathrm{ab}$ & $0,84 \mathrm{bc}$ & 81,58 & 0,95 a & 66,07 & $0,33 \mathrm{ab}$ & 64,13 & 0,14 & 94,35 & $0,04 \quad b$ & 66,67 \\
\hline M.a. 1 & $0,42 \mathrm{~b}$ & $1,56 \mathrm{a}$ & 31,58 & $1,05 \mathrm{a}$ & 25,00 & $0,62 \mathrm{a}$ & 0,00 & $0,84 \mathrm{ab}$ & 32,26 & $0,07 \mathrm{ab}$ & 0,00 \\
\hline M.a. 2 & $0,12 \mathrm{~b}$ & $1,02 \mathrm{abc}$ & 0,00 & $0,55 \mathrm{a}$ & 0,00 & $0,10 \mathrm{~b}$ & 23,91 & 0,44 & 0,00 & $0,03 \quad b$ & 0,00 \\
\hline M.a. 3 & $1,60 \mathrm{a}$ & $0,65 \mathrm{c}$ & 92,52 & $0,81 \mathrm{a}$ & 84,81 & $0,64 \mathrm{a}$ & 63,48 & 0,18 & 96,19 & $0,03 \quad b$ & 86,88 \\
\hline S.i. 1 & $0,50 \mathrm{~b}$ & $1,39 \mathrm{abc}$ & 48,79 & $0,78 \mathrm{a}$ & 53,20 & $0,26 \mathrm{ab}$ & 52,52 & $0,72 \quad b c$ & 51,23 & $0,08 \mathrm{ab}$ & 0,00 \\
\hline S.i. 2 & $0,28 \mathrm{~b}$ & $0,50 \quad \mathrm{c}$ & 67,11 & $0,56 \mathrm{a}$ & 40,00 & $0,09 \quad b$ & 70,65 & 0,32 & 61,29 & $0,03 \quad b$ & 25,00 \\
\hline $\bar{F}$ & $7,51 *$ & $5,69^{*}$ & & 1,95 n.s. & & $5,72 *$ & & $29,61 *$ & & $3,81 *$ & \\
\hline C.V. $(\%)$ & 7,82 & 32,74 & & 37,21 & & 64,68 & & 22,96 & & 84,98 & \\
\hline
\end{tabular}




$$
\text { Illolin }
$$




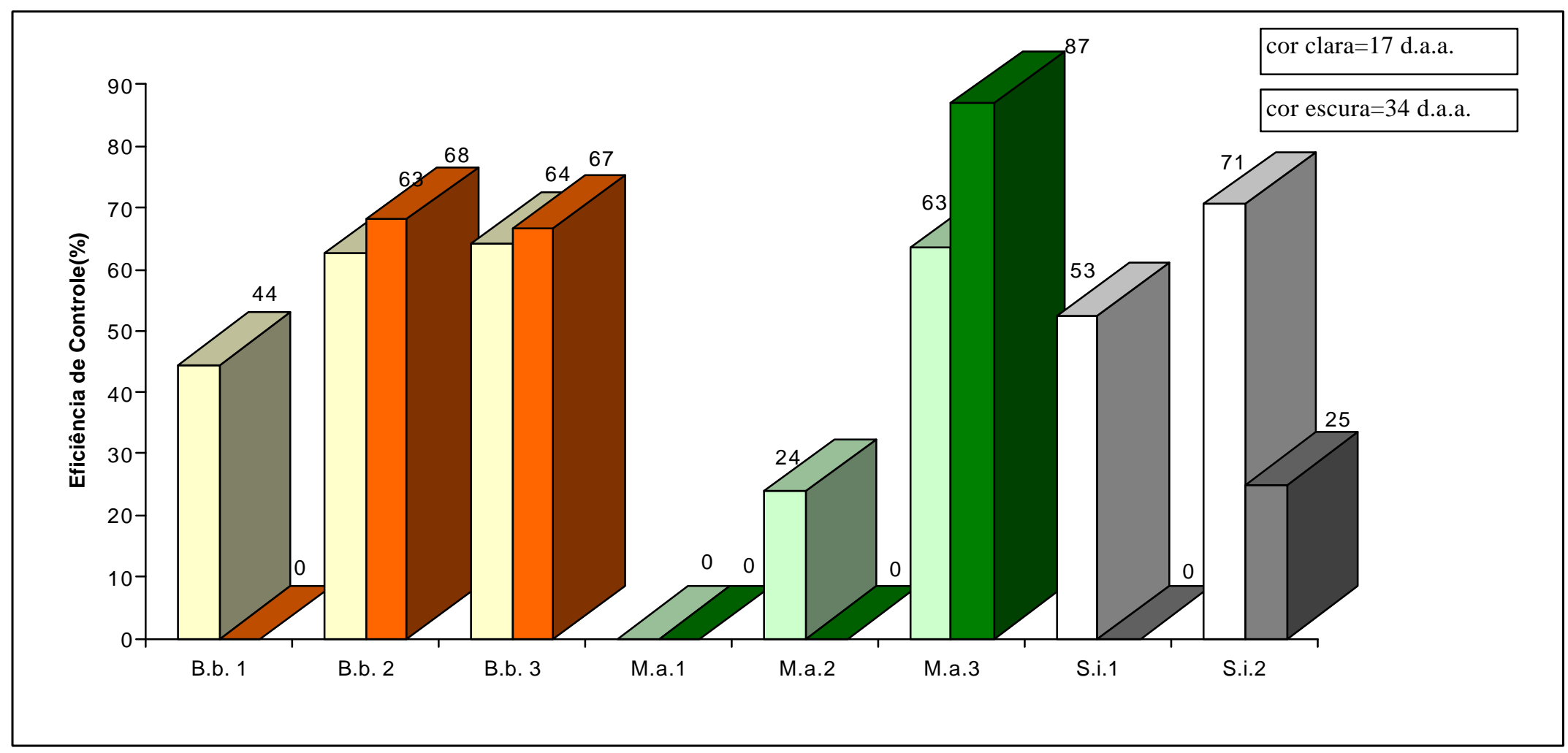

Figura 12- Eficiência de controle de adultos de Leptopharsa heveae aos 17 e 34 dias após aplicação com diferentes concentrações e fungos entomopatogênicos (Itiquira- MT, 2001). 
destaque da maior concentração de M. anisopliae (M.a.3). Já S. insectorum, foi mais eficiente aos 17 d.a.a., tendo eficiência de controle nula e muito baixa, para S.i.1 e S.i.2, respectivamente. Esse fato, provavelmente, foi devido a diminuição geral da população do inseto no último dia de avaliação o que pode ter sido causado pela dispersão do mesmo ou pela disseminação do fungo entre os tratamentos.

Esse tipo de dispersão foi comprovado por Sosa Gomez \& Moscardi (1998) em aplicação de M. anisopliae para o controle dos percevejos da soja. Em condições de campo, logo após a aplicação do fungo determinou-se em folhas da cultura 8,3 unidades formadoras de colônia/ $/ \mathrm{mm}^{2}$ e em áreas não tratadas formaram-se 3,6 u.f.c. $/ \mathrm{mm}^{2}$. Segundo Alves \& Lecuona (1998), as doenças em insetos são causadas pela imigração de insetos doentes ou a partir de estruturas do patógeno, trazidas pelo vento, água, pássaros, insetos predadores e parasitos e outros animais.

\subsubsection{Ensaio 2- Controle do percevejo-de-renda-seringueira em Caçú-GO}

Em Caçú, foram realizados ensaios distintos para os fungos testados. Na avaliação de ninfas de $L$. heveae, os resultados com B. bassiana mostraram diferenças estatísticas a partir de 20 d.a.a. sendo consideradas baixas as eficiências de controle. Aos 40 d.a.a. a maior mortalidade foi observada com a menor concentração do fungo $(2 \mathrm{Kg} / \mathrm{ha})$ atingindo $41 \%$, sendo que a concentração intermediária ( $4 \mathrm{Kg} / \mathrm{ha}$ ) causou $52 \%$. Assim, os resultados desse ensaio foram diferentes dos obtidos em Itiquira, onde as maiores concentrações do patógeno apresentaram altas eficiências no controle do percevejo (Figura 13).

Para o controle de adultos, as eficiências foram satisfatórias a partir de 20 d.a.a.,

chegando aos 40 d.a.a. com mortalidade de $80 \%$ nas concentrações de 2 e $4 \mathrm{Kg} / \mathrm{ha}$ (Figura 14). Esses resultados foram semelhantes aos obtidos em Itiquira.

Utilizando M. anisopliae, foi possível observar altas eficiências a partir de 20 d.a.a. nas maiores concentrações (4 a $6 \mathrm{Kg} / \mathrm{ha}$ ) para ninfas e adultos, mantendo-se o controle até aos 40 d.a.a. Também foi observado um efeito cumulativo das aplicações na menor concentração $(2 \mathrm{Kg} / \mathrm{ha}$ ) (Figuras 15 e 16). As eficiências de controle de ninfas foram consideradas ótimas para um patógeno aplicado em condições de campo. 


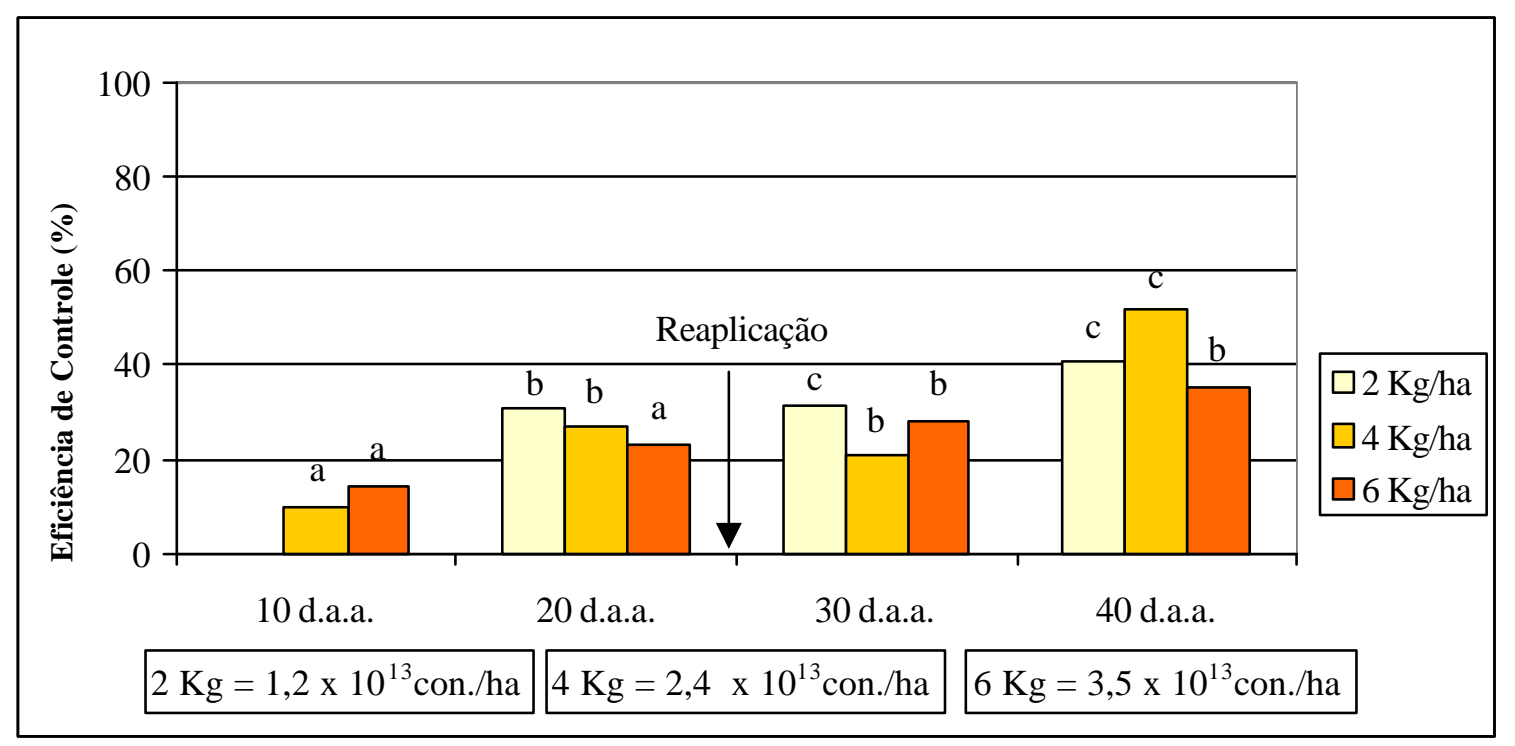

Figura 13- Eficiência de Beauveria bassiana, isolado 1196, no controle de ninfas de Leptopharsa heveae (Caçú-GO, 2001).

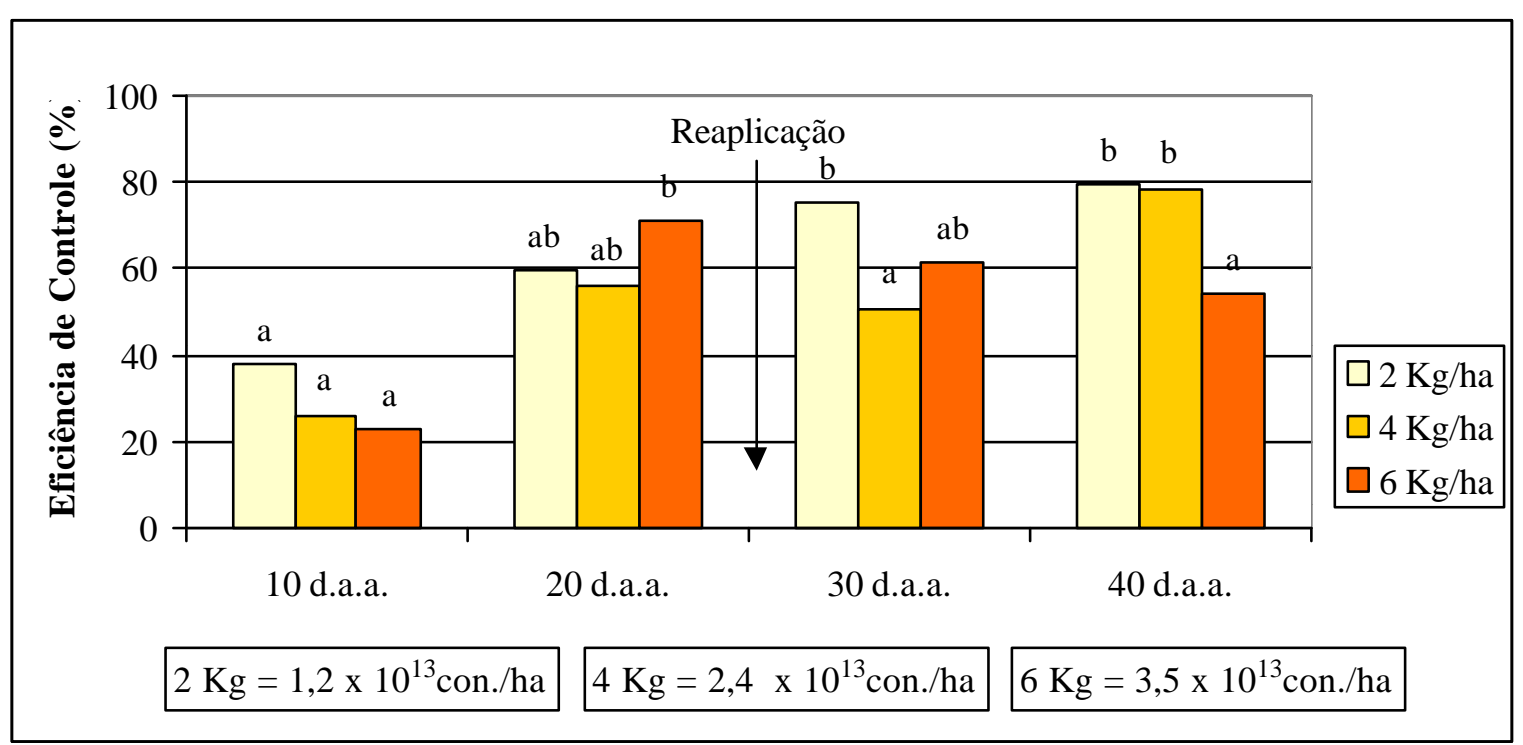

Figura 14- Eficiência de Beauveria bassiana, isolado 1196, no controle de adultos de Leptopharsa heveae em (Caçú-GO, 2001). 


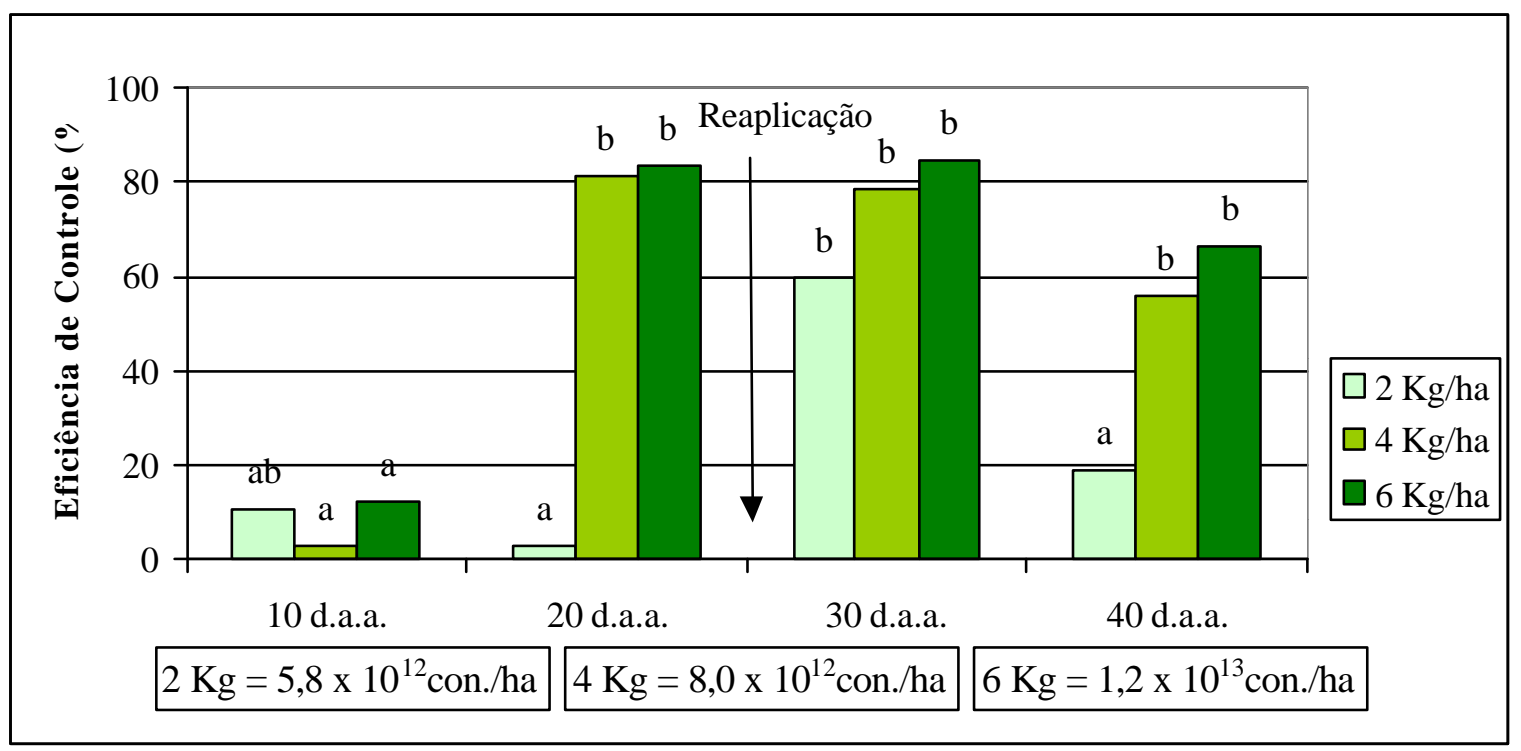

Figura 15- Eficiência de Metarhizium anisopliae, isolado 1104, no controle de ninfas de Leptopharsa heveae (Caçú-GO, 2001).

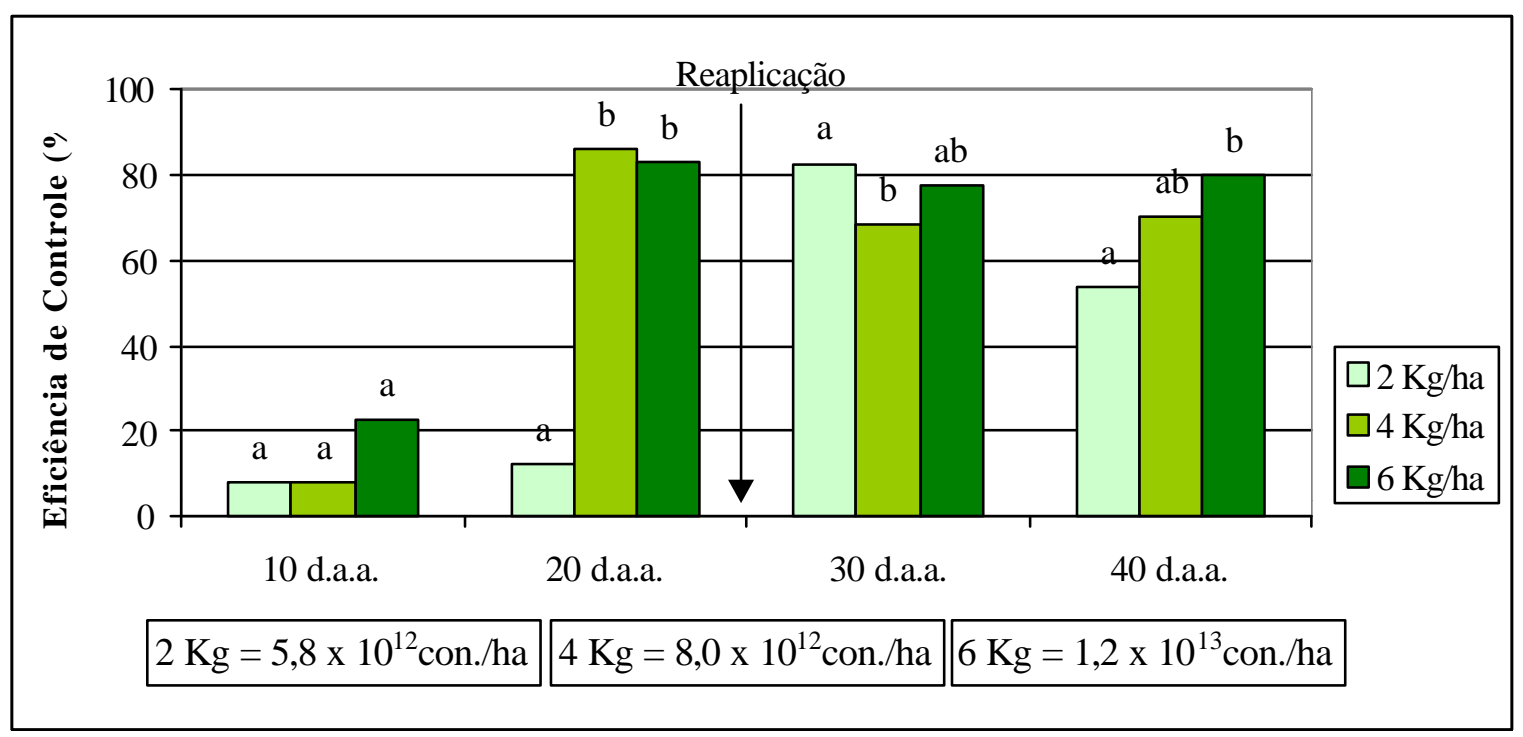

Figura 16- Eficiência de Metarhizium anisopliae, isolado 1104, no controle de ninfas de Leptopharsa heveae (Caçú-GO, 2001). 
Assim, nas duas regiões avaliadas, as concentrações superiores a $4 \mathrm{Kg} / \mathrm{ha}$, ou maiores que $8 \times 10^{12}$ conídios/ha, podem ser consideradas eficientes para o controle de ninfas e adultos de L. heveae.

A utilização destes produtos por heveicultores, com essa elevada concentração de conídios torna-se praticamente inviável devido ao baixo preço da borracha no mercado internacional. As formulações encontradas atualmente no mercado, Boveril (B. bassiana) e Metarril (M. anisopliae) custam aproximadamente U\$ 8,00/Kg (U\$ 1,00 = R \$2,50) e, portanto, somente o custo do produto para um hectare, na menor concentração, seria de aproximadamente U\$ 32,00.

\subsubsection{Avaliação de diferentes espécies de fungos no controle de Leptopharsa heveae na cultura da seringueira}

Os resultados obtidos em Caçú, para ninfas, apresentaram diferenças significativas entre os tratamentos somente aos 20 dias após a aplicação (d.a.a.). Nesse período os fungos mais eficientes foram M. anisopliae (1144), P. fumosoroseus (1200) e B. bassiana (1196), com 66, 53 e $48 \%$ de mortalidade, respectivamente. A menor eficiência foi obtida com $S$. insectorum (1229) e os outros fungos causaram mortalidade igual e inferior a $20 \%$. Nas avaliações posteriores a 30 e 40 d.a.a., os tratamentos não diferiram entre si, provavelmente devido a redução da população na testemunha, cuja infestação foi de aproximadamente 6 e 11 insetos, respectivamente, sendo que com 20 d.a.a., a infestação era de 27 insetos (Tabela $8)$.

Para a avaliação de adultos vivos do percevejo-de-renda-da-seringueira, foram verificadas diferenças significativas entre os tratamentos aos 20 e 30 d.a.a. As melhores eficiências foram obtidas com M. anisopliae (1189) conseguindo-se 52\% de mortalidade, seguido de M. anisopliae (1144) com 48\% e V. lecanii (972) com 39\% com 20 d.a.a. Já aos 30 d.a.a., não foi observada mortalidade, possivelmente devido ao mesmo fato que ocorreu com as ninfas; sendo que a população da testemunha reduziu de sete para um adulto/folha. Essa redução pode ter sido devido à disseminação do fungo pela dispersão de insetos contaminados da área tratada para a testemunha. $\mathrm{O}$ tratamento que apresentou menor 
eficiência nessas avaliações foi $S$. insectorum (1229), no qual a infestação foi maior que nos outros tratamentos, apesar do isolado aplicado ter sido obtido do próprio percevejo-derenda-da-seringueira e portanto, seu hospedeiro natural (Tabela 9).

Pode-se observar que em Caçú, tanto para ninfas como para adultos, os fungos que apresentaram melhores resultados foram M. anisopliae (1144) e B. bassiana (1196) (Figura 17). Esses resultados confirmaram o largo espectro desses patógenos, pois o primeiro foi isolado de Calosoma granulatum obtido em Piracicaba- SP e o segundo de uma amostra de solo de Corumbá- MS.

A não especificidade desses isolados, por outro lado, pode ser prejudicial devido a ação sobre inimigos naturais, como foi observado por Danfa \& van der Valk (1999), que estudaram o efeito de Metarhizum spp. e Beauveria spp. sobre braconídeos e encirtídeos, verificando $100 \%$ de mortalidade desses insetos. Em condições de campo, Reyes et al. (1995) observaram que B. bassiana e M. anisopliae causaram, respectivamente, $24 \%$ e $5 \%$ de mortalidade ao parasitóide Cephalonomia stephanoderis. Sobre Ceraeochrysa cincta (Chrysopidae), um predador de L. heveae, testou-se a ação de $S$. insectorum, não verificando efeito sobre ovos, larvas do $2^{\circ}, 3^{\circ}$ ínstar, pupas e adultos e pouca toxicidade para larvas do $1^{\text {o }}$ ínstar (Tanzini, 1997; Scomparin,1997).

No primeiro ensaio de Itiquira, as avaliações de ninfas e adultos de L. heveae vivos, não diferiram estatisticamente entre os tratamentos com 5 e 10 d.a.a. (Tabelas 10 e 11). Foi utilizado o fungo B. bassiana (447) devido a facilidade de produção desse inóculo, pois o isolado selecionado 1196, apresentou contaminações. Para ninfas, a mortalidade variou de 31 a $45 \%$ e para adultos esses valores foram de 6 a 52\% (Figuras 18 e 19). Provavelmente, essas diferenças podem ser atribuídas ao curto período de avaliação. Mesmo assim, os resultados com P. fumosoroseus (1200) foram considerados satisfatórios em condições de campo.

Outro fator a considerar é o período e método de armazenamento desses fungos. Essa é uma região onde ocorrem oscilações de energia deixando os freezers muito tempo desligados, o que interfere na viabilidade desses patógenos. Segundo Alves et al., (1995) 
Tabela 8. Número de ninfas vivas de Leptopharsa heveae por folha, observadas nos tratamentos com fungos (Caçú-GO, 2001).

\begin{tabular}{lcccccc}
\hline & Prévia & 10 d.a.a. & 20 d.a.a. & (\%) EF & 30 d.a.a. & 40 d.a.a. \\
\hline Testemunha & 24,44 & 23,55 & 27,35 a & - & 5,96 & 10,87 \\
Beauveria bassiana (1196) & 17,85 & 21,12 & 10,38 bc & 48,04 & 7,45 & 11,63 \\
Beauveria brongniartii (619) & 14,00 & 16,56 & 13,13 bc & 16,19 & 5,39 & 15,81 \\
Metarhizium anisopliae (1144) & 18,66 & 19,70 & 7,11 c & 65,95 & 9,74 & 15,98 \\
Metarhizium anisopliae (1189) & 9,14 & 11,55 & 8,17 c & 20,12 & 9,36 & 12,37 \\
Paecilomyces fumosoroseus (1200) & 23,01 & 26,07 & 12,06 bc & 53,16 & 11,03 & 13,19 \\
Sporothrix insectorum (1229) & 16,21 & 20,23 & 18,17 ab & 0,00 & 10,59 & 11,07 \\
Verticillium lecanii (972) & 11,43 & 14,16 & 11,25 bc & 12,05 & 4,34 & 11,70 \\
\hline \multicolumn{1}{c}{ F } & 1,19 n.s. & 1,28 n.s. & $9,35 *$ & & 1,82 n.s. & 1,15 n.s. \\
\multicolumn{1}{c}{ C.V.(\%) } & 51,55 & 24,65 & 35,57 & & 52,8 & 32,9 \\
\hline
\end{tabular}

Tabela 9. Número de adultos vivos de Leptopharsa heveae por folha, observados nos tratamentos com fungos (Caçú-GO, 2001).

\begin{tabular}{|c|c|c|c|c|c|c|c|}
\hline & Prévia & 10 d.a.a. & 20 d.a.a. & $(\%) \mathrm{EF}$ & 30 d.a.a. & $(\%) \mathrm{EF}$ & 40 d.a.a. \\
\hline Testemunha & 7,18 & 8,18 & $7,51 \mathrm{ab}$ & & $1,05 \mathrm{~b}$ & & 1,92 \\
\hline Beauveria bassiana (1196) & 6,72 & 7,59 & $4,31 \mathrm{bc}$ & 38,68 & $2,20 \mathrm{ab}$ & 0,00 & 2,71 \\
\hline Beauveria brongniartii (619) & 6,40 & 6,94 & $4,46 \mathrm{bc}$ & 33,37 & $1,97 \mathrm{ab}$ & 0,00 & 1,73 \\
\hline Metarhizium anisopliae (1144) & 6,94 & 7,54 & $3,75 \mathrm{c}$ & 48,34 & $2,53 \mathrm{ab}$ & 0,00 & 2,80 \\
\hline Metarhizium anisopliae (1189) & 5,83 & 5,44 & $2,94 \mathrm{c}$ & 51,79 & $1,86 \mathrm{ab}$ & 0,00 & 2,36 \\
\hline Paecilomyces fumosoroseus (1200) & 6,37 & 7,48 & $6,51 \mathrm{abc}$ & 2,29 & $2,45 \mathrm{ab}$ & 0,00 & 2,21 \\
\hline Sporothrix insectorum (1229) & 7,94 & 9,16 & $10,23 \mathrm{a}$ & 0,00 & $2,85 \mathrm{a}$ & 0,00 & 1,83 \\
\hline Verticillium lecanii (972) & 5,98 & 6,81 & $3,79 \mathrm{bc}$ & 39,41 & $1,55 \mathrm{ab}$ & 0,00 & 1,92 \\
\hline $\mathrm{F}$ & 0,34 n.s. & 1,07 n.s. & $9,13 *$ & & $3,14 *$ & & 1,41 n.s. \\
\hline C.V. $(\%)$ & 39,26 & 31,53 & 33,5 & & 35,52 & & 35,07 \\
\hline
\end{tabular}




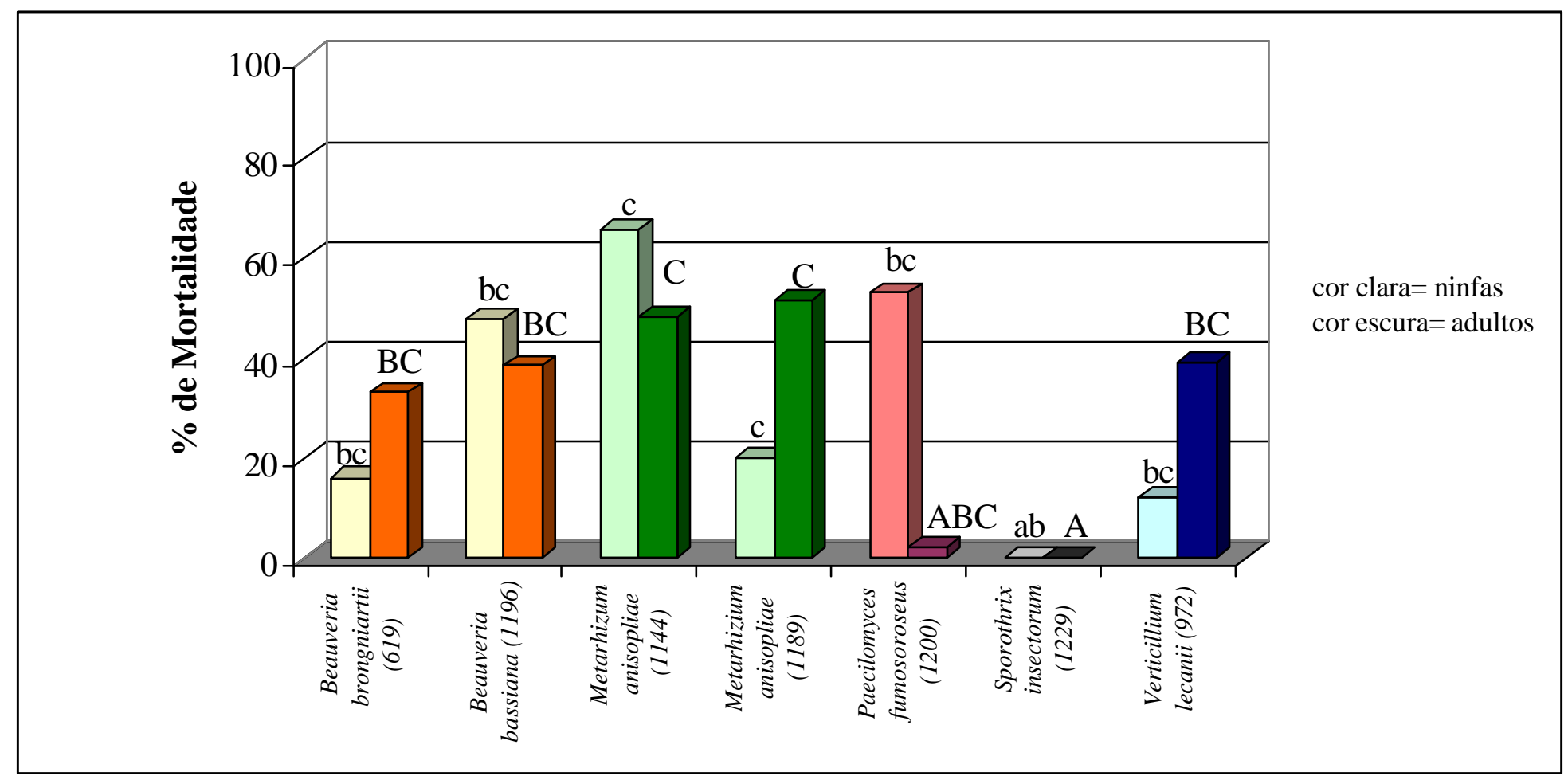

Figura 17- Mortalidade de ninfas e adultos de Leptopharsa heveae, causada pelos fungos entomopatogênicos 20 dias após tratamento (Caçú-GO, 2001). 
Tabela 10. Número de ninfas vivas de Leptopharsa heveae por folha, observadas nos tratamentos com fungos entomopatogênicos em (Itiquira- MT, 2001).

\begin{tabular}{lccc}
\hline & Prévia & 5 d.a.a. & 10 d.a.a. \\
\hline Testemunha & 7,69 & 16,21 & 22,24 \\
Beauveria bassiana (447) & 10,75 & 12,69 & 17,74 \\
Paecilomyces fumosoroseus (1200) & 11,56 & 13,34 & 21,95 \\
Sporothrix insectorum (1229) & 9,00 & 13,09 & 16,64 \\
\hline F & 2,20 n.s. & 1,46 n.s. & 2,74 n.s. \\
C.V.(\%) & 48,11 & 38,53 & 35,29 \\
\hline
\end{tabular}

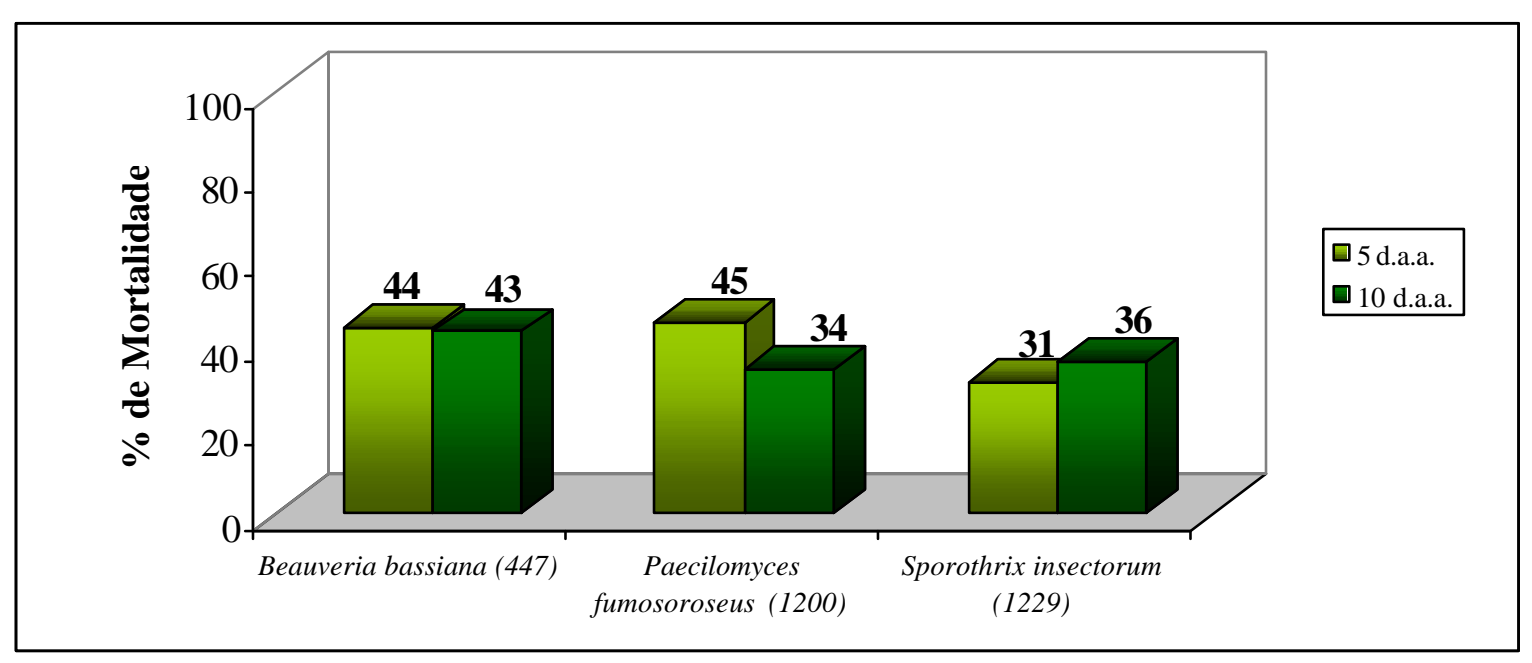

Figura 18- Mortalidade de ninfas de Leptopharsa heveae aos 5 e 10 dias após aplicação de fungos entomopatogênicos (Itiquira- MT, 2001). 
Tabela 11. Número de adultos de Leptopharsa heveae vivos por folha, nos tratamentos com fungos entomopatogênicos (Itiquira- MT, 2001).

\begin{tabular}{|c|c|c|c|c|}
\hline & Prévia & & 5 d.a.a. & 10 d.a.a. \\
\hline Testemunha & 1,19 & $\mathrm{~b}$ & 3,27 & 4,48 \\
\hline Beauveria bassiana (447) & 2,00 & $a b$ & 2,56 & 4,01 \\
\hline Paecilomyces fumosoroseus (1200) & 2,87 & $\mathrm{a}$ & 2,89 & 4,83 \\
\hline Sporothrix insectorum (1229) & 1,37 & $\mathrm{~b}$ & 2,29 & 3,71 \\
\hline $\mathrm{F}$ & $4,88^{*}$ & & $1,81 \mathrm{n} . \mathrm{s}$. & 0,35 n.s. \\
\hline C.V. $(\%)$ & 74,11 & & 45,94 & 40,49 \\
\hline
\end{tabular}

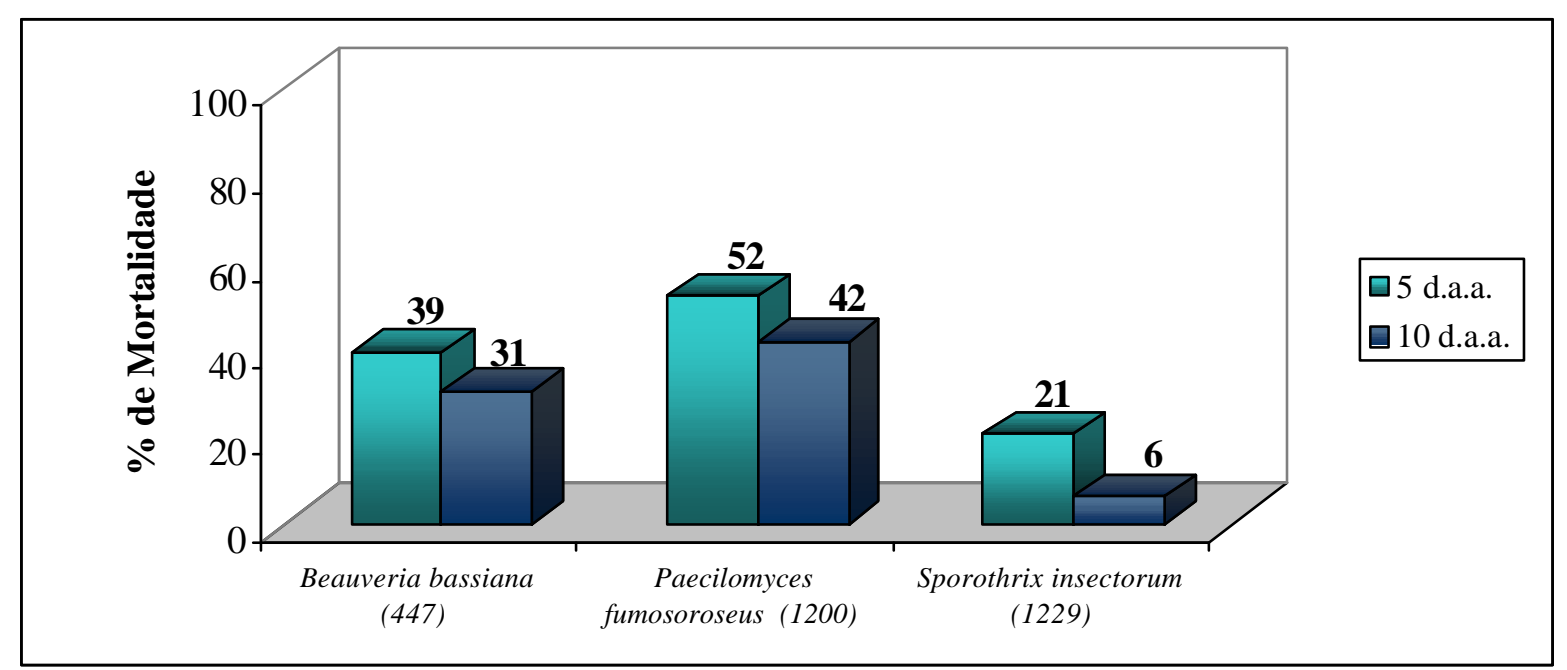

Figura 19- Mortalidade de adultos de Leptopharsa heveae, aos 5 e 10 dias após aplicação de fungos entomopatogênicos (Itiquira-MT, 2001). 
conídios de B. bassiana armazenados em geladeira, por sete anos, germinaram no período de 72 a 96 horas sob temperatura de $26^{\circ} \mathrm{C}$, enquanto conídios não armazenados ou armazenados em freezer germinaram entre 18 e 24 horas. Os autores também observaram que os conídios armazenados em geladeira, apesar de apresentarem 100\% de viabilidade, causaram somente $20 \%$ de mortalidade em larvas de Diatraea saccharalis, enquanto os não armazenados ou armazenados em freezer causaram mortalidade de $100 \%$.

No segundo ensaio realizado para ninfas de L. heveae em Itiquira (Tabela 12), somente aos 10 d.a.a. não houve diferença significativa entre os tratamentos, sendo as eficiências superiores a 49\%, consideradas satisfatórias a partir de 6 d.a.a., devido ao tratamento testemunha ter apresentado um crescimento de 4 ninfas/folha na avaliação prévia a 42 insetos/folha aos 20 d.a.a. Apesar das eficiências serem semelhantes ao ensaio realizado em condições de laboratório, no último dia de avaliação os fungos $M$. anisopliae (1175 e 1184) e P. fumosoroseus (1200), que causaram maiores mortalidades, ainda apresentavam um alto número de insetos/folha, segundo a classificação proposta por Tanzini (1997). Essa população pode ter atingido níveis considerados baixos com o decorrer do tempo, como mostra a tendência de decréscimo das populações tratadas com esses fungos (Figura 20).

Esse aumento da população entre as avaliações de 10 e 20 d.a.a. foi devido a eclosão de ninfas, e provavelmente os fungos não tiveram efeito ovicida, pois as posturas endofíticas são difíceis de serem atingidas pelos fungos, Tanzini \& Lara (1998). Nesse mesmo trabalho os autores citaram que o período de incubação médio foi de 12 dias no clone PB 235, a duração do período ninfal de 15 dias e adulto de 21 dias.

Para o controle de adultos do segundo ensaio realizado em Itiquira, houve diferença significativa até 10 d.a.a. entre os tratamentos, igualando todos aos 20 d.a.a. (Tabela 13). Houve uma melhor performance dos isolados de $M$. anisopliae (1175) e B. bassiana (447) (Figura 21), ao contrário de M. anisopliae (E9) que apresentou uma melhor eficiência aos 6 d.a.a., permanecendo inalterada a população do inseto no decorrer do ensaio. Esses resultados podem estar relacionados a dispersão dos adultos, o que não acontece com as ninfas, razão também pela escolha de se efetuar os ensaios com esse estágio na fase de seleção de isolados. Houveram também problemas na multiplicação dos isolados selecionados de M. anisopliae (E6 e 1144) e B. bassiana (1196), mas cabe 
Tabela 12. Número de ninfas vivas de Leptopharsa heveae por folha observadas nos tratamentos com fungos entomopatogênicos (Itiquira- MT, 2001).

\begin{tabular}{|c|c|c|c|c|c|c|c|}
\hline & Prévia & 6 d.a.a. & $(\%) \mathrm{EF}$ & 10 d.a.a. & $(\% \mathrm{EF})$ & 20 d.a.a. & $(\%) \mathrm{EF}$ \\
\hline Testemunha & 3,92 & 7,28 & - & 8,13 & - & $41,67 \mathrm{a}$ & - \\
\hline Beauveria bassiana (447) & $27,01 \mathrm{a}$ & 9,23 & 81,60 & 10,47 & 81,31 & 21,55 & 92,49 \\
\hline Metarhizium anisopliae (1175) & $27,54 \mathrm{a}$ & $19,57 \mathrm{a}$ & 61,74 & 11,98 & 79,03 & 8,63 & 97,05 \\
\hline Metarhizium anisopliae (1184) & $22,62 \mathrm{ab}$ & $15,98 \mathrm{ab}$ & 61,96 & 11,05 & 76,45 & 8,67 & 96,39 \\
\hline Metarhizium anisopliae (E9) & $12,68 \quad \mathrm{c}$ & 11,80 bcd & 49,89 & 10,54 & 59,92 & $33,33 \quad b$ & 75,27 \\
\hline Paecilomyces fumosoroseus (1200) & 27,06 a & $13,94 \mathrm{bc}$ & 72,26 & 12,00 & 78,62 & 12,71 & 95,58 \\
\hline Sporothrix insectorum (1229) & $16,83 \quad b c$ & 11,16 bcd & 64,29 & 11,42 & 67,28 & $28,18 \quad b c$ & 84,25 \\
\hline $\mathrm{F}$ & $39,47 *$ & $12,52^{*}$ & & 1,19n.s. & & $59,10^{*}$ & \\
\hline C.V.(\%) & 12,7 & 30,01 & & 37,38 & & 25,81 & \\
\hline
\end{tabular}

Tabela 13. Número de adultos vivos de Leptopharsa heveae por folha observados nos tratamentos com fungos entomopatogênicos (Itiquira- MT, 2001).

\begin{tabular}{|c|c|c|c|c|c|c|c|}
\hline & Prévia & 6 d.a.a. & $(\%) \mathrm{EF}$ & 10 d.a.a. & $(\%) \mathrm{EF}$ & 20 d.a.a. & $(\%) \mathrm{EF}$ \\
\hline Testemunha & $5,90 \mathrm{ab}$ & $11,98 \mathrm{abc}$ & - & $8,30 \mathrm{a}$ & - & 5,38 & - \\
\hline Beauveria bassiana (447) & $6,32 \mathrm{ab}$ & $13,67 \mathrm{ab}$ & 0,00 & $7,87 \mathrm{a}$ & 11,48 & 4,62 & 19,83 \\
\hline Metarhizium anisopliae (1175) & $7,25 \mathrm{a}$ & $14,80 \mathrm{a}$ & 0,00 & 7,18 a & 29,60 & 4,43 & 32,99 \\
\hline Metarhizium anisopliae (1184) & $5,18 \mathrm{ab}$ & $11,98 \mathrm{abc}$ & 0,00 & $7,37 \mathrm{a}$ & 0,00 & 4,45 & 5,79 \\
\hline Metarhizium anisopliae (E9) & $3,97 \quad b$ & 4,70 & 41,70 & $4,93 \quad b$ & 11,73 & 4,43 & 0,00 \\
\hline Paecilomyces fumosoroseus (1200) & $5,43 \mathrm{ab}$ & 11,17 bc & 0,00 & 8,17 a & 0,00 & 5,15 & 0,00 \\
\hline Sporothrix insectorum (1229) & $3,75 \quad b$ & 9,43 & 0,00 & $6,97 \mathrm{ab}$ & 0,00 & 5,52 & 0,00 \\
\hline $\mathrm{F}$ & $4,28 *$ & $17,52 *$ & & $5,17 *$ & & $1,50 \mathrm{n} . \mathrm{s}$ & \\
\hline C.V.(\%) & 38,65 & 24,63 & & 23,91 & & 27,94 & \\
\hline
\end{tabular}




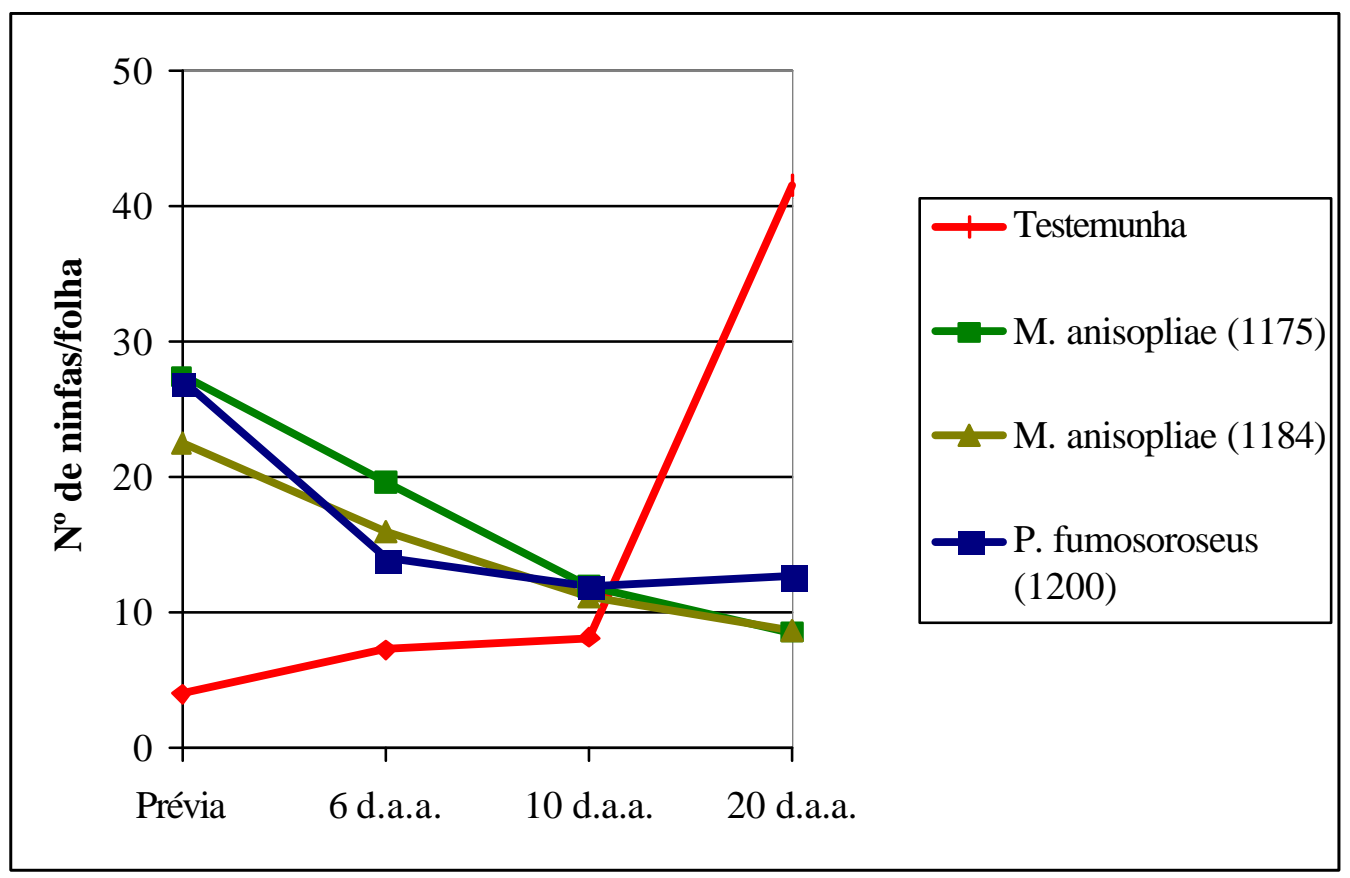

Figura 20- Número de ninfas de Leptopharsa heveae/folha nas avaliações prévia, 6, 10 e 20 dias após aplicação com diferentes fungos entomopatogênicos (Itiquira-MT, 2001).

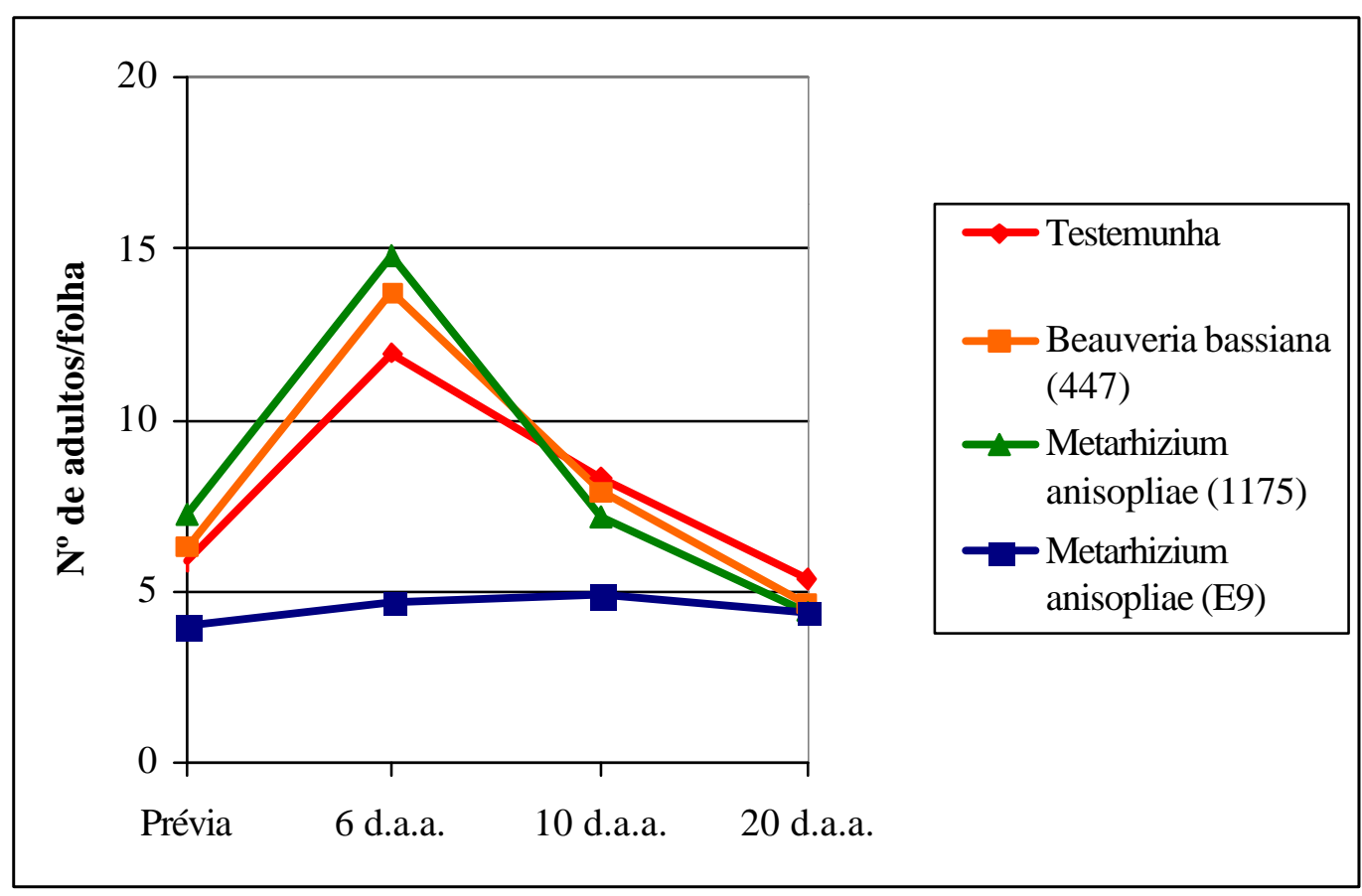

Figura 21- Número de adultos de Leptopharsa heveae/folha nas avaliações prévia, 6, 10 e 20 dias após aplicação com diferentes fungos entomopatogênicos (Itiquira-MT, 2001). 
ressaltar que esses fungos utilizados mostraram eficiências acima de $95 \%$ em condições de laboratório.

Essa diferença na suscetibilidade entre fases de desenvolvimento do inseto, pode ser um aspecto favorável, no caso de maior infecção em ninfas, pela formação rápida dos focos primários que são necessários para a doença assumir caráter epizoótico, principalmente na cultura da seringueira que é perene. Alves \& Lecuona (1998) mostraram que Trichoplusia ni foi mais sensível a Nomuraea rileyi nos primeiros ínstares, ocorrendo o inverso com largartas de Anticarsia gemmatalis, as quais apresentaram ser menos suscetíveis nos dois primeiros ínstares. No caso da infecção de adultos, estes podem contribuir para a maior produção de propágulos e disseminação a longas distâncias, o que pode ter sido um dos motivos para as baixas eficiências sobre insetos neste estágio. Outra explicação para esses resultados é que a seleção de isolados em laboratório foi realizada com ninfas e em condições de campo pode ocorrer sobreposição de gerações.

\subsection{Conclusões}

- $\quad$ No controle de Leptopharsa heveae com Beauveria bassiana e Metarhizium anisopliae em condições de campo devem ser usadas as concentrações iguais ou superiores a $4 \mathrm{Kg}$ de fungo/ha contendo $10^{12}$ e $10^{13}$ conídios/ha, respectivamente.

- $\quad$ As eficiências de mortalidade são comumente observadas a partir dos 20 dias após aplicação em Itiquira-MT e Caçú-GO.

- $\quad$ Os fungos P. fumosoroseus (1200), B. bassiana (447) e M. ansiopliae (1175

e 1144) são os mais eficientes para controle de L. heveae. 


\section{TOXICIDADE DE PRODUTOS FITOSSANITÁRIOS UTILIZADOS NO CONTROLE DE Leptopharsa heveae PARA FUNGOS ENTOMOPATOGENICOS}

\section{RESUMO}

Avaliou-se o efeito tóxico "in vitro" de seis produtos fitossanitários utilizados para controle de $L$. heveae na cultura da seringueira sobre os fungos B. brongniartii (619); $V$. lecanii (972); M. anisopliae (1144 e 1189); P. fumosoroseus (1200), S. insectorum (1229) e B. bassiana (1196). Os produtos foram adicionados em concentrações proporcionais às que são utilizadas em condições de campo em meio de cultura BDA, quando este ainda encontrava-se em estado líquido, sob a temperatura de, aproximadamente, $50^{\circ} \mathrm{C}$. Após a solidificação do meio em placa de Petri, foi feita a inoculação dos microrganismos, em três pontos por placa. Decorridos 10 dias, as placas foram retiradas da incubação (câmara tipo BOD, com $26 \pm 0,5^{\circ} \mathrm{C}, 70 \pm 10 \%$ UR e fotofase de 12 horas), fazendo-se a avaliação do diâmetro médio das colônias e da produção de conídios. Decis e Nuvacron foram compatíveis com B. brongniartii (619). A maioria das combinações, com exceção da formulação de Decis foi compatível com V. lecanii (972). O fungo M. anisopliae (1144) foi muito sensível para todas as formulações, com exceção do isolado 1189, que não foi suscetível às formulações de triclorfon, carbosulfan e metamidofós, o que mostra a variabilidade genética de uma mesma espécie de fungo. Nuvacron e Stron foram compatíveis com B. bassiana (1196), P. fumosoroseus (1200) e S. insectorum (1229). Marshal foi compatível com B. bassiana (1196) e S. insectorum (1229) e Dipterex foi compatível com P. fumosoroseus (1200). 


\section{TOXICITY OF PHYTOSSANITARY PRODUCTS USED FOR THE CONTROL OF Leptopharsa heveae TO ENTOMOPATHOGENIC FUNGI}

\section{SUMMARY}

The toxic effects of six phytossanitary products used for control of L. heveae were evaluated "in vitro" on the fungi Beauveria brongniartii (619); Verticillium lecanii (972); Metarhizium anisopliae (1144 and 1189); Paecilomyces fumosoroseus (1200), Sporothrix insectorum (1229) and B. bassiana (1196). The products were added to culture media (PDA) in concentrations similar to those used in field conditions. Products were added to the liquid medium at approximately $50^{\circ} \mathrm{C}$. After the solidification of the media in Petri dish, the microorganisms were inoculated at three points/dish. After incubation for 10 days (BOD, with $26 \pm 0.5^{\circ} \mathrm{C}, 70 \pm 10 \% \mathrm{RU}$ and photophase of 12 hours), the average diameter of the colonies and of the conidia yield were measured. Decis and Nuvacron were compatible with B. brongniartii (619). Most of the combinations, except Decis, were compatible with $V$. lecanii (972). The fungus $M$. anisopliae (1144) was very sensitive for all of the formulations, except for isolated 1189, which was not affected by triclorfon, carbosulfan and metamidophos, demonstrating the genetic variability of isolates of a fungal species. Nuvacron and Stron were compatible with B. bassiana (1196), P. fumosoroseus (1200) and S. insectorum (1229). Marshal was compatible with B. bassiana (1196) and S. insectorum (1229), and Dipterex was compatible with P. fumosoroseus (1200).

\subsection{Introdução}

O Manejo Integrado de Pragas (MIP) encoraja a diminuição da utilização de pesticidas químicos e fornece várias opções de se controlar a praga harmoniosamente, fazendo com que esta permaneça em baixos níveis populacionais e assim não causem danos econômicos à cultura (Papacek \& Smith, 1994). 
O controle biológico está dentre as opções preconizadas pelo MIP, utilizando agentes biológicos; como predadores, parasitóides e entomopatógenos. Muitas vezes, os fungos para serem utilizados no controle microbiano como inseticidas biológicos, não estão disponíveis em grandes quantidades e faz-se necessário o uso de produtos fitossanitários para a redução da população de $L$. heveae.

A aplicação desses pesticidas sobre os entomopatógenos pode variar em função da espécie e linhagem do patógeno, da natureza química dos produtos e das concentrações utilizadas. Esses produtos podem atuar inibindo o crescimento vegetativo, a conidiogênese e a esporulação dos microrganismos, e até causando mutações genéticas, as quais podem levar a diminuição da virulência a determinada praga. Sendo assim, é necessária a utilização de produtos seletivos que não afetem o equilíbrio entre as pragas e seus predadores, parasitos e patógenos, responsáveis pelo controle biológico natural, que mantém as pragas em níveis populacionais aceitáveis (Alves, 1998b). Portanto, torna-se necessário a aplicação racional de produtos químicos que venham a favorecer as formas alternativas de controle de pragas, baseando-se na preservação dos inimigos naturais existentes no agroecossistema.

Diversas formulações foram avaliadas quanto ao efeito tóxico sobre Bacillus thuringiensis, M. anisopliae e Aspergillus sp. por Alves (1978). O efeito de alguns produtos químicos sobre Atractium flammeum, Hirsutella thompsonii, V. lecanii e Aschersonia aleyrodis foram estudados por Alves et al.(1993) os quais concluíram que Torque 500 SC, Danimen 300 CE e Morestan 50 SC foram os mais seletivos aos fungos estudados.

A variabilidade genética natural entre isolados de uma mesma espécie de fungo entomopatogênico é bastante conhecida e relatada. Esta variabilidade também ocorre para a sensibilidade a produtos químicos. Assim, Todovora (1998) procurou explicar as diferentes respostas de B. bassiana com um mesmo produto químico.

Alves et al. (1998) apresentaram diversas tabelas de compatibilidade e demonstraram que a toxicidade de um produto pode estar relacionada com sua concentração e tipo de formulação em que o princípio ativo foi preparado. Existem produtos que são muito tóxicos mesmo em concentrações muito reduzidas. 
Assim, a simples utilização de produtos fitossanitários compatíveis a esses entomopatógenos representa uma estratégia prática e econômica que contribui para a proteção dos entomopatógenos e equilíbrio do ambiente.

O objetivo desse trabalho é conhecer o efeito tóxico de algumas formulações de produtos fitossanitários utilizados na heveicultura para controle de L. heveae, aos fungos entomopatogênicos selecionados para controle do inseto e assim elaborar com segurança uma estratégia eficiente de manejo ecológico dessa praga.

\subsection{Material e Métodos}

Foram avaliados os efeitos tóxicos "in vitro" de diversos produtos fitossanitários utilizados na cultura da seringueira sobre os fungos Beauveria brongniartii (619); V. lecanii (972); M. anisopliae (1144 e 1189); P. fumosoroseus (1200), S. insectorum (1229) e B. bassiana (1196). Esses fungos foram selecionados, em condições de laboratório, para controle de L. heveae.

Os produtos foram adicionados em concentrações pré estabelecidas (Tabela 14), em meio de cultura BDA (Batata-Dextrose-Ágar), quando este ainda encontrava-se em estado líquido, sob a temperatura de, aproximadamente, $50^{\circ} \mathrm{C}$. Após a solidificação do meio em placa de Petri, foi feita a inoculação dos microrganismos com alça de platina, em três pontos por placa, eqüidistantes entre si, para evitar o contato entre as colônias.

Tabela 14. Produtos fitossanitários utilizados nos ensaios de compatibilidade com os fungos entomopatogênicos selecionados para controle de Leptopharsa heveae.

\begin{tabular}{lllll}
\hline Produto Comercial* & Ingrediente Ativo & Concentração & \multicolumn{1}{c}{ Classe } & \multicolumn{1}{c}{ Grupo } \\
\hline Decis 25 CE & Deltametrina & $0,2 \mathrm{~L} / \mathrm{ha}$ & Inseticida & Piretróide \\
Dipterex 500 & Triclorfon & $0,9 \mathrm{~L} / \mathrm{ha}$ & Inseticida & Organosfosforado \\
Nuvacron & Monocrotofós & $0,4 \mathrm{~L} / \mathrm{ha}$ & Inseticida/ acaricida & Organosfosforado \\
Marshal 200 SC & Carbosulfan & $0,15 \mathrm{~L} / \mathrm{ha}$ & Acaricida & Carbamato \\
Stron & Metamidofós & $1,0 \mathrm{~L} / \mathrm{ha}$ & Inseticida/acaricida & Organofosforado \\
Karate 50 CE & Lambdacyhalothrin & $0,45 \mathrm{~L} / \mathrm{ha}$ & Inseticida & Piretróide \\
\hline *- Esses produtos não são registrados para 0 controle de Leptopharsa heveae e nem para a cultura da \\
\multicolumn{4}{l}{ seringueira. Foram escolhidos, por serem utilizados na prática para o controle desse inseto e de ácaros em } \\
várias regiões heveícolas (Andrei, 1999).
\end{tabular}


A avaliação do efeito tóxico foi feita pela observação do crescimento vegetativo e da produção de conídios das colônias dos fungos na superfície do meio de cultura. Ao final de um período de 10 dias, as placas foram retiradas da incubação (câmara tipo BOD, com temperatura $26 \pm 0,5^{\circ} \mathrm{C}$, fotofase de 12 horas e umidade relativa de $70 \pm 10 \%$ ), avaliando-se o diâmetro médio das colônias. Foram feitas nove inoculações por tratamento, sendo consideradas na avaliação as cinco colônias mais uniformes. Em seguida, essas colônias foram recortadas junto com o meio de cultura e transferidas para tubos de vidro com água destilada estéril. Os conídios foram retirados com auxílio de uma espátula de borracha sendo preparadas uma série de diluições sucessivas para a obtenção de uma suspensão que permitiu a contagem dos conídios por meio de câmara de Neubauer.

Para a classificação de toxicidade da formulação foi utilizado o modelo proposto por Alves et al. (1998).

$$
\mathrm{T}=\frac{20[C V]+80[E S P]}{100}
$$

Onde:

T: valor corrigido do crescimento vegetativo e da esporulação para classificação do produto;

$\mathrm{CV}$ : porcentagem de crescimento vegetativo com relação à testemunha;

ESP: porcentagem de esporulação com relação à testemunha.

A partir dos valores calculados de T, procedeu-se a comparação com os limites estabelecidos na Tabela 15.

Tabela 15. Classificação da toxicidade de produtos químicos sobre fungos entomopatogênicos (Alves et al., 1998).

\begin{tabular}{cc}
\hline Valor de $\mathbf{T}$ & Classificação do Produto \\
\hline 0 a 30 & Muito tóxico \\
31 a 45 & Tóxico \\
46 a 60 & Moderadamente tóxico \\
$>60$ & Compatível \\
\hline
\end{tabular}




\subsection{Resultados e Discussão}

As formulações de deltametrina (Decis) e monocrotofós (Nuvacron) foram compatíveis com B. brongniartii (619). A maioria das combinações, com exceção da formulação de Decis foi compatível com V. lecanii (972). O fungo M. anisopliae (1144) foi muito sensível para todas as formulações. Já outro isolado de M. anisopliae (1189) não foi suscetível com às formulações dos produtos triclorfon, carbosulfan e metamidofós, o que mostra a variabilidade genética de uma mesma espécie de fungo. As formulações de monocrotofós e metamidofós foram compatíveis com B. bassiana (1196), P. fumosoroseus (1200) e S. insectorum (1229). A formulação de carbosulfan foi compatível com $B$. bassiana (1196) e $S$. insectorum (1229) e a formulação de triclorfon não afetou $P$. fumosoroseus (1200) (Tabela 16 e Figura 22).

Pode-se notar, que para algumas formulações o desenvolvimento em diâmetro foi maior que o da própria testemunha. Fato também observado para o número de conídios/colônia em relação à testemunha. Moino Jr. et al. (1989) avaliaram a ação de produtos fitossanitários utilizados na cultura do citros sobre V. lecanii, B. bassiana e $M$. anisopliae, sendo que, em alguns tratamentos, ocorreu a diminuição do diâmetro médio das colônias, sem alteração no número de conídios produzidos. Esse comportamento pode ser explicado pela presença na formulação de substâncias nutritivas que estimularam a esporulação dos entomopatógenos.

É importante que na classificação quanto a toxicidade, leve-se em consideração além do diâmetro da colônia, o número de conídios. Em estudos futuros poderia se considerar a virulência do patógeno que cresceu no meio com o produto fitossanitário, pois como pode-se observar na Figura 22, na mistura do fungo M. anisopliae (1144) e Decis na concentração de $200 \mathrm{~mL} / \mathrm{ha}$, ocorreram modificações morfológicas na colônia do fungo.

Produtos que proporcionaram crescimento radial das colônias de V. lecanii (972), $P$. fumosoroseus (1200) e S. insectorum (1229), semelhantes à testemunha foram classificados como tóxicos considerando o valor de $\mathrm{T}$ em função desse valor considerar o número de conídios produzidos. 
Tabela 16. Valores T e classificação da toxicidade dos produtos fitossanitários aos isolados de fungos selecionados para controle de Leptopharsa heveae (Piracicaba-SP, 2001).

\begin{tabular}{|c|c|c|}
\hline Tratamentos & Valor $\mathbf{T}$ & Classificação \\
\hline $619+$ deltametrina (Decis) & 88 & Compatível \\
\hline 619 + monocrotofós (Nuvacron) & 144 & Compatível \\
\hline $619+$ triclorfon (Dipterex) & 35 & Tóxico \\
\hline $619+$ carbosulfan (Marshal) & 37 & Tóxico \\
\hline $619+$ metamidofós (Stron) & 35 & Tóxico \\
\hline 619 + lambdacyhalothrin (Karate) & 12 & Muito Tóxico \\
\hline 972 + deltametrina (Decis) & 33 & Tóxico \\
\hline 972 + monocrotofós (Nuvacron) & 61 & Compatível \\
\hline 972 + triclorfon (Dipterex) & 62 & Compatível \\
\hline $972+$ carbosulfan (Marshal) & 77 & Compatível \\
\hline 972 + metamidofós (Stron) & 84 & Compatível \\
\hline $972+$ lambdacyhalothrin (Karate) & 122 & Compatível \\
\hline 1144 + deltametrina (Decis) & 15 & Muito Tóxico \\
\hline 1144 + monocrotofós (Nuvacron) & 18 & Muito Tóxico \\
\hline 1144 + triclorfon (Dipterex) & 24 & Muito Tóxico \\
\hline 1144 + carbosulfan (Marshal) & 19 & Muito Tóxico \\
\hline 1144 + metamidofós (Stron) & 24 & Muito Tóxico \\
\hline 1144 + lambdacyhalothrin (Karate) & 16 & Muito Tóxico \\
\hline 1189 + deltametrina (Decis) & 42 & Tóxico \\
\hline 1189 + monocrotofós (Nuvacron) & 49 & Moderadamente tóxico \\
\hline $1189+$ triclorfon (Dipterex) & 137 & Compatível \\
\hline $1189+$ carbosulfan (Marshal) & 96 & Compatível \\
\hline 1189 + metamidofós (Stron) & 93 & Compatível \\
\hline 1189 + lambdacyhalothrin (Karate) & 56 & Moderadamente tóxico \\
\hline 1196 + deltametrina (Decis) & 32 & Tóxico \\
\hline 1196 + monocrotofós (Nuvacron) & 71 & Compatível \\
\hline 1196 + triclorfon (Dipterex) & 12 & Muito Tóxico \\
\hline 1196 + carbosulfan (Marshal) & 100 & Compatível \\
\hline 1196 + metamidofós (Stron) & 131 & Compatível \\
\hline 1196 + lambdacyhalothrin (Karate) & 22 & Muito Tóxico \\
\hline 1200 + deltametrina (Decis) & 44 & Tóxico \\
\hline 1200 + monocrotofós (Nuvacron) & 157 & Compatível \\
\hline $1200+$ triclorfon (Dipterex) & 180 & Compatível \\
\hline $1200+$ carbosulfan (Marshal) & 39 & Tóxico \\
\hline 1200 + metamidofós (Stron) & 75 & Compatível \\
\hline 1200 + lambdacyhalothrin (Karate) & 53 & Moderadamente tóxico \\
\hline 1229 + deltametrina (Decis) & 32 & Tóxico \\
\hline 1229 + monocrotofós (Nuvacron) & 111 & Compatível \\
\hline 1229 + triclorfon (Dipterex) & 46 & Moderadamente tóxico \\
\hline $1229+$ carbosulfan (Marshal) & 87 & Compatível \\
\hline 1229 + metamidofós (Stron) & 168 & Compatível \\
\hline 1229 + lambdacyhalothrin (Karate) & 25 & Muito Tóxico \\
\hline
\end{tabular}



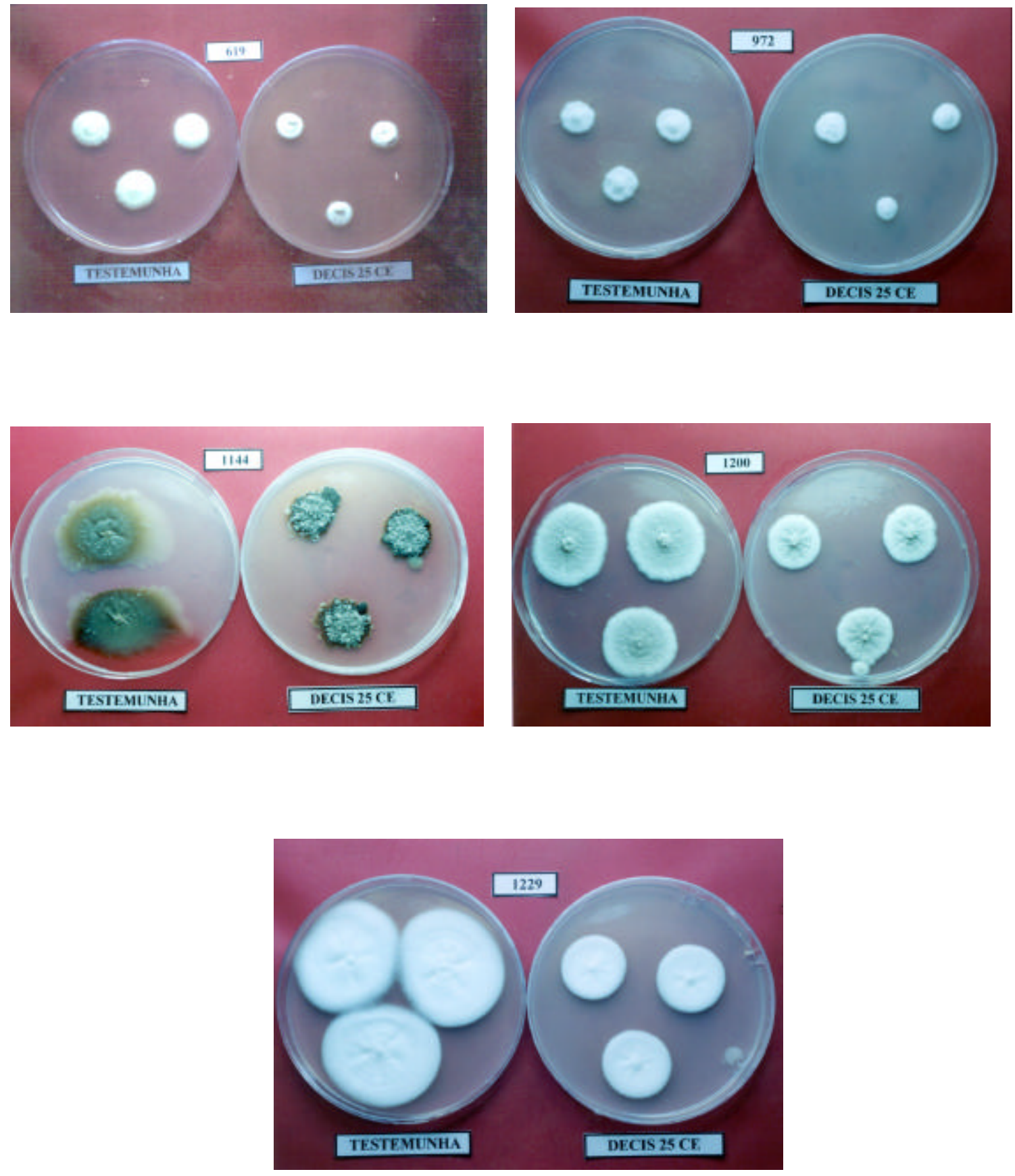

Figura 22- Desenvolvimento de fungos entomopatogênicos na presença de deltametrina (Decis 25 CE) na concentração de 200mL/ha (Piracicaba-SP, 2001). 
Os produtos fitossanitários, podem ser, comercializados em diversas formulações, como é o caso de monocrotofós produzido por várias empresas. Numa pesquisa feita por Anderson \& Roberts (1983), sobre o efeito de formulações sobre B. bassiana, os autores mostraram que os inseticidas formulados como concentrados emulsionáveis foram associados com a inibição da germinação dos conídios, ao contrário das formulações pós molháveis e "flowables"que não causaram inibição e, em alguns casos, favoreceram o crescimento desse patógeno.

Dois experimentos foram conduzidos por Batista Filho et al. (1996) para avaliar a eficiência de fipronil contra Cosmopolites sordidus e a sua compatibilidade com $B$. bassiana. No primeiro experimento, somente fipronil foi eficiente contra adultos de $C$. sordidus. No segundo experimento conduzido em laboratório, os autores concluíram que o fipronil não afetou a viabilidade e a produção de conídios apesar de ter afetado o diâmetro de colônias. As formulações de endosulfan, monocrotofós e deltametrina afetaram $B$. thuringiensis, B. bassiana, M. anisopliae e S. insectorum. (Batista Filho et al. 2000).

A ação dos produtos fitossanitários sobre os entomopatógenos pode variar em função da espécie e linhagem do patógeno, da natureza química dos produtos e das dosagens utilizadas, em alguns casos podem até mesmo causar mutações genéticas nesses entomopatógenos. Esse fato pode levar a formação de mutantes do fungo em condições de campo. Os benefícios e prejuízos decorrentes dessas mutações para o controle microbiano e ambiente são difícieis de serem avaliados, merecendo estudos futuros (Alves et al. 1998).

A ação de fungicidas sobre entomopatógenos é frequentemente tóxica a muito tóxica em relação aos inseticidas e acaricidas. No trabalho de Rebollar et al. (1994), no qual avaliou a compatibilidade de V. lecanii com Manzate 200, Benlate, Captan 50, CupravitMix e Recoil, os autores mostraram que ocorreu a inibição de $100 \%$ do fungo na concetração recomendada. Já os produtos Daconil 2878; Dyrene 50, Rovral 50 e Zineb 80 apresenatram um menor efeito sobre o fungo.

Diversos trabalhos, in vitro, foram realizados visando detectar o efeito de produtos fitossanitários sobre fungos entomopatogênicos (Raramaje et al., 1967; Ignoffo et al., 1975; Alves et al., 1993; Lopez \& Carbonell, 1999). No entanto, ainda faltam pesquisas referentes a essa interação em condições de campo, já que esses trabalhos são difícies de serem realizados em função do grande número de parâmetros que devem ser considerados. 
A compatibilidade com óleos e adjuvantes, visam o desenvolvimento de formulações que mantenham viáveis os fungos por períodos longos. Estudando estratos de Azadirachta indica, Melia azedarach, Pongamia pinnata, Tephrosia purpurea, Parthenium hysterophorus, Cheome viscosa, girassol, côco, semente de algodão, açafroa, nogueira, gergelim com Nomuraea rileyi, Devi \& Prasad (1996) concluíram que nenhum desses produtos foi detrimental ao fungo. Com o mesmo objetivo, Tanzini et al. (2001) estudaram a compatibilidade de doze tensoativos com B. bassiana e M. anisopliae, tendo classificado esses produtos quanto a sua toxicidade para esses fungos.

Ainda de acordo com Alves et al. (1998) os estudos in vitro têm a vantagem de expor ao máximo o microrganismo à ação do produto químico, fato que não ocorre em condições de campo, onde vários fatores servem de obstáculo a essa exposição, protegendo o entomopatógeno. Assim, constatada a inocuidade de um agrotóxico em laboratório, não há dúvidas sobre a sua seletividade em condições de campo.

A atividade química do produto e os vários modos de ação do entomopatógeno tornam o controle associado mais efetivo. Assim, é possível reduzir as concentrações convencionalmente utilizadas dos produtos fitossanitários, sem a diminuição da eficiência do controle.

Com finalidades práticas, Alves (1986) e Alves et al. (1998) publicaram diversas tabelas de compatibilidade entre produtos químicos e entomopatógenos, abrangendo os fungos entomopatogênicos de maior importância no controle microbiano de insetos. Os resultados obtidos nesse experimento complementam esses dados na área de manejo ecológico das pragas da seringueira.

\subsection{Conclusões}

- Os produtos Decis 25 CE (0,2 L/ha) e Nuvacron (0,4L/ha) são compatíveis com Beauveria bassiana (619). 
- O fungo Verticillium lecanii (972) foi compatível com Nuvacron, Dipterex 500 (0,9 L/ha), Marshal $200 \mathrm{SC}(0,15 \mathrm{~L} / \mathrm{ha})$, Stron $(1,0 \mathrm{~L} / \mathrm{ha})$ e Karatê $50 \mathrm{CE}(0,45$ L/ha).

- Todas as formulações testadas são muito tóxicas para Metarhizium anisopliae (1144).

- O fungo M. anisopliae (1189) foi suscetível com os produtos Dipterex, Marshal e Stron.

- Nuvacron e Stron são compatíveis com B. bassiana (1196), Paecilomyces fumosoroseus (1200) e Sporothrix insectorum (1229).

- Marshal foi compatível com B. bassiana (1196) e S. insectorum (1229).

- Dipterex não afetou P. fumosoroseus (1200). 


\section{PRODUÇÃO DE FUNGOS ENTOMOPATOGÊNICOS PARA O CONTROLE DE Leptopharsa heveae}

\section{RESUMO}

Avaliou-se dois métodos de produção e dois meios de culturas para os fungos B. bassiana (1196), M. anisopliae (1189), Sporothrix insectorum (1229), Paecilomyces fumosoroseus (1200) e Verticillium lecanii (1200). O método de bandeja, consistiu na colocação do arroz pré-cozido, esterilizado e inoculado com o fungo em bandejas de plástico, com ciclo de produção de aproximadamente quinze dias. No outro método, foi usada uma caixa plástica, mantendo uma lâmina d'água no fundo do recipiente e um sistema de aeração constante para fornecer uma pressão positiva no sistema. Os meios líquidos testados foram a base de batata-dextrose-ágar (BDA) e meio de cultura completo (MC) utilizando frascos Erlenmeyer contendo $100 \mathrm{~mL}$ do meio, mantidos em agitação mecânica por um período de sete dias, a uma temperatura de $26 \pm 0,5^{\circ} \mathrm{C}$. Não houve diferença entre os meios líquidos. B. bassiana foi mais produtivo com $10^{9}$ conídios $/ \mathrm{mL}$, e os outros atingiram apenas $10^{7}$ conídios $/ \mathrm{mL}$. As espécies $P$. fumosoroseus e B. bassiana foram as que mais produziram pelo método da caixa e $B$. bassiana foi o fungo mais produtivo no método da bandeja. Entre os métodos de produção $V$. lecanii produziu mais no método de bandeja e $P$. fumosoroseus no método da caixa. 


\section{PRODUCTION OF ENTOMOPATHOGENIC FUNGI FOR THE CONTROL OF Leptopharsa heveae}

\section{SUMMARY}

Two production methods and two cultures media were evaluated for production the fungi Beauveria bassiana (1196), Metarhizium anisopliae (1189), Sporothrix insectorum (1229), Paecilomyces fumosoroseus (1200) and V. lecanii (1200). The tray method consisted of placing cooked, sterilized and inoculated rice into plastic trays for approximately fifteen days. The box method consisted of using a plastic box with a film of water on the bottom of the container and an aeration system to constantly supply a positive pressure to the system. The liquid media tested were a potato-dextrose-agar base (PDA) medium and a complete medium (MC). Erlenmeyer flasks containing $100 \mathrm{~mL}$ of the media, an agitated for seven days at $26 \pm 0.5^{\circ} \mathrm{C}$ were used in the experiments. There were no differences among the liquid media. B. bassiana was the most productive fungus with yield of $10^{9}$ conidia/mL, whereas the other fungi reached only $10^{7}$ conidia/mL. The species $P$. fumosoroseus and B. bassiana were the most productive using for the box method and B. bassiana was the most productive in the tray method. $V$. lecanii had better yield in the tray method and P. fumosoroseus in the box method.

\subsection{Introdução}

A capacidade dos fungos entomopatogênicos de se estabelecerem em determinado sistema após sua introdução vem sendo relatada por diversos autores. As introduções podem ser feitas utilizando insetos doentes ou por meio de aplicações do patógeno produzido em meios artificiais. 
Um dos maiores problemas da utilização de inseticidas biológicos é a competitividade com os produtos químicos disponíveis no mercado. Outro aspecto, relaciona-se com os fatores bióticos e abióticos que podem afetar a eficiência desses entomopatógenos no controle dos insetos

Alguns fungos entomopatogênicos como Hirsutella thompsonii e Zoophthora radicans podem ser produzidos em meios líquidos e sólidos, porém os conídios obtidos em meios sólidos não podem ser facilmente armazenados ou utilizados em formulações (McCabe \& Soper ${ }^{1}$, citado por Alves \& Pereira, 1998).

No Brasil e no exterior existem, atualmente, produções comerciais de algumas espécies de fungos entomopatogênicos, como por exemplo Beauveria bassiana, Verticillium lecanii e Metarhizium anisopliae. Esses patógenos podem ser utilizados para o controle de diferentes pragas em cultivos protegidos e campo (www.attra.org/attrapub/ipm.html).

No entanto, a maioria dos entomopatógenos, incluindo os fungos entomopatogênicos, não estão disponíveis em quantidades e formulações adequadas para serem utilizados no controle de pragas. Para serem utilizados com eficiência no controle microbiano de insetos, atuando como inseticidas biológicos na estratégia chamada introdução inundativa, esses patógenos necessitam estar disponíveis em grandes quantidades. Isso se deve ao fato que os insetos, normalmente, necessitam de um elevado potencial de inóculo para serem colonizados por estes patógenos (Alves, 1998a).

Cerca de 100 agentes de controle biológico são produzidos e comercializados para o controle de pragas de diversas culturas na Europa e juntamente com insetos polinizadores movimentaram cerca de U\$ 70 milhões em 1991 (Lenteren et al., 1997). No Brasil, segundo Faria \& Magalhães (2001) as quatro maiores empresas produziram algo em torno de 155 toneladas entre os fungos $B$. bassiana, $M$. anisopliae e $S$. insectorum, para controle de cigarrinhas, ácaros, brocas, cochonilhas e do percevejo-derenda.

\footnotetext{
${ }^{1}$ McCABE, D.; SOPER, R.S. Preparation of an entomopathogenic fungal insect control agent. United
} States Patent 4.530.834. 1985. 
A produção em escala industrial de fungos entomopatogênicos representa uma etapa crítica e limitante no desenvolvimento de um programa de controle microbiano para uma determinada praga. A pesquisa de novas metodologias de sistemas de produção é muito importante para tornar o controle microbiano de pragas economicamente viável para ser aplicado em grandes áreas.

O objetivo desse trabalho foi avaliar a produção de fungos entomopatogênicos para o controle de L. heveae, em meios líquidos, bem como a eficiência de sistemas diferenciados de produção em condições de laboratório.

\subsection{Material e Métodos}

\subsubsection{Produção em meios líquidos}

Foi avaliada a produção dos fungos Beauveria bassiana (1196), Metarhizium anisopliae (1189), Sporothrix insectorum (1229), Paecilomyces fumosoroseus (1200) e Verticillium lecanii (972) linhagens previamente selecionadas como promissoras para o controle microbiano de L. heveae na cultura da seringueira (Tanzini \& Alves, 2000). Esses fungos estão armazenados no Banco de Patógenos do Laboratório de Patologia e Controle Microbiano de Insetos em freezer $-40^{\circ} \mathrm{C}$, da ESALQ-USP.

A produção inicial de conídios foi realizada em placas de Petri contendo meio de cultura completo (MC) que consiste de: $0,36 \mathrm{~g} \mathrm{KH}_{2} \mathrm{PO}_{4} ; 1,05 \mathrm{~g} \mathrm{NaHPO} .7 \mathrm{H}_{2} \mathrm{O} ; 0,60 \mathrm{~g}$ $\mathrm{MgSO}_{4} .7 \mathrm{H}_{2} \mathrm{O} ; 1,00 \mathrm{~g} \mathrm{KCl} ; 10,00 \mathrm{~g}$ Glucose; 5,00g e Extrato de levedura em $1000 \mathrm{~mL}$ Água destilada. Os conídios foram inoculados nessas placas em câmara de fluxo laminar

que foram, posteriormente, incubadas em câmara climatizada $\left(26 \pm 0,5^{\circ} \mathrm{C}\right.$ e fotofase de 12 horas), durante um período de 10 dias para o crescimento e esporulação dos patógenos.

Após esse período os conídios foram raspados com o auxílio de uma espátula esterelizada e inoculados na concentração de $10^{3}$ conídios $/ \mathrm{mL}$ em frascos Erlenmeyer (500 mL), contendo $100 \mathrm{~mL}$ do meio MC e BDA (200 g Batata, 20 g Dextrose, 1,5g Ágar em $1000 \mathrm{~mL}$ de água) também esterilizado. Foram preparadas três repetições para cada meio de cultura testado. Os frascos foram mantidos em agitação mecânica com 220 
rotações por minuto, por um período de sete dias a uma temperatura controlada de $26 \pm 0,5^{\circ} \mathrm{C}$. Decorrido esse período foi retirado $1 \mathrm{~mL}$ do meio líquido de cada frasco e transferido para um tubo de vidro com $9 \mathrm{~mL}$ de água destilada estéril e realizadas diluições em série para obtenção de uma suspensão que permitiu a contagem dos conídios em câmara de Neubauer sob microscópio, sendo realizado duas vezes cada. Assim, avaliaram-se o número de conídios por mililitro dos diferentes tratamentos. Os resultados foram submetidos à análise de variância e as médias comparadas pelo teste de Tukey a 5\% de probabilidade.

Para avaliação da qualidade do inóculo estoque com relação a presença de contaminantes, duas amostras de $0,1 \mathrm{~mL}$ de cada Erlenmeyer foram transferidas para placas de Petri contendo meio de cultura BDA. As placas foram mantidas nas mesmas condições anteriores, por um período de sete dias. Os frascos que apresentaram contaminação foram descartados.

\subsubsection{Avaliação dos métodos de produção}

Para avaliação dos diferentes métodos de produção, foram utilizados os mesmos fungos e isolados do ensaio de meios líquidos.

O método da caixa consistiu de um recipiente de plástico com $20 \mathrm{~cm}$ de largura por $32 \mathrm{~cm}$ de comprimento e $25 \mathrm{~cm}$ de altura. Na tampa da caixa foram feitos dois orifícios de $0,7 \mathrm{~cm}$ de diâmetro para a saída do ar. Na lateral inferior do recipiente foi montado um sistema de aeração constante resultando em fluxo positivo, gerado por uma bomba de ar, tipo de aquário (marca Vigo-ar, Super II) e distribuído por meio de válvulas e mangueiras com uma pedra porosa na extremidade. $\mathrm{Na}$ saída de ar da bomba foi adaptado um filtro millipore $(0,2 \mu \mathrm{m})$, para garantir a ausência de contaminantes no processo de oxigenação. No fundo da caixa foi colocado 1 litro de água estéril com $2 \mathrm{~g}$ de antibiótico (streptomicina), formando uma lâmina d'água que, juntamente com o sistema de aeração por mangueiras, manteve o ambiente com umidade acima de $90 \%$ (Figura 23).

O substrato utilizado foi o arroz esterilizado em autoclave a $120^{\circ} \mathrm{C}$ por 20 minutos em sacos plásticos de polipropileno e posteriormente inoculados em câmara de 


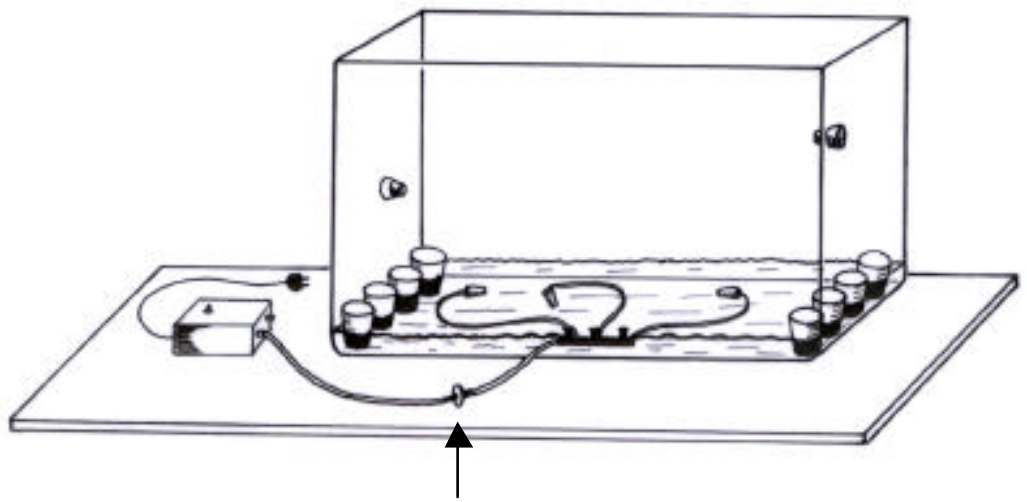

A

milipore

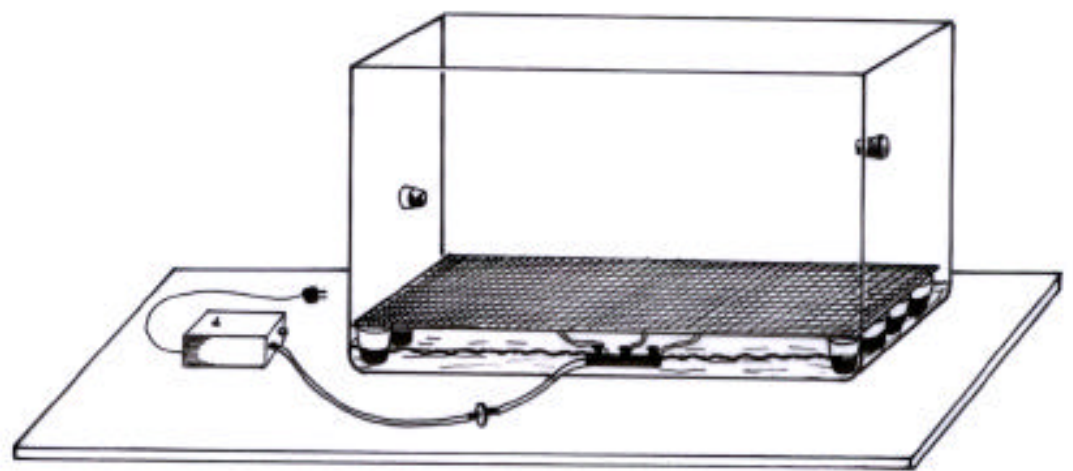

B

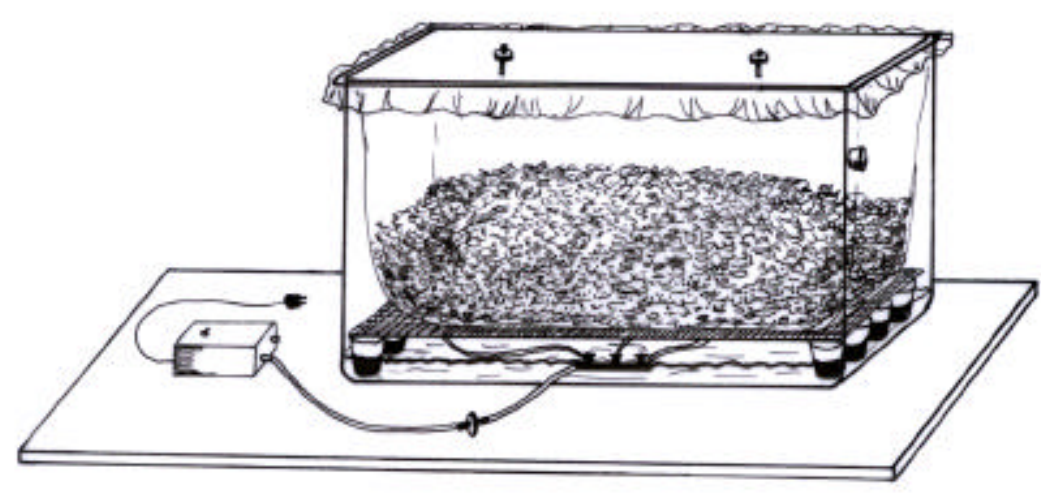

C

Figura 23- Caixa de produção de fungos entomopatogênicos. A- Vazia com sistema de aeração e água. B- Com tela para suporte do substrato. C- Com o substrato inoculado (Piracicaba-SP, 2001). 
fluxo laminar. Foram utilizados $10 \mathrm{~mL}$ do inóculo $\left(10^{3}\right.$ conídios $\left./ \mathrm{mL}\right)$ estoque para cada 400 gramas do substrato. Os sacos foram agitados manualmente para homogeneização do inóculo. O substrato de desenvolvimento do patógeno foi transferido para as caixas de produção (3 a $5 \mathrm{Kg}$ /caixa), permanecendo apoiado sobre um anteparo metálico a 2,5 $\mathrm{cm}$ de altura do fundo do recipiente. As caixas foram fechadas e mantidas em sala asséptica $\left(26 \pm 2{ }^{\circ} \mathrm{C}\right.$ e 12 horas de fotofase) durante cinco dias. A lâmina d'água presente no fundo da caixa foi retirada no terceiro dia após o início do experimento, através de um abertura situada no canto inferior do recipiente. A tampa da caixa de produção foi semi-aberta no quinto dia, visando favorecer a esporulação do patógeno e a secagem do substrato, permanecendo por mais cinco dias nessa condição (Figura 23).

O outro sistema de produção utilizado como comparação foi o de bandeja desenvolvido por Alves \& Pereira (1989). Esse método consiste, basicamente, na utilização de sacos plásticos, onde foram colocados cerca de 300 g de arroz pré-cozido e esterilizado em auto-clave. Após resfriado, o arroz foi inoculado com as matrizes selecionadas. Depois de 2 a 3 dias após a inoculação, foram selecionados os sacos de crescimento uniforme e sem contaminação e seu conteúdo foi adicionado em bandejas plásticas. Essas foram mantidas em sala asséptica, na temperatura de $27 \pm 1^{\circ} \mathrm{C}$ e 24 horas de fotofase, por 16 dias, para promover a esporulação do fungo. No sétimo dia, foi feito o cruzamento das bandejas para uma maior ventilação entre elas e secagem mais rápida do arroz com fungo (Figura 24).

Foram realizadas observações diárias avaliando-se visualmente a presença ou ausência de contaminantes.

No décimo dia após a inoculação foram retiradas da superfície do substrato, a uma profundidade de 1,5 cm, 10 amostras de 1 grama, escolhidas ao acaso para cada sistema de produção. As amostras foram colocadas em tubos de vidro contendo $10 \mathrm{~mL}$ de água destilada mais espalhante adesivo (Tween® 20). Os tubos foram agitados por 1 


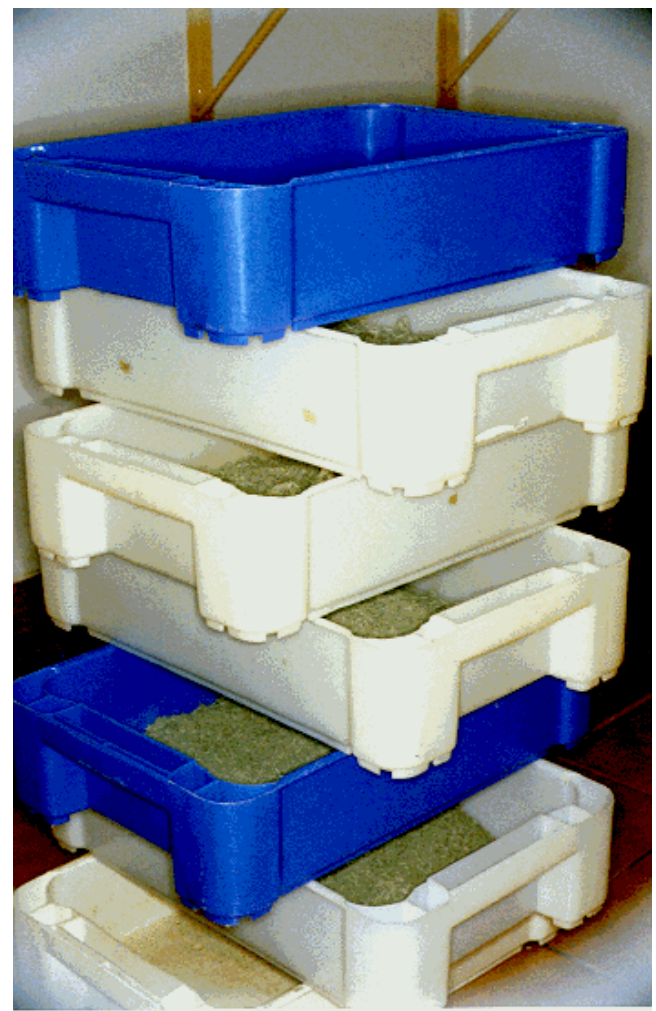

Figura 24- Produção de Metarhizium anisopliae pelo método de bandejas (PiracicabaSP, 2001).

minuto, e colocados em ultra-som por mais 10 minutos, para liberação dos conídios e homogeneização da suspensão. Em seguida, as amostras foram diluídas em série e quantificadas, duas vezes em câmara de Neubauer. Dessa forma, foi possível determinar o número de conídios produzidos por grama nos diferentes métodos de produção. Os resultados da avaliação dos diferentes substratos foram submetidos à análise de variância e as médias comparadas pelo teste de Tukey a $5 \%$ de probabilidade.

\subsection{Resultados e Discussão}

\subsubsection{Produção em meios líquidos}


$\mathrm{Na}$ avaliação de diferentes meios de cultura líquidos, o meio completo (MC) (cor clara) não diferiu do meio com batata-dextrose-ágar (BDA) (cor escura), para todos os hifomicetos testados, não mostrando exigências específicas entre os meios de cultura líquidos. B. bassiana foi o fungo que mais produziu chegando a $1 \times 10^{9}$ conídios $/ \mathrm{mL}$, enquanto que S. insectorum, P. fumosoroseus, M. anisopliae e V. lecanii produziram $10^{7}$ conídios/mL (Figura 25).

Apesar de existirem algumas dificuldades práticas para a produção de fungos em meios líquidos, esse método tem grandes vantagens no que se refere a facilidade de aplicação em condições de campo, pois o produto já se encontra pronto para ser colocado no pulverizador a ser utilizado, evitando-se com isso os gastos de mão-de-obra para a lavagem do material como é feito quando é produzido em meio sólido de arroz.

Segundo Alves \& Pereira (1998) a produção em meios líquidos utilizando fermentação contínua, pode ser empregada quando se deseja produzir grandes quantidades, como vem ocorrendo com B. bassiana, comercializado como Boverin, $V$. lecanii, comercializado na Europa e M. anisopliae, na formulação BIO 1020. A grande vantagem desse processo é a obtenção de elevadas quantidades de biomassa em um pequeno espaço físico e pouco tempo. As desvantagens estão na obtenção de meios de cultura adequados, na determinação das condições de desenvolvimento e na prevenção das contaminações secundárias.

No sistema de fermentação líquida, são poucos os fungos entomopatogênicos, como B. bassiana, que produzem propágulos infecciosos através desse método. Além disso, os conídios obtidos em meio líquido, usualmente, são menos virulentos e têm menos vitalidade do que os produzidos em superfície (Roberts \& Sweeney, 1982). Esse sistema de fermentação líquida é mais utilizado no método de produção bifásico, onde blastósporos e micélio são produzidos em meio líquido e então transferidos para a produção de esporos sobre superfície sólida (Roberts \& Yendol,1981). 




Figura 25- Produção de conídios em meios líquidos (Piracicaba-SP, 2001) 
A produção de B. bassiana, M. anisopliae, Nomuraea rileyi e $V$. lecanii foi estudada para controle de Rhyzopertha dominica, Sitophilus oryzae e Tribolium castaneum por Padin et al. (1996) utilizando meios líquidos a base de BDA e SDA (Sabouraud Yeats Agar). S. oryzae foi mais suscetível para B. bassiana, quando o fungo cresceu sobre BDA. T. castaneum e $R$. dominica tiveram a mesma suscetibilidade crescidos em ambos meios de cultura.

Outro método de produção de M. anisopliae foi estudado por Mello Pereira \& Ferreira da Eira (1999) que envolveu arroz em meio líquido, estrato de levedura, estrato de percevejo-da-soja (Nezara viridula) sob seis concentrações e o meio comercial sólido em arroz. Foi observado que açúcar na menor concentração e o estrato de $N$. viridula produziu duas vezes mais conídios/g quando comparado com a maior concentração e 51 vezes mais barato do que o processo de produção convencional. A viabilidade e patogenicidade não diferiram entre os métodos de cultivo.

Em cinco diferentes meios líquidos para produção de $P$. fumosoroseus Vidal et al. (1998a), observaram a produção de blastósporos em três meios e conidiósporos nos outros dois meios testados.

Estudos futuros devem ser direcionados nesse sentido, pois a praticidade que o método de produção líquida apresenta em aplicações em condições de campo é muito vantajosa para o controle microbiano de insetos.

\subsubsection{Comparação entre sistemas de produção}

A produção de fungos entomopatogênicos pelo método de bandejas descrito por Alves \& Pereira (1989) consiste, basicamente, na inoculação do substrato em sacos de polipropileno e incubação do material. Na etapa de incubação, período de três a quatro dias em que ocorre o crescimento micelial do patógeno, os sacos são mantidos em câmaras climatizadas antes da transferência para as bandejas plásticas de produção. Todo o processo de produção em bandejas ocorre em um período médio de quinze dias.

O sistema de produção em caixa elimina a etapa de incubação do patógeno em câmara climatizada. A injeção de ar forçado substitui essa etapa, fornecendo a umidade necessária para o bom crescimento vegetativo do fungo e auxiliando a secagem após a 
esporulação. Deste forma, observou-se uma redução no tempo total de produção em aproximadamente cinco dias em comparação ao método de bandeja.

Pode-se observar que entre os fungos testados (letra maiúscula) no método de caixa, $P$. fumosoroseus foi o que mais produziu, chegando a ser $15 \%$ mais produtivo do que B. bassiana que foi o segundo em produção. A umidade extra fornecida nas caixas plásticas proporcionou um acréscimo de produção para essa espécie de fungo. A umidade é um fator abiótico de extrema importância no processo de doença sobre insetos e também na produção in vitro, principalmente durante a conidiogênese (Doberski, 1981; Ramoska, 1984). A produção intermediária foi de $S$. insectorum. Os fungos $M$. anisopliae e V. lecanii foram os que menos produziram nesse método (Figura 26).

O fungo $M$. anisopliae foi cultivado em substrato sólido com e sem aeração forçada usando uma mistura de quirera e arroz em casca por Dorta et al. (1996). Depois de 90 a 100 h o crescimento estacionou e a produção foi de $2,3 \times 10^{10}$ esporos/g de arroz. Este método produziu $80 \%$ a mais do que o valor obtido pelo método padrão.

$\mathrm{Na}$ produção em bandejas, B. bassiana foi o fungo mais produtivo, sendo intermediários $V$. lecanii e $S$. insectorum e menos produtivos $P$. fumosoroseus e $M$. anisopliae. Provavelmente, por ser um método menos úmido não houve favorecimento de $P$. fumosoroseus. Já $M$. anisopliae, B. bassiana e $S$. insectorum tiveram produções semelhantes em ambos os métodos. B. bassiana produziu $35 \%$ a mais que $S$. insectorum.

Entre os métodos testados (letras minúsculas) (Figura 26), V. lecanii produziu 68\% a mais no método de bandeja em relação ao da caixa. P. fumosoroseus produziu $70 \%$ a mais no método da caixa em relação ao de bandeja, o que mostra que a umidade foi um fator determinante para a produção desse fungo. A metodologia de produção não teve influência na produtividade de $M$. anisopliae, B. bassiana e $S$. insectorum.

O pequeno índice de contaminação observado no método de caixa foi, na maioria das vezes, de forma localizada, semelhante ao que ocorre no método de bandeja. Esses pequenos focos de contaminação são oriundos de gotas de água da condensação e crescem de maneira restrita sobre o substrato já colonizado, não afetando a produção. Em casos isolados foi observado uma contaminação generalizada do substrato por Rhizopus e Fusarium, sendo necessária a eliminação do material e a repetição do experimento. Nesses 


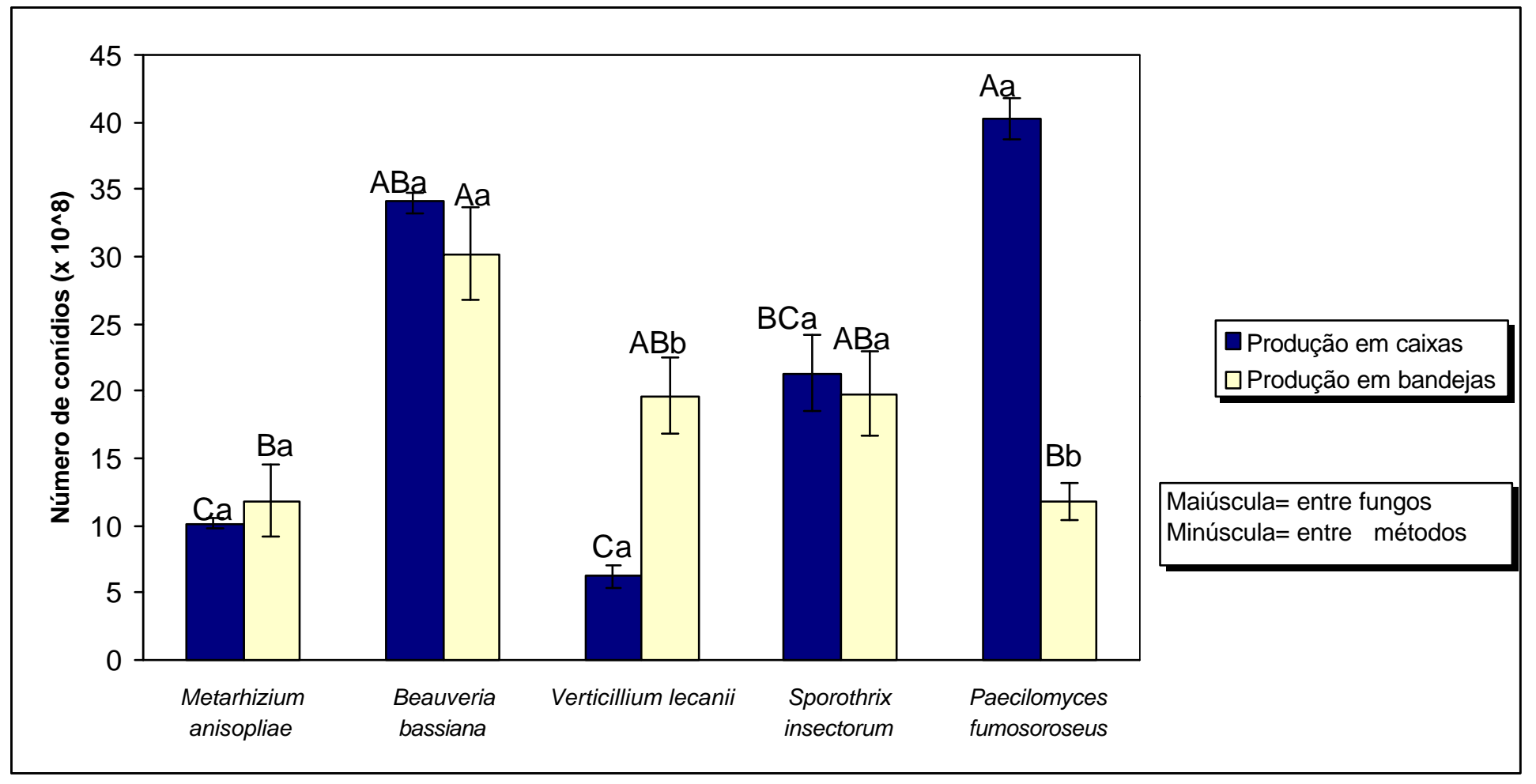

Figura 26- Produção de conídios de fungos entomopatogênicos obtidos nos diferentes processos (Piracicaba-SP, 2002). 
casos também foi detectada a presença de bactérias do gênero Bacillus nas camadas inferiores, que foram favorecidas pelas condições de deterioração do substrato.

Do volume de água adicionado na caixa (1 litro) foi retirado em média 600 a 700 $\mathrm{mL}$. A diferença do volume inicial e final foi correspondente a água evaporada no processo e utilizada pelo patógeno no seu desenvolvimento. A utilização de antibiótico na lâmina d'água favorece para a redução da contaminação.

Buscando meios alternativos de produção massal Vilas Boas et al., (1996) usaram sementes de Phaseolus vulgaris, P. lunatus e sorgo cozidos e esterilizados. Cada meio recebeu $10 \mathrm{~mL}$ de uma suspensão de $M$. anisopliae e B. bassiana numa concentração de $10^{7}$ conídios/mL. A maior concentração obtida de $M$. anisopliae foi do substrato com $P$. lunatus e a melhor de B. bassiana foi com arroz. Quanto a viabilidade e patogenicidade, ambos os fungos não apresentaram diferenças quando cultivados nos diferentes meios.

Lopez et al. (1999) testaram seis substratos de folhas de palmeiras, sementes e mesocarpo para produzir V. lecanii, $P$. farinosus, $M$. anisopliae, B. bassiana, Trichoderma harzianum e Gliocladium virens. Os fungos micoparasitas, em geral, colonizaram mais rápido e melhor os substratos das plantas do que os entomopatógenos.

Para a produção de $V$. lecanii, foi testado o mesocarpo de amêndoa por Lopez \& Carbonell (1998) e chegaram a conclusão que pode ser mais uma alternativa de substrato para a produção desse fungo, apesar de ter sido encontrado contaminação de diversos fungos saprófitas.

Estudando meios alternativos para produção de $P$. farinosus, Gopalakrishnan et al., (1999), concluíram que em $100 \mathrm{~g}$ de sorgo produziu em média $10 \times 10^{12}$ esporos, sendo que Sabouraud Maltose Agar + Levedura produziu 11x10 ${ }^{12}$ esporos/100 mL de meio.

Estudos biológicos e físicos sobre oito isolados de $V$. lecanii foram realizados por Lopez \& Carbonell (1999) os quais concluíram que a melhor temperatura para o desenvolvimento desse fungo foi de $25^{\circ} \mathrm{C}$ e $\mathrm{pH}$ 7. Também estudando o efeito de temperatura sobre germinação, crescimento e produção de 32 isolados de M. anisopliae, Cross \& Bidocka (1999) observaram que todos os isolados desenvolveram-se melhor com a maior temperatura testada que foi de $22^{\circ} \mathrm{C}$. Somente dez isolados tiveram habilidade de se desenvolver em temperatura de $8^{\circ} \mathrm{C}$, o que era uma característica importante e desejável para o controle biológico no Canadá. 
Estudando mais detalhadamente o efeito do pH, St. Leger et al. (1999), afirmaram que o $\mathrm{pH}$ do ambiente regula a virulência de $M$. anisopliae. Também foi avaliado o efeito de isotiocinatos sobre o crescimento de $M$. anisopliae por Inyang et al., (1999) e concluíram que esse composto inibiu a germinação, crescimento e afetou a habilidade de infectar insetos.

Em estudos futuros poderiam ser testadas fontes de nitrogênio como combinação entre esses métodos, para obtenção de um melhor rendimento. Nahas \& Arai (1987) testaram diferentes meios e chegaram a conclusão que a peptona foi uma boa fonte de nitrogênio. Também Samsináková et al. (1981) selecionaram esse produto na concentração de $0,8 \%$ e produziu $3,8 \times 10^{11}$ esporos de $B$. bassiana por $25 \mathrm{~cm}^{2}$. Contudo, esses compostos bem como de antibióticos que potencializem a produção possuem um custo elevado, devendo ser considerados em escala comercial.

\subsection{Conclusões}

- Não existe diferença entre os meios líquidos a base de BDA e MC para produção de Beauveria bassiana, Metarhizium anisopliae, Paecilomyces fumosoroseus, Sporothrix insectorum e Verticillium lecanii.

- O fungo B. bassiana produz $10^{9}$ conídios/mL nos meios líquidos BDA e MC, enquanto que $M$. anisopliae, S. insectorum, P. fumosoroseus e $V$. lecanii produzem $10^{7}$ conídios/mL.

- O método da caixa foi mais produtivo para os fungos $P$. fumosoroseus e $B$. bassiana.

- No método da bandeja, B. bassiana foi o mais produtivo. 


\title{
8 CICLO BIOLÓGICO DE FUNGOS ENTOMOPATOGÊNICOS SOBRE
}

\author{
Leptopharsa heveae
}

\section{RESUMO}

Os fungos M. anisopliae, B. bassiana. V. lecanii, S. insectorum e P. fumosoroseus foram aplicados em ninfas de $4^{\circ}$ ínstar de $L$. heveae para observação dos ciclos das relações patógeno-hospedeiro. A aplicação foi feita com uma suspensão de $1 \times 10^{8}$ conídios $/ \mathrm{mL}$ através de torre de Potter a uma pressão de 15 libras/pol'. Para as observações em Microscópio Eletrônico de Varredura LEO 435VP (MEV) as placas foram após 0, 24, 48, 72 e $96 \mathrm{~h}$ da inoculação e imediatamente transferidas para freezer, para morte do inseto e paralização do desenvolvimento do entomopatógeno. Os insetos foram fixados em "stubs" mantidos em um recipiente fechado por $48 \mathrm{~h}$, com Tetróxido de Ósmio $\left(\mathrm{OsO}_{4}\right)$ a $2 \%$. Após a fixação, o material foi mantido em dessecador de vidro com sílica-gel por mais $48 \mathrm{~h}$. Ao final, foi metalizado com banho de ouro por 180 segundos, no evaporador Balzers MED010 e submetido as observações sob uma voltagem de $20 \mathrm{kV}$ no MEV. Em geral, todos os hifomicetos apresentaram ciclo biológico semelhante sobre $L$. heveae, tendo um período de adesão, germinação e início da penetração de 24 h, crescimento vegetativo entre 48 e 72 h, ocorrendo nesse período a morte do inseto e a extrusão dos patógenos e depois de $96 \mathrm{~h}$ a conidiogênese dos fungos. 


\section{BIOLOGICAL CYCLE OF ENTOMOPATHOGENIC FUNGI}

ON Leptopharsa heveae

\section{SUMMARY}

The fungi Metarhizium anisopliae, Beauveria bassiana. Verticillium lecanii, Sporotrix insectorum and Paecilomyces fumosoroseus were applied to 4th instar nymphs of L. heveae for observation of the pathogen-host cycles. Suspensions containing $1 \times 10^{8}$ conidia/mL were applied through Potter tower using pressure of 15 libras/pol ${ }^{2}$. For the observations in Scanning Electronic Microscope LEO 435VP (SEM), plates with inoculated nymphs were removed after incubation for $0,24,48,72$ and $96 \mathrm{~h}$ and immediately transferred to freezer to kill the insects and stop of the development of the entomopathogens. The insects were fixed on "stubs" with $2 \%$ Osmium Tetroxid $\left(\mathrm{OsO}_{4}\right)$ for $48 \mathrm{~h}$. After the fixation, the material was maintained in glass desiccator with silica-gel for additional $48 \mathrm{~h}$. Specimes were coated with gold for 180 seconds in the evaporator Balzers MED010 and observed at $20 \mathrm{kV}$ in SEM. In general, all the hyphomycetes had similar biological cycle on L. heveae. Adhesion, germination and beginning of the penetration occurred within $24 \mathrm{~h}$. Vegetative growth occurred between 48 and $72 \mathrm{~h}$, when the insect died and the extrusion of the pathogens through the cuticle occurred. After $96 \mathrm{~h}$, conidiogenesis occurred for all fungi.

\subsection{Introdução}

Os aspectos relacionados com o ciclo dos fungos entomopatogênicos no percevejo-de-renda-da-seringueira são poucos conhecidos. A importância desses estudos para o conhecimento das relações patógeno-hospedeiro e das fases do ciclo da doença é de fundamental importância para o desenvolvimento de uma estratégia eficiente de controle.

Estudos semelhantes já foram conduzidos por diversos autores e com diversos insetos como de Neves et al. (1998) para o conhecimento do ciclo de B. bassiana e M. 
anisopliae em Cornitermes cumulans (Isoptera: Termitidae) e a capacidade de limpeza dos cupins, além da comparação de métodos de fixação para observação desses insetos utilizando o Microscópio Eletrônico de Varredura (MEV). Moino Jr. \& Alves (1998) fizeram estudos semelhantes utilizando os mesmos fungos com Heterotermes tenuis.

Utilizando vários métodos, entre eles o MEV, Boucias \& Pendland (1982) estudaram os estágios de desenvolvimento de Nomuraea rileyi sobre lagarta Anticarsia gemmatalis. Foi avaliado também o crescimento de B. bassiana sobre o tegumento do gafanhoto migrador Melanoplus sanguinipes por Bidochka \& Khachatourians (1992) utilizando essa metodologia. O modo de infecção de Frankliniella occidentalis por $M$. anisopliae foi também demonstrado com essa técnica por Vestergaard et al. (1999).

Sobre o pulgão da batata Macrosiphum euphorbiae, Askary et al. (1999), além do MEV, utilizaram também a microscopia eletrônica de transmissão e microscopia de luz para estudos de contaminação por $V$. lecanii. Utilizando também vários métodos, entre eles o MEV, Jeffs et al. (1999) estudaram a superfície de 24 isolados de fungos entomopatogênicos quanto a sua rugosidade, composição química, física e dimensões.

O objetivo desse trabalho foi de avaliar a duração das diferentes fases do ciclo biológico dos fungos entomopatogênicos selecionados para controle de L. heveae.

\subsection{Material e Métodos}

O experimento foi realizado no Setor de Entomologia da ESALQ/USP, Laboratório de Patologia e Controle Microbiano de Insetos e as observações e elétromicrografias realizadas no Núcleo de Apoio à Pesquisa/Microscopia Eletrônica Aplicada à Pesquisa Agropecuária (NAP/MEPA) da ESALQ/USP.

Os insetos foram obtidos do seringal do campus e mantidos em placas de plástico transparente de $6 \times 1,5 \mathrm{~cm}$ (Corning), com um disco de folha de seringueira de $5 \mathrm{~cm}$ de diâmetro sobre $10 \mathrm{~mL}$ de ágar-água a $2 \%$ e a borda da folha recoberta.

Os isolados testados foram os previamente selecionados para controle de $L$. heveae, sendo os seguinte: M. anisopliae (1189), B. bassiana (1196), V. lecanii (972), S. insectorum (1229) e P. fumosoroseus (1200). 
A produção de conídios dos patógenos, foi efetuada em placas de Petri com meio de cultura BDA (200g de batata, 20g dextrose, 15g ágar e 1000mL de água), em câmara climatizada a $26 \pm 0,5^{\circ} \mathrm{C}$ e fotofase de 12 horas. Após dez dias de incubação os conídios foram colhidos com uma espátula de borracha para a preparação do inóculo. Em seguida foram preparadas suspensões de conídios dos isolados com água destilada mais espalhante adesivo (Tween $40^{\circledR}$ ) a $0,1 \%$.

A aplicação da suspensão de $1 \times 10^{8}$ conídios/mL foi feita sobre a superfície adaxial dos discos de folhas e percevejos-de-renda-da-seringueira através do uso da torre de pulverização de Potter (Burkard Manufacturing, Rickmansworth, Herts, Reino Unido) calibrada a uma pressão de 15 libras/pol ${ }^{2}$. Foi utilizado um volume de $2 \mathrm{~mL}$ de suspensão $10^{8}$ conídios $/ \mathrm{mL}$ em cada pulverização, o equivalente a $0,2 \mu \mathrm{L} / \mathrm{cm}^{2}$.

O número de insetos utilizados por repetição foi de dez ninfas do $4^{\circ}$ ínstar/placa, perfazendo um total de 50 insetos por tratamento.

Após a inoculação, as placas foram tampadas e mantidas em câmara climatizada, tipo B.O.D., regulada à temperatura de $27 \pm 1{ }^{\circ} \mathrm{C}$, umidade relativa de $70 \pm 10 \%$ e fotofase de 12 horas.

Para as observações em Microscópio de Varredura (MEV), as placas foram retiradas da B.O.D. após 0; 24; 48; 72; 96h da inoculação e imediatamente transferidas para freezer $40^{\circ} \mathrm{C}$ para morte do inseto e paralização do desenvolvimento do entomopatógeno. Em seguida, o inseto foi retirado e colocado sobre uma fita de carbono colada em um "stub" (aparato para observação de espécimes em MEV). Esse material contendo os insetos foi

acondicionado em um recipiente fechado contendo Tetróxido de Ósmio $\left(\mathrm{OsO}_{4}\right)$ a $2 \%$ e mantido envolto por papel alumínio, dentro da capela por um período de $48 \mathrm{~h}$, até a volatilização do produto.

Após a fixação, o material foi mantido em dessecador de vidro com sílica-gel para a dessecação por mais $48 \mathrm{~h}$, onde foi mantido em baixa umidade relativa. Ao final, o material foi metalizado recebendo banho de ouro, durante 180 segundos, no evaporador Balzers, MED010 e submetido as observações ao Microscópio Eletrônico de Varredura modelo LEO $435 \mathrm{VP}$ sob uma voltagem de $20 \mathrm{kV}$. 


\subsection{Resultados e Discussão}

$\mathrm{O}$ adulto do percevejo-de-renda-da-seringueira ( $L$. heveae) apresenta um comprimento de 3,50 a 4,20mm e largura de 1,35 a 1,50mm, cor esbranquiçada, pronoto reticulado, tricarenado, élitros estendendo posteriormente ao abdome (Prancha I). A cabeça é coberta com uma exudação branca, com cinco espinhos testáceos (Prancha II-a e II-e). O tarso e olho composto estão apresentados na Prancha (I-b e I-d) (Drake \& Poor, 1935).

As antenas apresentam numerosos "espinhos tuberculosos" (Prancha II-c). Os tingídeos normalmente apresentam essas estruturas tanto em ninfas como em adultos. Em espécies de Stephanitis foi notado compostos de cromanonas e diquetonas nessas estruturas (Oliver et al., 1985).

Os conídios de M. anisopliae (Prancha III-a) aderidos ao corpo de L. heveae logo após aplicação, apresentaram expansões laterais para penetração no tegumento, com características de um apressório ou tubo germinativo, que estão associadas ao processo de penetração na cutícula do inseto. Pode-se observar também a presença de um halo ao redor dos conídios, provavelmente pela liberação de exoenzimas produzidas pelo patógeno. Segundo Boucias \& Pendland (1982), as ceras cuticulares servem como um químicoestimulante para a formação do tubo germinativo. St. Leger et al. (1987) afirmaram que os conídios possuem altos níveis de aminopeptidases, que podem criar condições favoráveis para a atuação das enzimas extracelulares.

A fixação de conídios na cutícula, formação do tubo germinativo e apressório de M. anisopliae, foram observados no MEV por Bittencourt et al. (1999) sobre Boophilus microplus.

Com 24 h após aplicação, Prancha III-b, foi observada a germinação dos conídios sobre o tegumento do inseto. Após 48 h, Prancha III-c, foi possível observar o crescimento vegetativo. A mortalidade de ninfas do percevejo-de-renda-da-seringueira chegou a $81 \%$ nesse período, o que é uma característica bastante desejável desse patógeno para um controle microbiano dessa praga.

Com 72 e 96h (Pranchas III-d e IV-a,b) as mortalidades foram de 92 e 100\%, respectivamente. Deu-se início a extrusão do patógeno e a conidiogênese, principalmente nas regiões intersegmentais dos insetos, e uma grande quantidade nos olhos compostos. Os 
conídios se formaram sobre ramificações compostas de um conjunto de micélio, chegando a formar uma massa sobre o inseto.

Todas as fases do ciclo das relações patógeno-hospedeiro, principalmente a germinação, penetração e reprodução variam em função de condições do ambiente, principalmente no que se refere a temperatura e umidade do hospedeiro. Sendo que a temperatura é importante em todo o desenvolvimento do patógeno, desde a germinação à conidiogênese. A umidade relativa influencia as etapas que ocorrem no exterior do hospedeiro como a germinação e penetração, e principalmente a conidiogênese. Ainda a quantidade de conídios depositados sobre os indivíduos, pode ser mais um fator e de menor controle (Alves,1998b; Neves 1998).

Na Prancha V-a,b,c,d, pode-se observar os conídios aderidos de P. fumosoroseus e germinandos em regiões do olho, antena e tarso 24 h após a aplicação. Os conídios desse patógeno são alongados, menores ou iguais a $3 \mu$ e os conidióforos são simples (Prancha VIa) ou verticiliados (Prancha VI-c). Já com 72 h, ninfa e adulto apresentavam-se todo miceliado (Prancha V-e e VI-b) e com mortalidade superior a 90\%, chegando a $100 \%$ com 96 h. Fargues et al. (1994) relataram que os conídios de P. fumosoroseus germinados e corpos hifais foram mais agressivos para lagartas de $1^{\circ}$ instar de Spodoptera frugiperda do que conídios não-germinados. Os autores sugerem que o uso desses propágulos pode ser uma vantagem no controle biológico.

Com 24 h após a aplicação sobre ninfas de L. heveae, os conídios de S. insectorum germinaram, ocorrendo também o desenvolvimento do micélio sobre a superfície do inseto e a formação de hifas septadas (Prancha VII-a,b,c). Com 48 h, esse fungo causou $24 \%$ de mortalidade dos insetos e com 72 e 96 h, 53 e 85\%, respectivamente (Prancha VIII-a,b,c). Com 96 h ocorreu o acme da conidiogênese tomando todo o corpo do inseto e fixando-o na folha de seringueira, uma característica observada quando ocorre epizootia. Empiricamente esse fungo têm sido utilizado em aproximadamente 30.000 ha de cultivo de seringueira, sem se conhecer seu processo infectivo sobre o inseto.

Os conídios de B. bassiana foram observados aderidos em todo o corpo do inseto, principalmente no tarso e nas regiões próximas as setas da superfície adaxial do inseto (Prancha IX-a,b,c). Esses apresentam forma ovóides e cilíndricos. Jeffs et al. (1999) estudaram três tipos de esporos de $B$. bassiana quanto a sua composição química e 
estrutural. Segundo Alves (1998b), esse gênero de fungo ocorre em mais de 200 espécies de insetos e ácaros, sendo de ocorrência generalizada em diversos países, podendo ser mais uma opção de controle de L. heveae.

A germinação foi observada $48 \mathrm{~h}$ após a aplicação e com $96 \mathrm{~h}$ o inseto apresentava-se totalmente colonizado (Prancha X-a,b). A duração das diferentes fases do ciclo das relações patógeno-hospedeiro depende das condições da doença. A umidade relativa favorável é de aproximadamente $90 \%$ e a temperatura na faixa de 23 a $28^{\circ} \mathrm{C}$. Com 96 h ocorreu a formação de grande quantidade de conidióforos e ramificações na forma de ziguezague, característica desse fungo (Prancha X-c). A patogenicidade desse fungo foi menor em relação aos outros agentes estudados, sendo que com 3 d.a.a. a porcentagem de mortalidade foi de apenas $30 \%$ e somente com $96 \mathrm{~h}$ atingiu a $94 \%$ de mortalidade.

Com V. lecanii, o tempo do ciclo patógeno-hospedeiro foi semelhante aos demais fungos estudados, tendo a germinação dos conídios ocorrido 24 h após (Prancha XI-a,b). Em afídeos, Askary et al. (1999) observaram que após 24 h da inoculação os micélios com hifas colonizaram a superfície cuticular do pulgão e penetraram através das setas. Segundo Viègas $^{2}$ citado por Alves (1988b), esses conídios são envolvidos por uma substância transparente, mucilaginosa e viscosa, que além de proteger contra a dessecação, facilita a adesão desses conídios à superfície do hospedeiro.

Foi possível observar a formação do conidióforo com 48 h (Prancha XI-c). Decorridos $72 \mathrm{~h}$, notou-se pela primeira vez a presença de cristais tóxicos formando sob o tegumento do inseto (Prancha XI-d,e) já descritos, em Beauveria spp. Esses cristais, provavelmente, são formados por ácido oxálico que é tóxico para organismos vivos em geral. Pela elétromicrografia da Prancha XI-e, aparentemente a formação se dá pela extrusão do micélio. Também foi observado a presença de cristais, na cavidade geral de ácaros tetraniquídeos infectados por Beauveria spp. (M.A. Tamai \& S.B. Alves, dados não publicados). Em ácaros oribatídeos, Norton \& Behan-Pelletier (1991) observaram a presença de carbonato de cálcio que foi liberado por ácaros da família Ptyctima, e em três espécies de Enarthronota foi encontrado oxalato de cálcio.

Com 96 h após a inoculação, externamente, o corpo do inseto apresentou-se totalmente recoberto pelo patógeno. Askary et al. (1999) afirmaram que após esse período as hifas invadiram totalmente a hemocele e proliferaram em grande quantidade de órgãos e 
tecidos, como na hemolinfa, corpos gordurosos, aparelho digestivo e reprodutor. Com microscopia eletrônica de transmissão, esses autores mostraram que com $120 \mathrm{~h}$ todos os tecidos de Macrosiphum euphorbiae estavam totalmente tomados por V. lecanii.

Em geral, todos esses hifomicetos estudados sobre L. heveae apresentaram um ciclo de relação fungo-hospedeiro semelhantes. Com um período de adesão, germinação e início da penetração de $24 \mathrm{~h}$, isso pode ser uma das vantagens dos fungos em relação a outros patógenos que necessitam ser ingeridos por via oral. Segundo Alves (1998b), os conídios e esporos dos fungos possuem alta capacidade de disseminação, podendo ser levados pelos diferentes agentes de disseminação para muitos locais distantes. Além de poderem infectar diferentes estágios de desenvolvimento, como ovos, larvas, pupas e adultos.

Os mecanismos de adesão não são totalmente conhecidos. Segundo Boucias et al. (1988) existem forças eletrostáticas que atuam nesse processo. Também a adesão do conídio podem estar relacionados com o tegumento do inseto que apresenta natureza lipoprotéica.

A germinação de conídios se caracteriza pela formação de um tubo germinativo e depende de condições como temperaturas de 23 a $30^{\circ} \mathrm{C}$ e umidade relativa acima de $90 \%$. Outro fator que influi, são as condições de armazenagem desses fungos, Alves et al. (1995) estudaram conídios de B. bassiana armazenados em geladeira por sete anos. Esses conídios necessitaram de 72 a 96 horas para germinar sob temperatura de $26^{\circ} \mathrm{C}$, enquanto conídios não armazenados ou armazenados em freezer germinaram entre 18 e 24 horas. Os conídios armazenados em geladeira, apesar de apresentarem 100\% de viabilidade, só conseguiram matar $20 \%$ de larvas de Diatraea saccharalis, enquanto os não armazenados ou armazenados em freezer causaram 100\% de mortalidade.

A colonização ocorreu entre 48 e 72 h e nesse período a maior parte dos insetos morreram. Normalmente não ocorre a desintegração dos tecidos por microrganismos saprófitas que vivem dentro e sobre o inseto, porque o patógeno secreta substâncias

\footnotetext{
${ }^{2}$ Viègas, A.P. Empusa dysdercy n.sp., um novo parasita de Dysdercus. Jornal de Agronomia n.2, p.229-258. 1939.
} 
antibióticas, como a oosporina, responsável pela coloração rosa dos cadáveres como quando contaminados com B. bassiana (Figura 27).

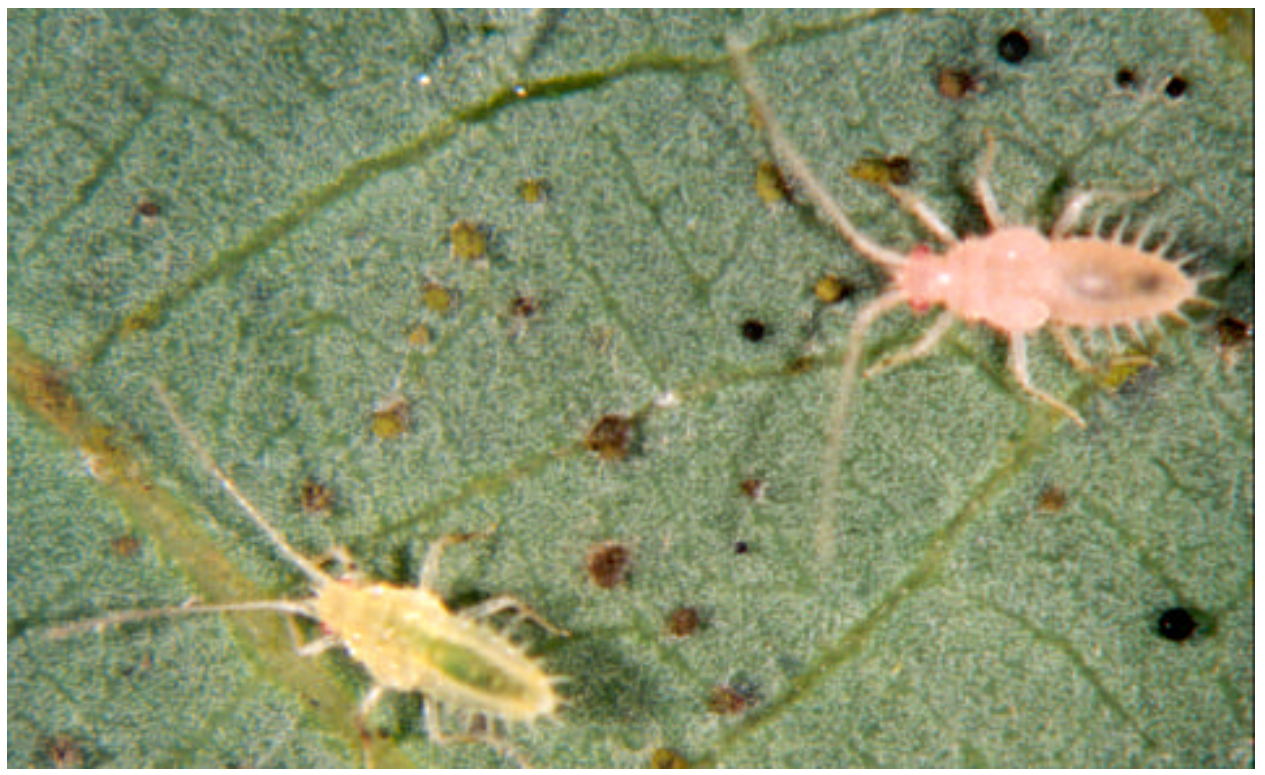

Figura 27- Ninfas de Leptopharsa heveae 72 h após aplicação de B. bassiana (no canto direito uma ninfa com sintoma de oosporina.) (Piracicaba-SP, 2001).

Após a morte do inseto, o micélio toma toda a superfície do corpo, iniciando pelas regiões intersegmentais, ocorrendo em seguida a esporulação do fungo com 96h após a inoculação (Figura 28). A morte, segundo Alves (1998b) ocorre devido a produção de micotoxinas, mudanças patológicas na hemocele, ação histológica, bloqueio mecânico do aparelho digestivo devido ao crescimento vegetativo e outros danos físicos, em decorrência do crescimento do micélio e do início do processo de esporulação do fungo.

Entre os mecanismos de defesa do inseto pode-se notar que o tegumento é uma barreira mecânica que atua constantemente, pois a troca de exúvia logo após a adesão do conídio permite com que o inseto escape da ação do patógeno. Outros fatores citados por Omoto \& Alves (1998) são as ações dos hemócitos (defesa celular) e de mecanismos bioquímico-fisiológicos, imunológico e corportamental. 


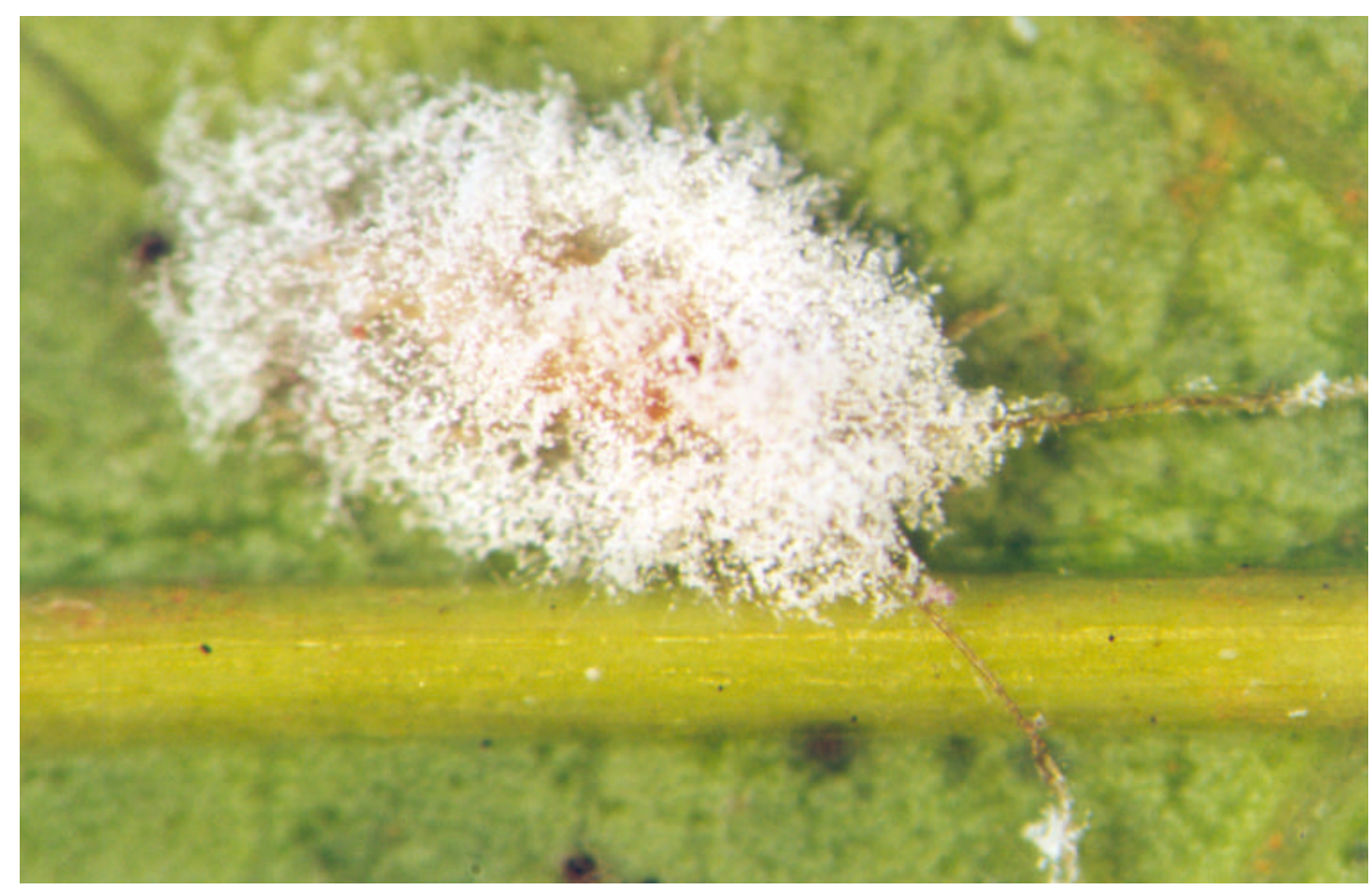

Figura 28- Ninfa de Leptopharsa heveae no acme da conidiogênese de Beauveria bassiana. (Piracicaba-SP, 2001)

\subsection{Conclusões}

- Os fungos Metarhizium anisopliae, Beauveria bassiana, Verticillium lecanii, Sporothrix insectorum e Paecilomyces fumosoroseus apresentam um ciclo biológico semelhante sobre Leptopharsa heveae.

- A adesão, germinação e início da penetração desses fungos, ocorre em 24 h após a aplicação sobre ninfas do $4^{\circ}$ ínstar do percevejo-de-renda-da-seringueira.

- O crescimento vegetativo dos fungos estudados sobre essa praga ocorre de 48 a $72 \mathrm{~h}$.

- Após 96 h da aplicação dos patógenos sobre L. heveae ocorre a conidiogênese. 


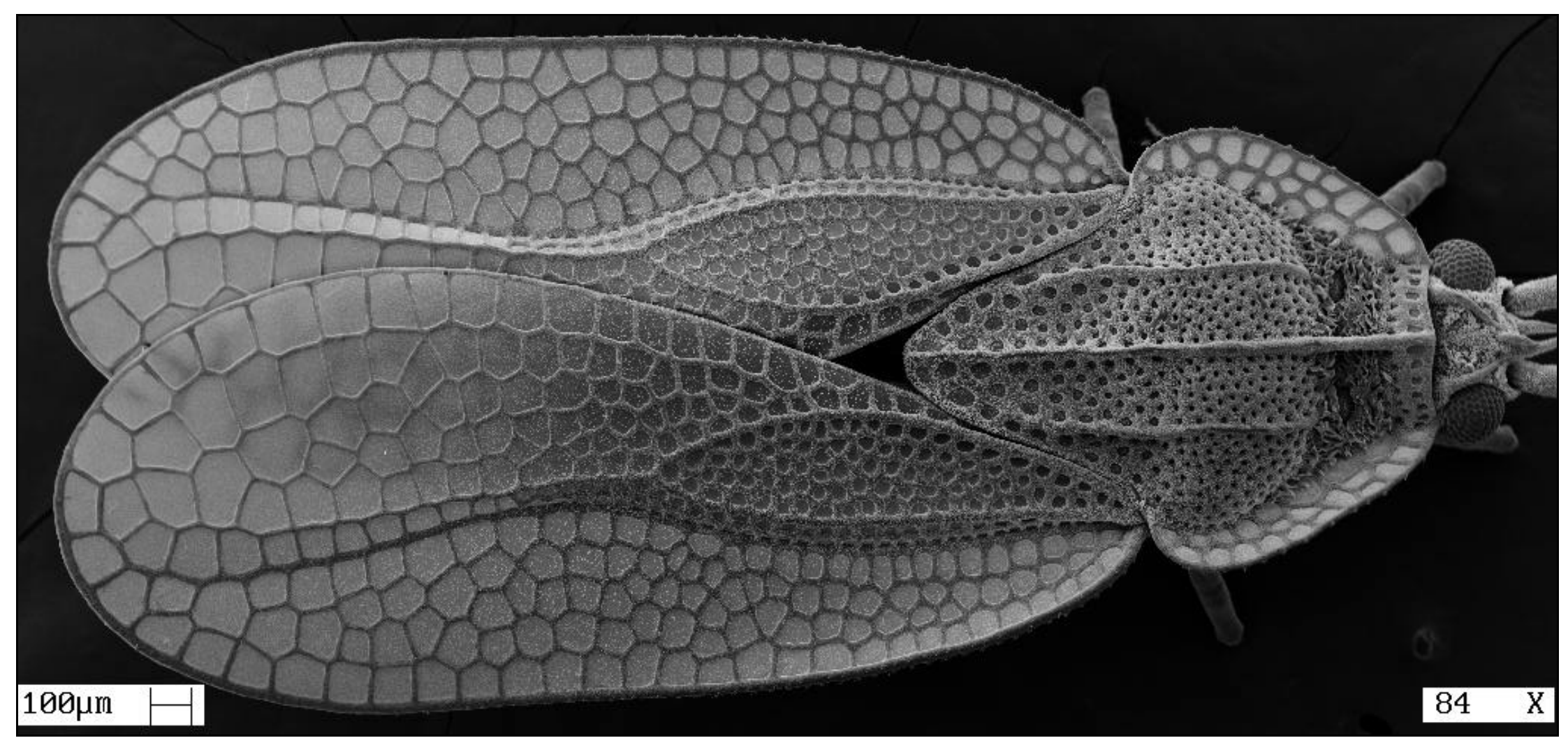

Prancha I 

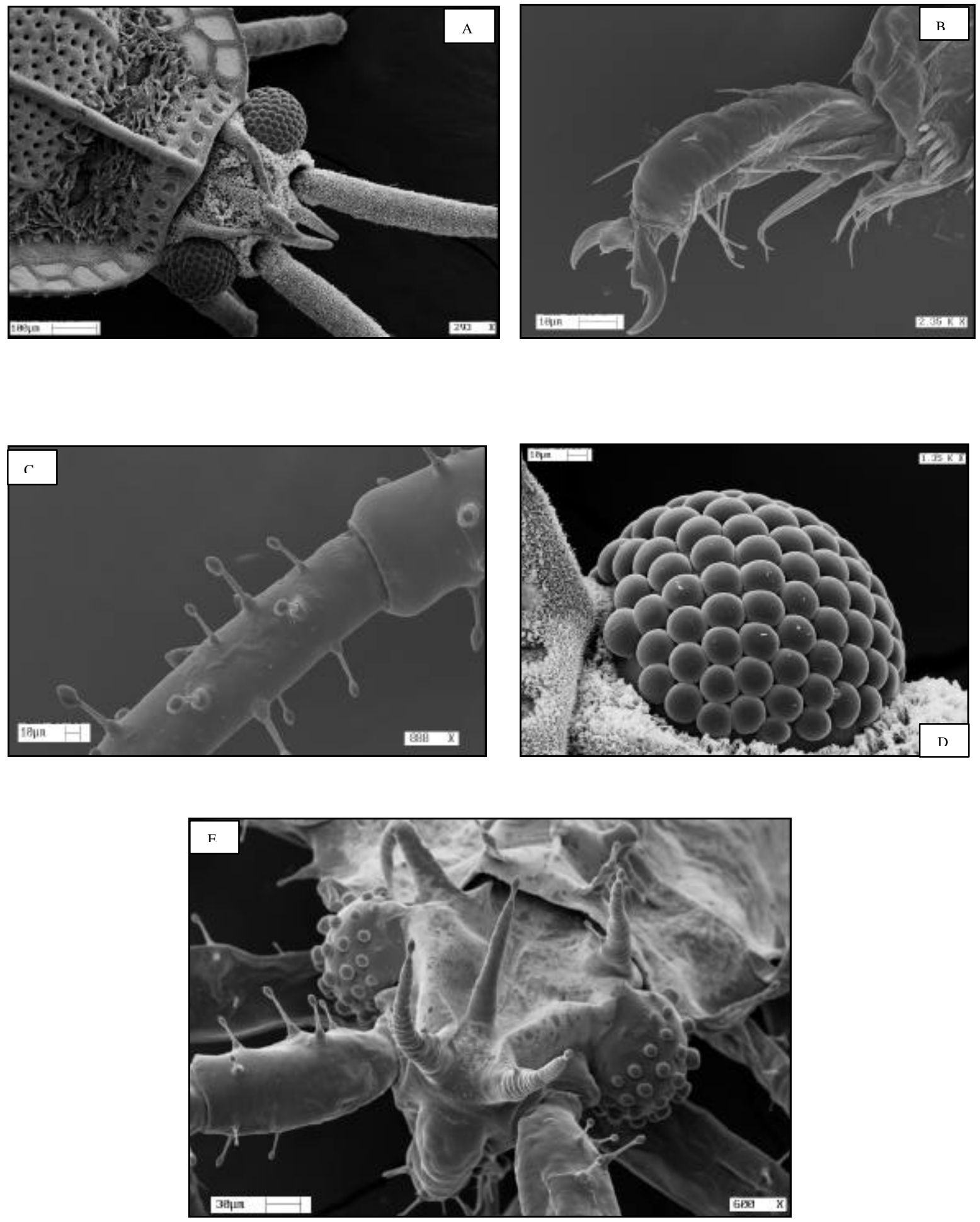

Prancha II 

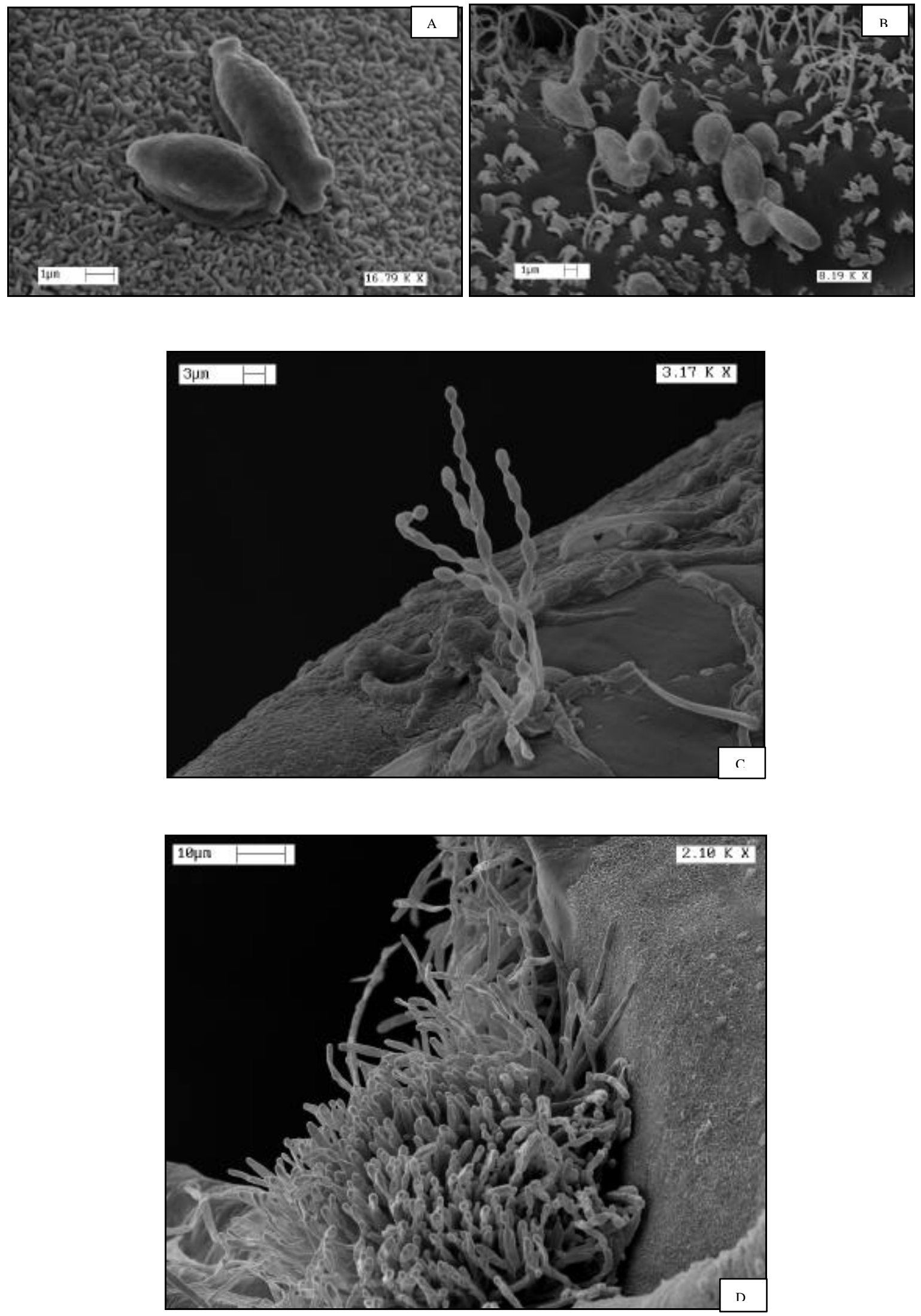

Prancha III 

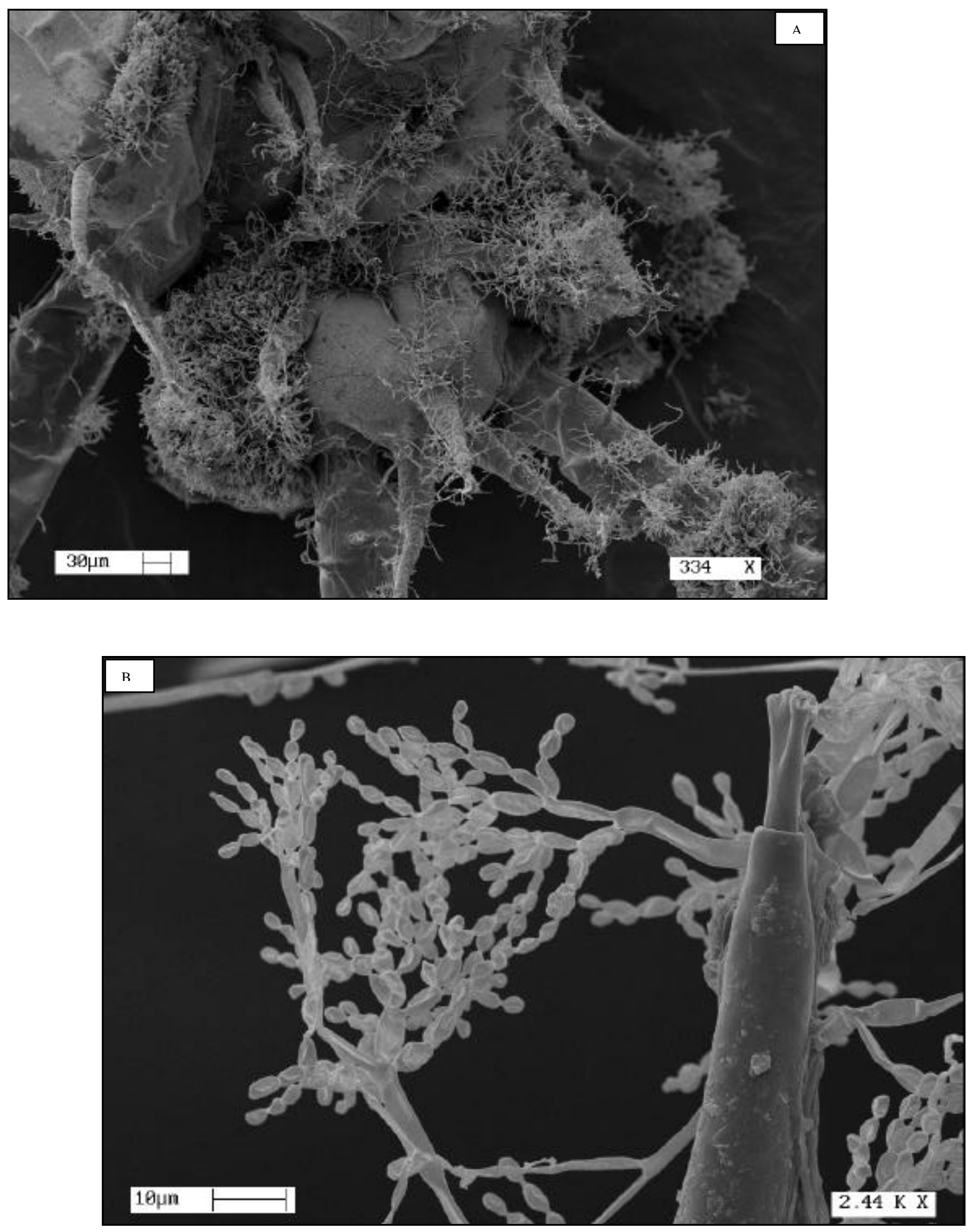

Prancha IV 

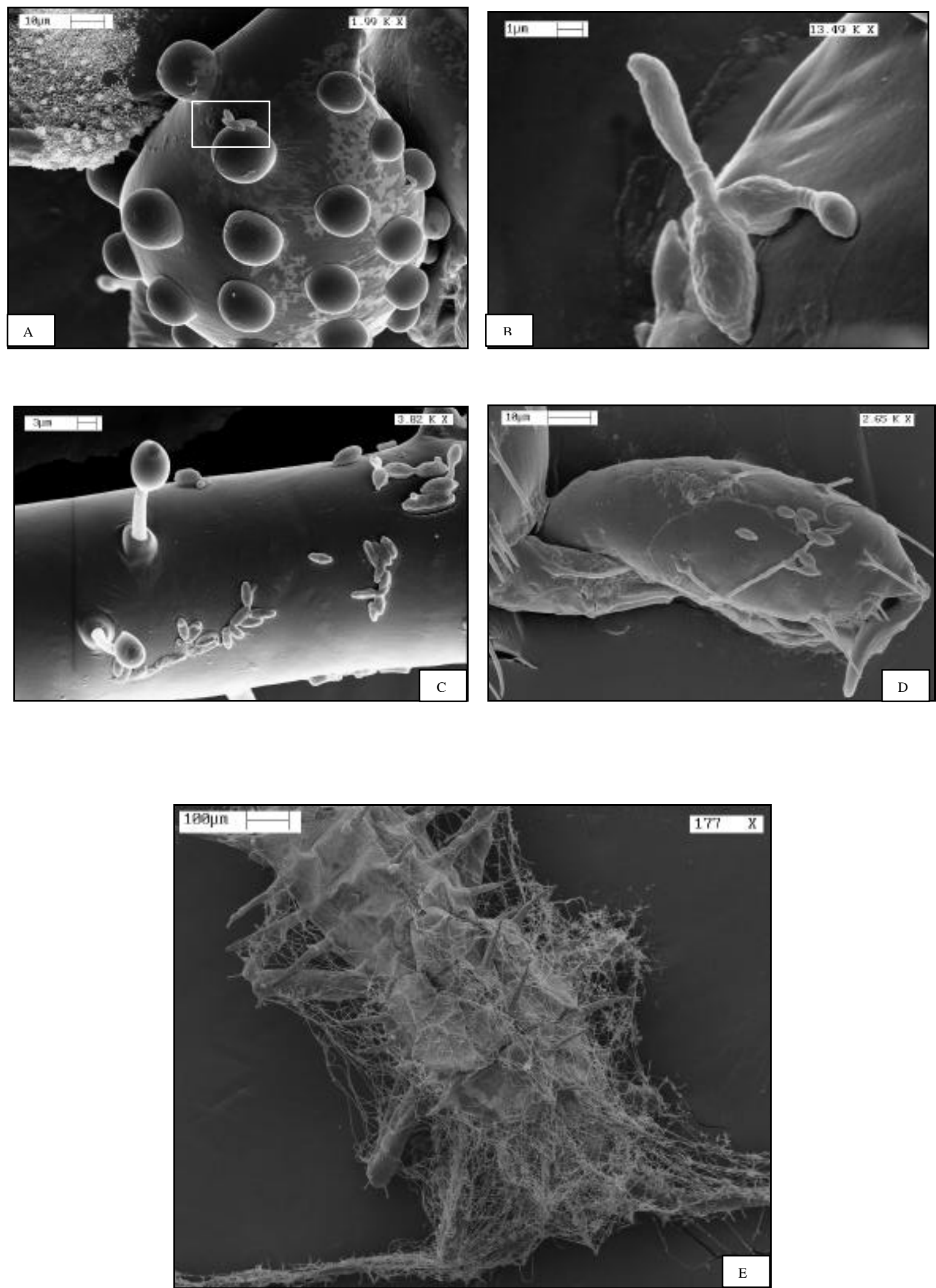

Prancha V 

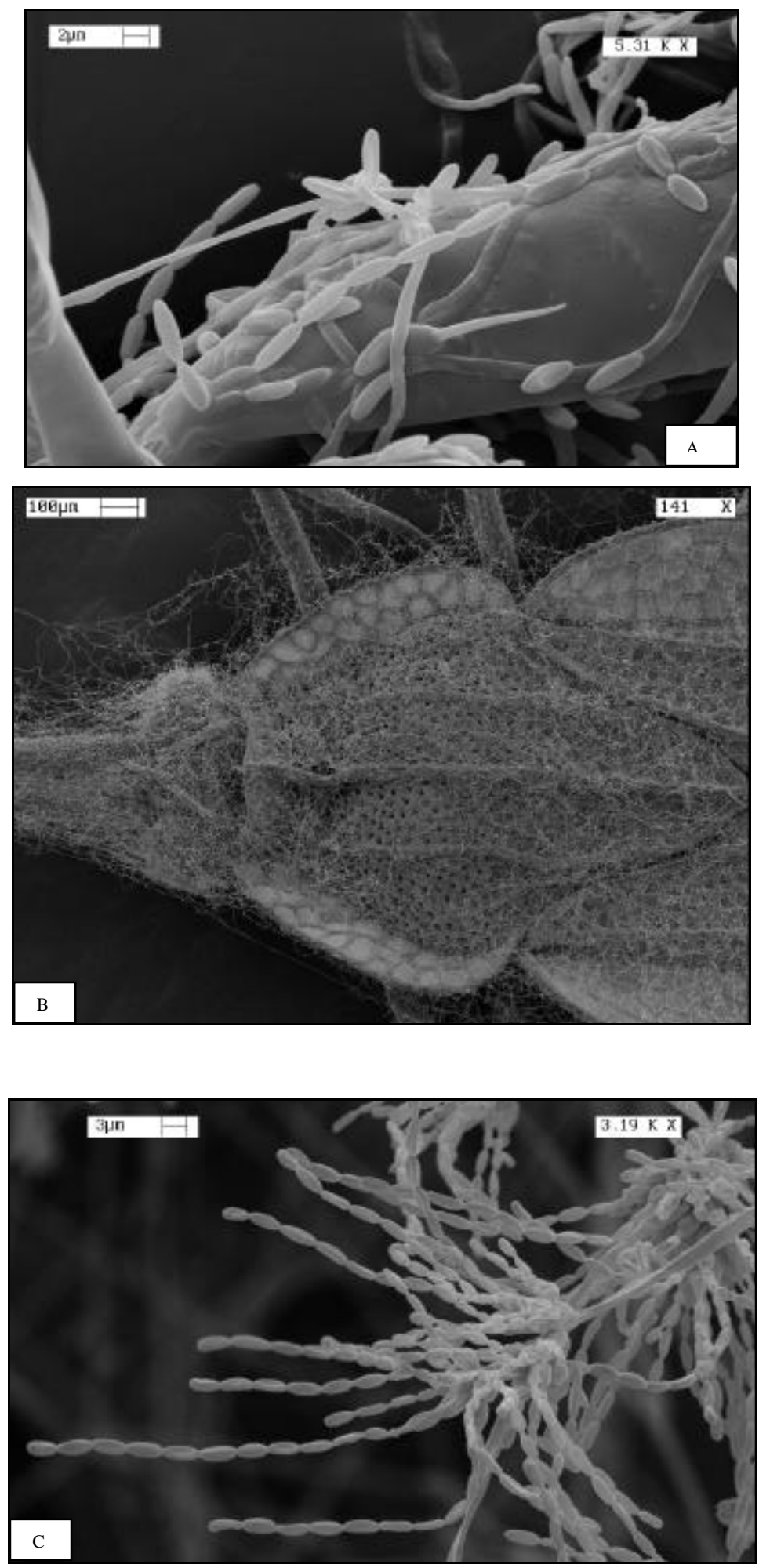

Prancha VI 

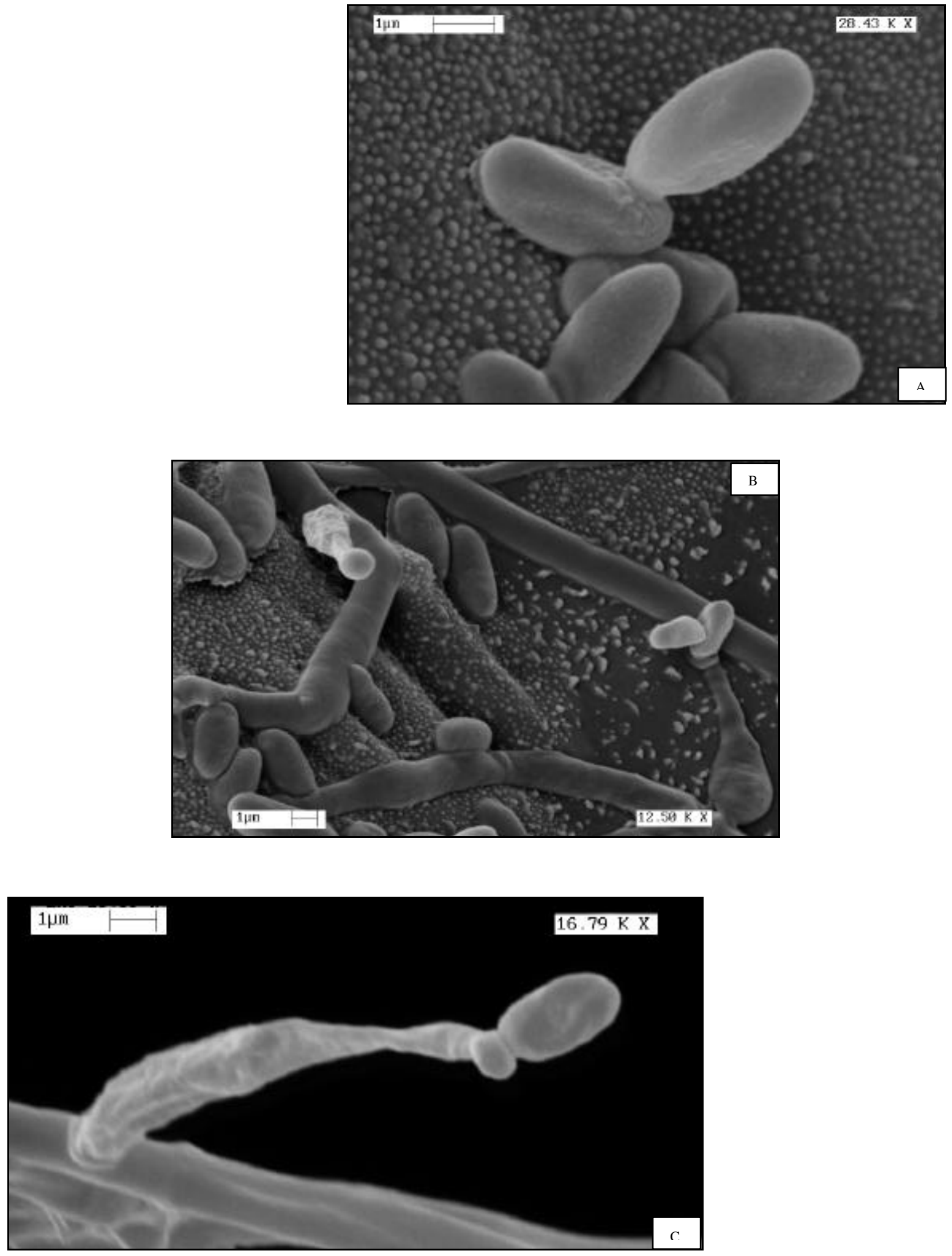

Prancha VII 

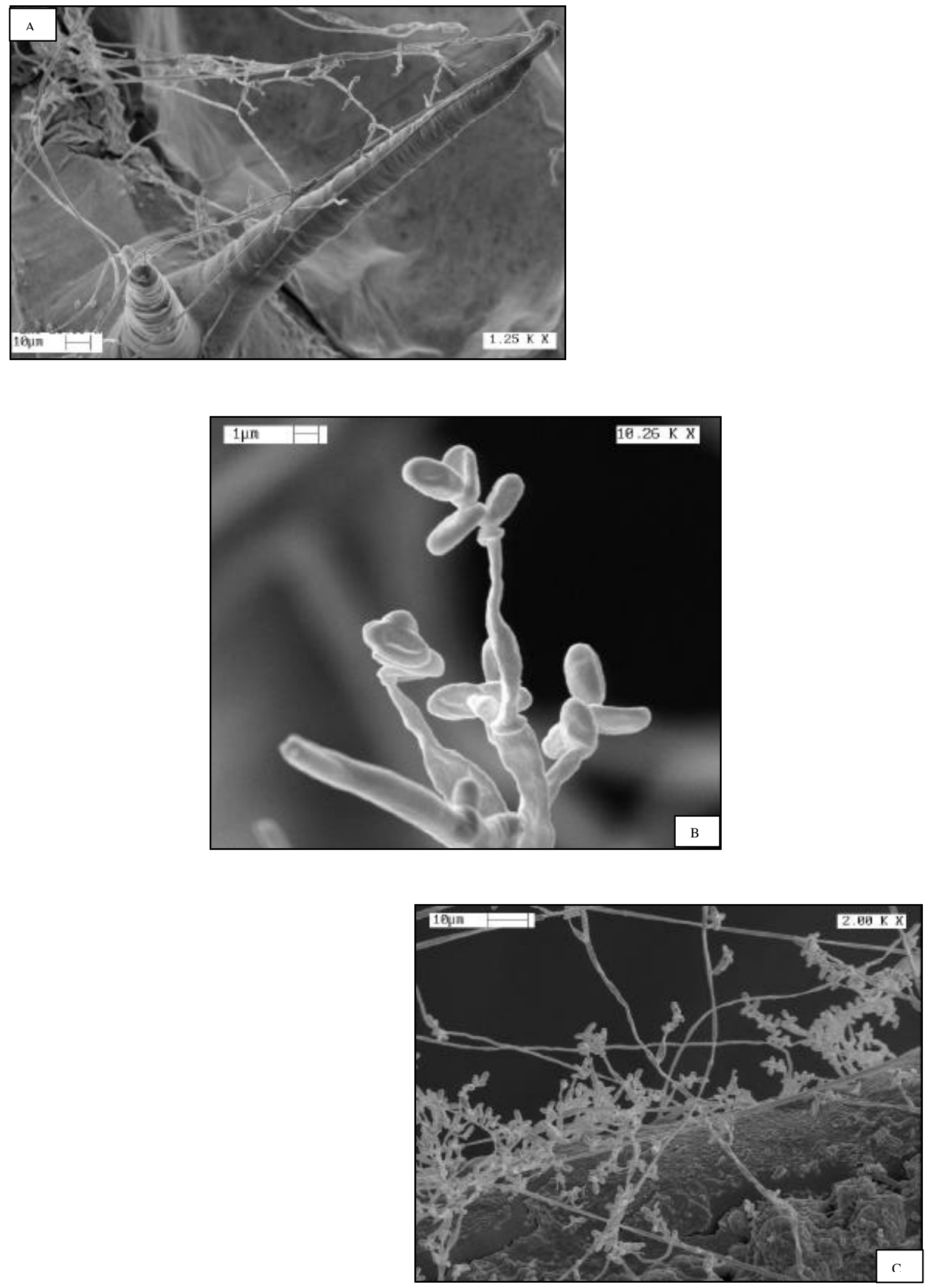

Prancha VIII 

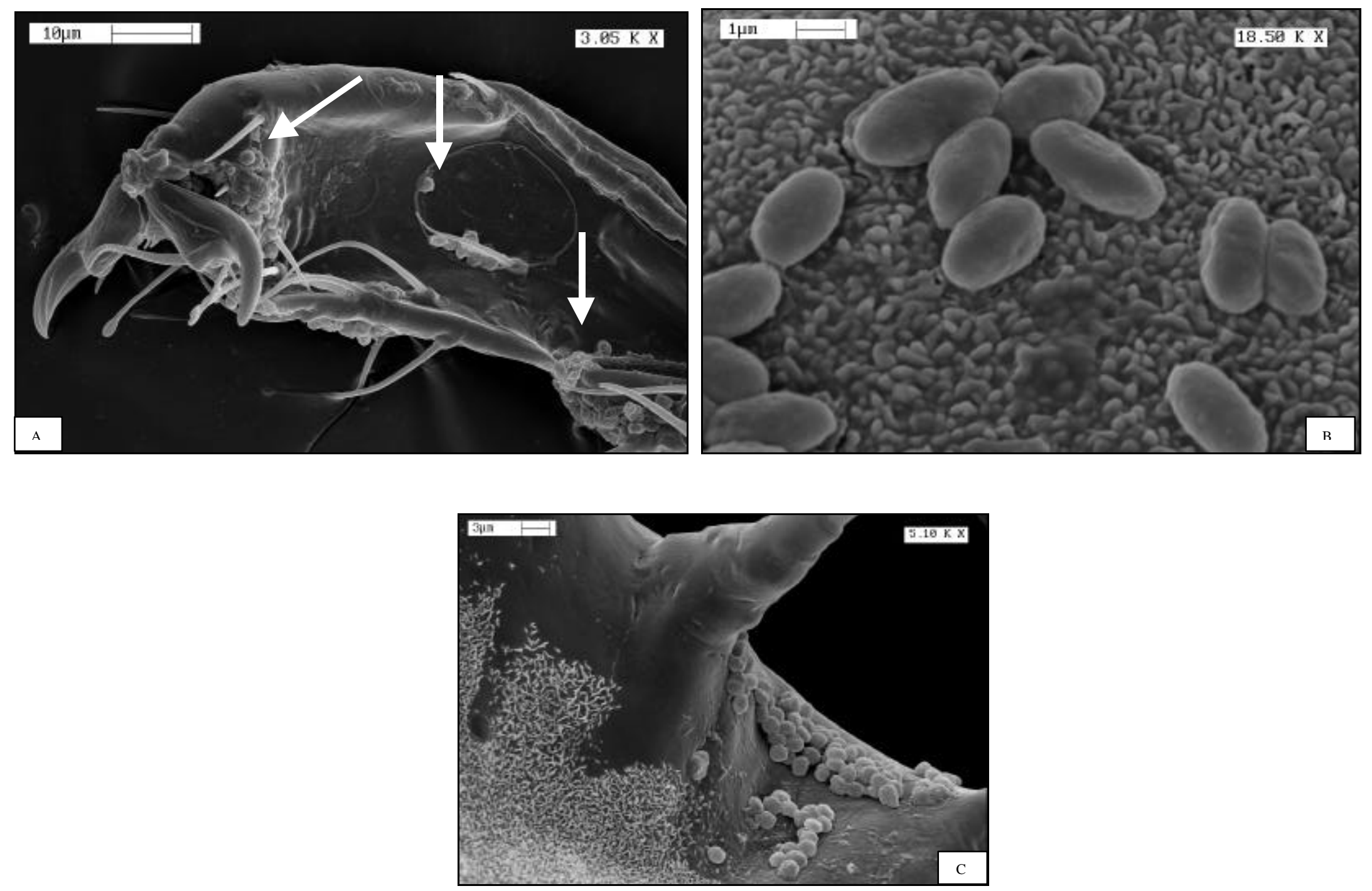

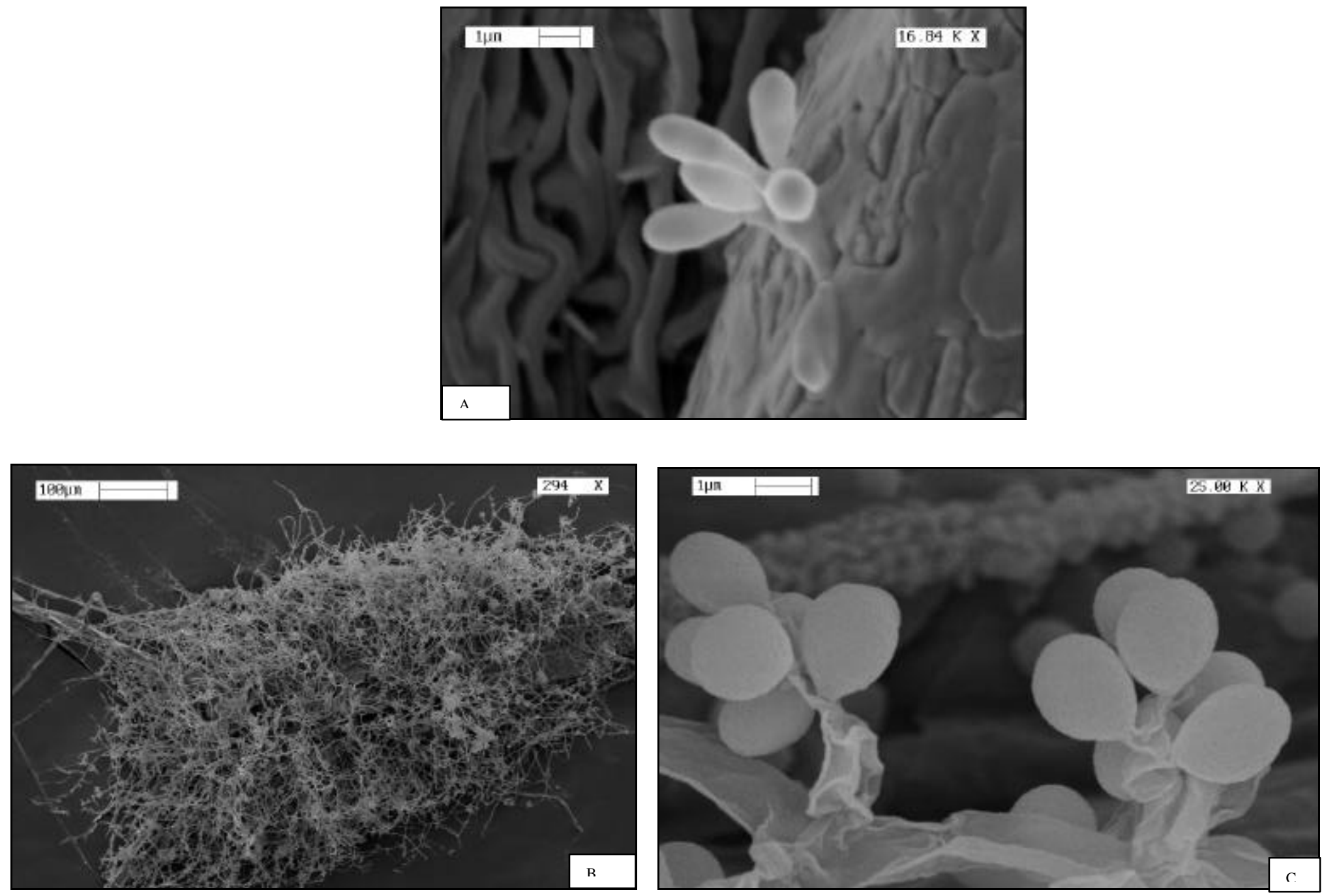

Prancha X 

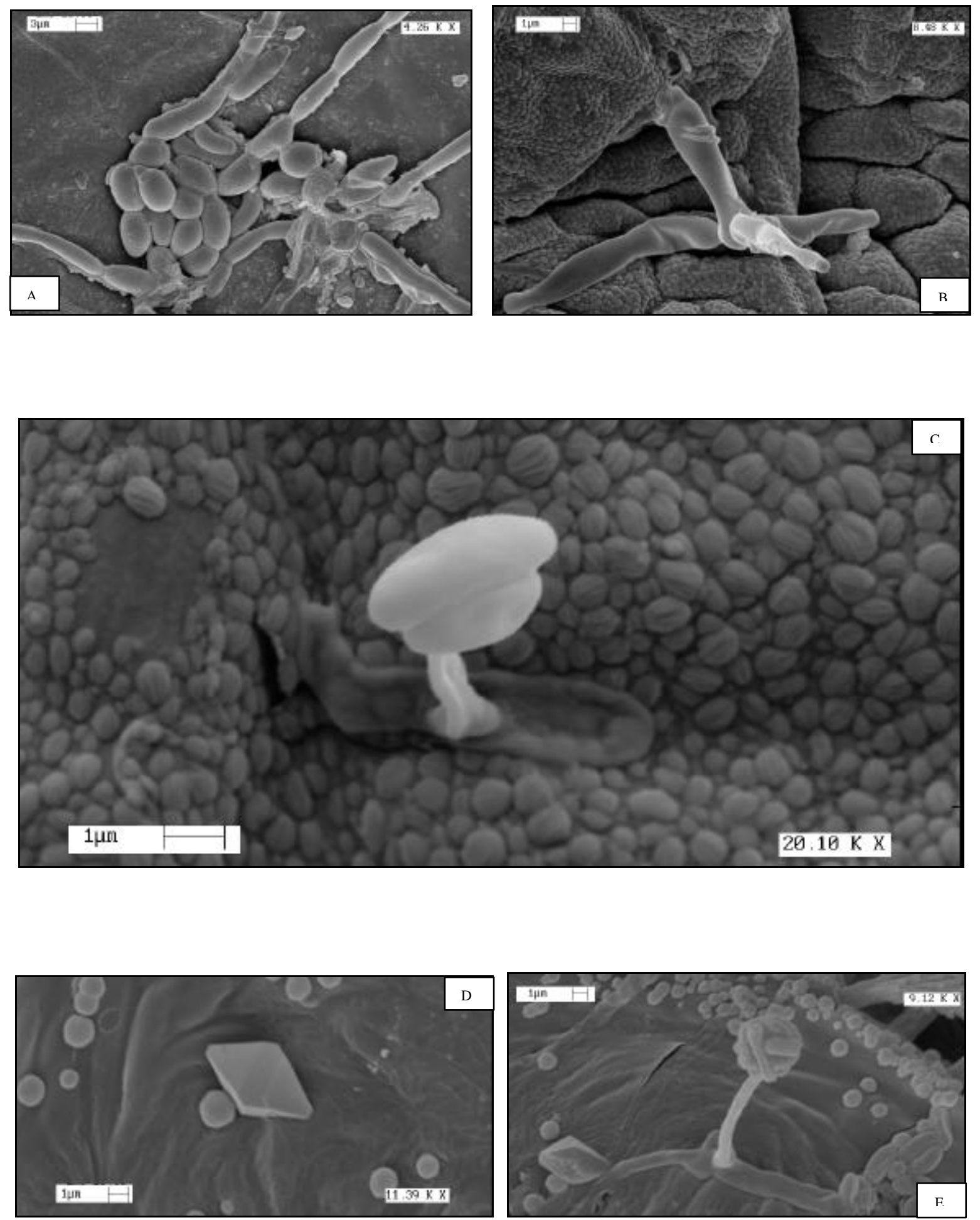

Prancha XI 

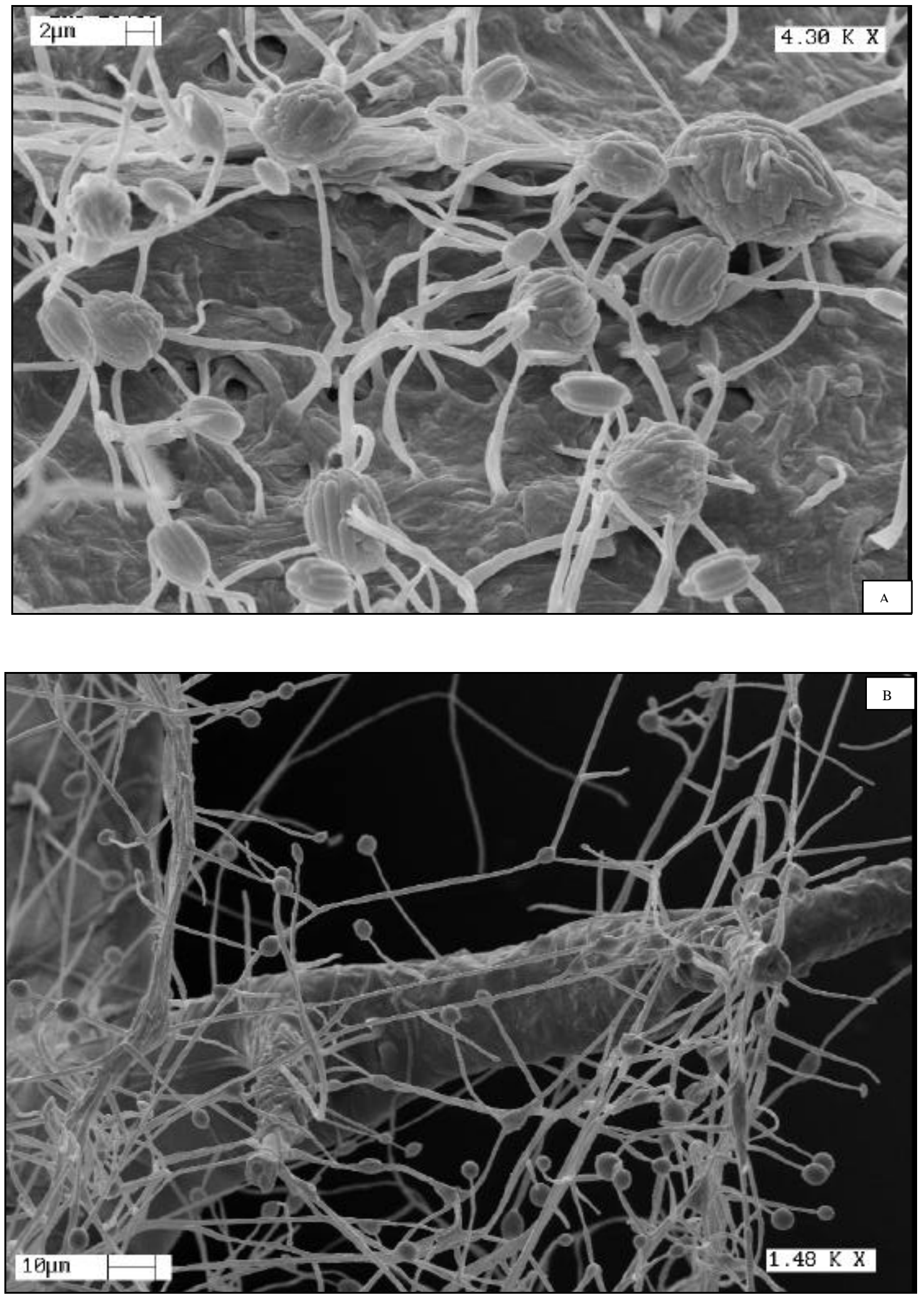

Prancha XII 


\section{CONCLUSÕES GERAIS}

- Nos estudos de epizootiologia de fungos sobre o percevejo-de-renda-daseringueira, durante dois anos em Pindorama-SP, ocorreu uma epizootia de Sporothrix sp. nos meses de agosto e setembro de 1998 nos clones RRIM 600, PR 107, PB 235 e GT 1.

- Nos estudos de epizootiologia de fungos sobre o percevejo-de-renda-daseringueira, durante dois anos em Pindorama-SP, ocorreu uma epizootia de Sporothrix sp. nos meses de agosto e setembro de 1998 nos clones RRIM 600, PR 107, PB 235 e GT 1.

- O fungo Sporothrix sp. pode colonizar o percevejo-de-renda-da-seringueira mesmo após a aplicação do produto Lannate (methomyl).

- A ocorrência de Sporothrix sp. inicia-se a partir da ocorrência da elevada densidade populacional da praga (56 ninfas e 18 adultos/folha).

- Os melhores isolados de fungos entomopatogênicos para controle de Leptopharsa heveae são Metarhizium anisopliae (1144 e E6), Paecilomyces fumosoroseus (1200), Sporothrix insectorum (1229), Beauveria bassiana (1196) e Verticillium lecanii (972).

- O fungo Trichoderma sp., um parasita de muitos fungos fitopatogênicos, causa mortalidade de $78 \%$ em L. heveae.

- No controle de L. heveae com B. bassiana e M. anisopliae em condições de campo devem ser usadas as concentrações iguais ou superiores a $4 \mathrm{Kg}$ de fungo/ha contendo $10^{12}$ e $10^{13}$ conídios/ha, respectivamente. 
- As eficiências de mortalidade são comumente observadas a partir de 20 dias após aplicação em Itiquira-MT e Caçú-GO.

- Os fungos P. fumosoroseus (1200), B. bassiana (447) e M. ansiopliae (1175 e 1144) são os mais eficientes para controle de L. heveae.

- Os produtos Decis 25 CE (0,2 L/ha) e Nuvacron (0,4L/ha) são compatíveis com B. bassiana (619).

- O fungo V. lecanii (972) foi compatível com Nuvacron, Dipterex 500 (0,9 L/ha), Marshal 200 SC (0,15 L/ha), Stron (1,0 L/ha) e Karatê 50 CE (0,45 L/ha).

- Todas as formulações testadas são muito tóxicas para M. anisopliae (1144).

- O fungo M. anisopliae (1189) foi suscetível com os produtos Dipterex, Marshal e Stron.

- Nuvacron e Stron são compatíveis com B. bassiana (1196), P. fumosoroseus (1200) e S. insectorum (1229).

- Marshal foi compatível com B. bassiana (1196) e S. insectorum (1229).

- Dipterex não afetou P. fumosoroseus (1200).

- Não existe diferença entre os meios líquidos a base de BDA e MC para produção de B. bassiana, $M$. anisopliae, $P$. fumosoroseus, S. insectorum e $V$. lecanii.

- O fungo B. bassiana produz $10^{9}$ conídios/mL nos meios líquidos BDA e MC, enquanto que $M$. anisopliae, S. insectorum, P. fumosoroseus e $V$. lecanii produzem $10^{7}$ conídios/mL.

- O método da caixa foi mais produtivo para os fungos $P$. fumosoroseus e $B$. bassiana. 
- No método da bandeja, B. bassiana foi o mais produtivo.

- Os fungos $M$. anisopliae, $B$. bassiana, $V$. lecanii, $S$. insectorum e $P$. fumosoroseus apresentam um ciclo biológico semelhante sobre L. heveae.

- A adesão, germinação e início da penetração desses fungos, ocorre em 24 h após a aplicação sobre ninfas do $4^{\circ}$ ínstar do percevejo-de-renda-da-seringueira.

- O crescimento vegetativo dos fungos estudados sobre essa praga ocorre de 48 a $72 \mathrm{~h}$.

- Após 96 h da aplicação dos patógenos sobre L. heveae ocorre a conidiogênese. 


\section{REFERÊNCIAS BIBLIOGRÁFICAS}

ALMEIDA, J.E.M. de; ALVES, S.B.; PEREIRA, R.M. Selection of Beauveria spp. isolates for control of the termite Heterotermes tenuis (Hagen, 1858). Journal Applied of Entomology, v.121, p.539-543, 1997.

ALMEIDA, J.E.M.; ALVES, S.B.; MOINO JR., A.; LOPES, R.B. Controle de cupins Heterotermes tenuis (Hagen) usando iscas termitrap com inseticida associados com fungos entomopatogênicos Beauveria bassiana (Bals.) Vuill. Anais da Sociedade Entomológica do Brasil, v.27, n.4, p.639-644, 1998.

ALVES, S.B. Efeito tóxico de defensivo in vitro sobre patógenos de insetos. Piracicaba, 1978. 66p. Dissertação (Mestrado) - Escola Superior de Agricultura "Luiz de Queiroz", Universidade de São Paulo.

ALVES, S.B. Controle microbiano de insetos. São Paulo: Manole. 1986. 407p.

ALVES, S.B. (Ed.) Controle microbiano de insetos. 2.ed. Piracicaba: FEALQ, 1998a. cap. 1, p.21-38: Patologia e controle microbiano : vantagens e desvantagens.

ALVES, S.B. (Ed.) Controle microbiano de insetos. 2.ed. Piracicaba: FEALQ, 1998b. cap.11, p.289-382: Fungos entomopatogênicos.

ALVES, S.B.; LECUONA, R.E. Epizootiologia aplicada ao controle microbiano de insetos. In: ALVES, S.B. (Ed.) Controle microbiano de insetos. 2.ed. Piracicaba: FEALQ, 1998. cap. 5, p.97-169. 
ALVES, S.B.; PEREIRA, R.M.P. Produção de fungos entomopatogênicos. In: ALVES, S.B. (Ed.) Controle microbiano de insetos. 2.ed. Piracicaba: FEALQ, 1998. cap.27, p. 845-867.

ALVES, S.B.; MOINO JR., A.; ALMEIDA, J.E.M. Produtos fitossanitários e entomopatógenos. In: ALVES, S.B. (Ed.) Controle microbiano de insetos. 2.ed. Piracicaba: FEALQ, 1998. cap. 8, p.217-238.

ALVES, S.B.; PEREIRA, R.M.P. Produção de Metarhizium anisopliae (Metsch.) Sorok. e Beauveria bassiana (Bals.) Vuill. em bandejas. Ecossistema, v.14, p.188-192, 1989.

ALVES,S.B.; MOINO JR., A.; VIEIRA, S.A. Ação tóxica de alguns defensivos agrícolas sobre fungos entomopatogênicos. Ecossistema, v. 18, p.161-170, 1993.

ALVES, S.B.; STIMAC, J.L.; PEREIRA, R.M.; VIEIRA, S.A. Delayed germination of Beauveria bassiana conidia after prolonged storage at low temperatures. In: ANNUAL MEETING SOCIETY FOR INVERTEBRATE PATHOLOGY, 28., Ithaca, 1995. Program and Abstracts. Ithaca: SIP, 1995. p.2.

AMEBTHGAR, V.; LOGANATHAN, M. Incidence of green muscardine fungus, Nomuraea rileyi (Farlow) Samson on Spodoptera litura (Fab.) in soybean, Glycine $\max ($ L.) Merril from Tamil Nadu (India). Journal of Entomological Research, v.22, n.2, p.195-196, 1998.

ANDERSON, T.E.; ROBERTS, D.W. Compatibility of Beauveria bassiana isolates with insecticide formulations used in Colorado potato beetle (Coleoptera: Chrysomelidae) control. Journal of Economic Entomology, v.76, p.1437-1441, 1983.

ANDREI, E. Compêndio de defensivos agrícolas. 6.ed. São Paulo: Organização Andrei, 1999. 672p. 
ARZONE, A.; MARLETTO-OZINO, O.I. Patogenicita di tre deuteromiceti nei confronti di Corythuca ciliata Say (Heteroptera: Tingidae). Redia, v.47, p.195-203, 1984.

ASKARY, H.; BENHAMOU, N.; BRODEUR, J. Ultrastructural and cytochemical characterization of aphid invasion by the hyphomycete Verticillium lecanii. Journal of Invertebrate Pathology, v.74, n.1, p.1-13, 1999.

BASEGGIO, A. Controllo chimico della Corythuca ciliata mediante iniezioni al tronco. Informatore Agrario., v.46, n.41, p.71-74, 1990.

BATISTA FILHO, A.; ALMEIDA, J.E.M.; LAMAS, C. Effect of thiamethoxam (Actara $250 \mathrm{WG}$ ) on entomopathogenic microorganisms. In: INTERNATIONAL CONGRESS OF ENTOMOLOGY, 21., Foz do Iguaçu, 2000 Abstract. Londrina: EMBRAPA Soja, 2000. p.327.

BATISTA FILHO, A.; LEITE, L.G.; SILVEIRA, A.P. Ocorrência da mosca-de-renda, Leptopharsa heveae, em Buritama, SP. Arquivos do Instituto Biológico, v.62, p.81, 1995.

BATISTA FILHO, A.; LEITE, L.G.; ALVES, E.B.; AGUIAR, J.C. Controle de Cosmopolites sordidus (Coleoptera: Curculionidae) por fipronil e seu efeito sobre Beauveria bassiana. Arquivos do Instituto Biológico. v.63, n.2, p.47-51, 1996.

BATISTA FILHO, A.; LEITE, L.G.; LAMAS, C.; MARTINS, A.L.M.; SILVEIRA, L.C.P.; ALVES, L.F.A. Flutuação populacional do percevejo-de-renda Leptopharsa heveae em Pindorama, SP. Arquivos do Instituto Biológico, v.65, supl., p.44, 1998.

BENESI, J.F.C. Principais fatores que interferem na produtividade do seringal em explotação. In: CICLO DE PALESTRAS SOBRE HEVEICULTURA PAULISTA, 1., Barretos, 1998. Anais. Barretos: SAA; APABOR, 1999. p.141-156. 
BIDOCHKA, M.J.; KHACHATOURIANS, G.G. Growth of the entomopathogenic fungus Beauveria bassiana on cuticular components from the migratory grasshopper, Melanoplus sanguinipes. Journal of Invertebrate Pathology, v.59, p.165-173, 1992.

BITTENCOURT, V.R.E.P.; MASCARENHAS, A.G.; FACCINI, J.H.L. Mecanismo de infecção do fungo Metarhizium anisopliae no carrapato Boophilus microplus em condições experimentais. Ciência Rural, v.29, n.2, p.351-354, 1999.

BOUCIAS, D.G.; PENDLAND, J.C. Ultrastructural studies on the fungus, Nomuraea rileyi, infecting the velvetbean caterpillar, Anticarsia gemmatalis. Journal of Invertebrate Pathology, v.39, p.338-345, 1982.

BOUCIAS, D.G.; PENDLAND, J.C.; LATGÉ, J.P. Nonspecific factors involved in attachment of entomopathogenic Deuteromycetes to host cuticule. Applied Environmental Entomology, v.54, p.1795-1805, 1988.

CARRERA, M. Entomologia para você. 4.ed. São Paulo: Edart, 1973. 185p.

CELESTINO FILHO, P.; MAGAlHÃES, F.E.L. Ocorrência do fungo Sporothrix insectorum Hoog \& Evans, parasitando a mosca-de-renda Leptopharsa heveae Drake \& Poor) em seringal de cultivo. Manaus: EMBRAPA, CNPSD, 1986. 2p. (EMBRAPA. CNPSD. Informativo Técnico, 42).

CILLIERS, C.J., NESER, S. Biological control of Lantana camara (Verbenaceae) in South Africa. Agricultural Ecosystem \& Environomental, v.37, n.1, p.57-75, 1991.

CROSS, J.N.A. de; BIDOCHKA, M.J. Effects of low temperature on growth parameters in the entomopathogenic fungus Metarhizium anisopliae. Canadian Journal of Microbiology, v.45, n.12, p.1055-1061, 1999. 
DALL'ÓGLIO, O.T.; PERES FILHO, O.; DUDA, M.J. Flutuação populacional de Leptopharsa heveae Drake \& Poor (Hemiptera: Tingidae) em seringueira no Estado do Mato Grosso. In: CONGRESSO BRASILEIRO DE ENTOMOLOGIA, 17., Rio de Janeiro,1999. Resumos. Rio de Janeiro: SEB, 1999. v.2, p.732.

DANFA, A.; VALK, H.C.H.G van der. Laboratory testing of Metarhizium spp. and Beauveria bassiana on Sahelian non-target arthropods. Biocontrol Science and Technology, v.9, n.2, p.187-198, 1999.

DEVI, P.S.V.; PRASAD, Y.G. Compatibility of oils and antifeedants of plant origin with the entomopathogenic fungus Nomuraea rileyi. Journal of Invertebrate Pathology, v.68, n.1, p.91-93, 1996.

DOBERSKI, J.W. Comparative laboratory studies on three fungal pathogens on the elm beetle Scolytus scolytus. Effect of temperature and humidity on infection by Beauveria bassiana, Metarhizium anisopliae and Paecilomyces farinosus. Journal of Invertebrate Pathology, v.37, p.195-200, 1981.

DORTA, B.; ERTOLA, R.J.; AREAS, J. Characterization of growth and sporulation of Metarhizium anisopliae in solid-substrate fermentation. Enzyme and Microbial Technology, v.19, n.6, p.434-439, 1996.

DRAKE, C.J.; POOR, M.E. An undescribed rubber tingitid from Brazil (Hemiptera). Journal of the Washington Academic Science, v.25, n.6, p.283-284, 1935.

EASWARAMOORTHY, S.; STRONGMAN, D.B.; SANTHALAKSHMI, G. Record of Hirsutella nodulosa Petch from Chilo sacchariphagus indicus (Kapur), sugarcane internode borer in India. Journal of Biological Control., v.11, n.1/2, p.79-80, 1997. 
EKESI, S.; MANIANIA, N.K.; AMPONG, N.K.; ONU, I. Potential of the entomopathogenic fungus, Metarhizium anisopliae (Metsch.) Sorokin for control of the legume flower thrips, Megaluropthrips sjostedti (Trybom) on cowpea in Kenya. Crop Protection, v.17, n.8, p.661-668, 1998.

EMPRESA BRASILEIRA DE ASSISTÊNCIA TÉCNICA E EXTENSÃO RURAL. Manual técnico cultura da seringueira. Brasília, 1983. 218p.

FARGUES, J.; MANIANIA, N.K.; DELMAS, J.C. Infectivity of propagules of Paecilomyces fumosoroseus during in vitro development to Spodoptera frugiperda. Journal of Invertebrate Pathology, v.64, p.173-178, 1994.

FARIA, M.R. de; MAGALHÃES, B.P. O uso de fungos entomopatogênicos no Brasil. Biotecnologia Ciência \& Desenvolvimento, n.22, p.18-21, 2001.

FONSECA, F. S. Exigências térmicas e distribuição vertical de Leptopharsa heveae Drake \& Poor, 1935 (Heteroptera: Tingidae) em seringueira. Jaboticabal, 2001. 89p. Dissertação (Mestrado) - Faculdade de Ciências Agrárias e Veterinárias, Universidade Estadual Paulista "Júlio de Mesquita Filho".

GALLO, D.; NAKANO, O.; SILVEIRA NETO, S.; CARVALHO, R.P.L.; BATISTA, G.C. de; BERTI FILHO, E.; PARRA, J.R.P.; ZUCCHI, R.A.; ALVES, S.B.; VENDRAMIM, J.D. Manual de entomologia agrícola. 2.ed. Piracicaba: Agronômica Ceres, 1988. 649p.

GENTY, P.; GILDARDO LOPEZ, J.; MARIAU, D. Daños de Pestalotiopsis consecutivos a unos ataque de Gargaphia en Colombia. Oléagineux, v.30, n.5, p.199-204, 1975.

GIROLAMI, V.; BATTISTI, R de. Observazioni sulla Beauveria bassiana (Balsamo) Vuill. patogeno della Corythuca ciliata Say. Italia Forestale e Montana, v.34, n.1, p.19-27, 1979. 
GOPALAKRISHNAN, C.; NARAYANAN, K. Epizootiology of Nomuraea rileyi (Farlow) Samson in field populations of Helicoverpa (=Heliothis) armigera (Hubner) in relation to three host plants. Journal of Biological Control, v.3, n.1, p.50-52, 1989.

GOPALAKRISHNAN, C.; ANUSUYA, D.; NARAYANAN, K. In vitro production of conidia of entomopathogenic fungus Paecilomyces farinosus (Holmskiold) Brown and Smith. Entomon, v.24, n.4, p.389-392, 1999.

GRAVENA, S.; YAMAMOTO, P.T.; FERNANDES, O.D.; BENETOLI, I. Effect of ethion and aldicarb on Seleaspidus articulatus (Morgan), Parlatoria ziziphus (Lucas) (Hemiptera: Diaspididae) and influence on beneficial fungi. Anais da Sociedade Entomológica do Brasil, v.21, n.2, p.101-111, 1992.

GRIMM, C; GUHARAY, F. Control of leaf-footed bug Leptoglossus zonatus shieldbacked bug Pachycoris klugii with entomopathogenic fungi. Biocontrol Science and Technology, v.8, n.3, p.365-376, 1998.

HALL, D.G. Sugarcane lace bug Leptodictya tabida, an insect pest new to Florida. Florida Entomologist, v.74, n.1, p.148-149, 1991.

HENDERSON, C.F.; TILTON, E.W. Tests with acaricides against the brown wheat mite. Journal of Economic Entomology, v.48, p.157-161, 1955.

HICKEL, E.R.; DUCROQUET, J.P.H. Pragas da goiabeira serrana (Feiojoa sellowiana): II- percevejo-de-renda (Ulontingis nitor) (Hemiptera: Tingidae). Anais da Sociedade Entomológica Brasileira, v.22, n.1, p.169-173, 1993.

HU, W.; HOU, R.F.N.; TALEKAR, N.S.; HU, W.J. Pathogenicity of Beauveria bassiana to Riptortus linearis (Hemiptera: Coreidae), a pest of soybean. Applied Entomology and Zoology, v.31, n.2, p.187-194, 1996. 
IGNOFFO, C.M.; HOSTETTER, D.L.; GARCIA, C.; PINNEL, R.E. Sensitivity of the entomopathogenic fungus Nomuraea rileyi to chemicals pesticides used on soybeans. Environmental Entomology, v.4, p.765-768, 1975.

INSTITUTO AGRONÔMICO DE CAMPINAS. Importância da cultura. http://www.iac.br rrim600/importcult.htm (24 Set. 2001).

INYANG, E.N.; BUTT, T.M.; DOUGHTY, K.J.; TODD, A.D.; ARCHER, S. The effects of isothiocyanates on the growth of the entomopathogenic fungus Metarhizium anisopliae and is infection of the mustard beetle. Mycological Research, v.103, n.8, p.974-980, 1999.

JACKSON, C.W.; HEALE, J.B.; HALL, R.A. Traits associated with virulence to the aphid Macrosiphoniella sanborni in eighteen isolates of Verticillium lecanii. Annals of Applied Biology, v.106, p.39-48, 1985.

JEFFS, L.B.; XAVIER, I.J.; MATAI, E.R.; KHACHATOURIANS, G.G. Relationships between fungal spore morphologies and surface properties for entomopathogenic members of the genera Beauveria, Metarhizium, Paecilomyces, Tolypocladium and Verticillium. Canadian Journal of Microbiology, v.45, n.11, p.936-948, 1999.

JUNQUEIRA, N.T.V.; GARCIA, M.V.B.; CELESTINO FILHO, P.; MORAES, L.A C. Controle biológico da mosca-de-renda (Leptopharsa heveae) em seringais de cultivo no Estado do Amazonas. In: SIMPÓSIO NACIONAL DE CONTROLE BIOLÓGICO DE PRAGAS E VETORES, 1., Rio de Janeiro, 1988. Resumos. Rio de Janeiro: Fundação Oswaldo Cruz, 1988. p.31. 
JUNQUEIRA, N.T.V.; PINHEIRO, E.; ALVES, R.T.; CELESTINO FILHO, P.; PEREIRA, A.V.; OLIVEIRA, M.A.S.; FIALHO, J.F.; GASPAROTTO. Controle biológico do percevejo-de-renda (Leptopharsa heveae Drake \& Poor) em seringais de cultivo. Planaltina: EMBRAPA, Cerrados, 1999. 30p. (EMBRAPA, Cerrados. Circular Técnica, 3).

JUNQUEIRA, N.T.V.; LIMA, M.M.I.P.; MARTINS, M.A.M.; MAGALHÃES, F.E.L. Isolamento e cultivo do fungo Sporothrix insectorum (Hoog \& Evans), a ser utilizado para o controle da mosca-de-renda da seringueira. Manaus: EMBRAPA, CNPSD, 1987. 4p. (EMBRAPA/CNPSD. Comunicado Técnico, 56).

KNAUF, T.A.; WRIGHT, J.E. Beauveria bassiana (ATCC 74040): control of insect pests in field crops and ornamentals. In: BRIGHTON CROP PROTECTION CONFERENCE, PESTS AND DISEASES, 3., Brighton, 1994. Proceedings. Brighton, 1994. p.1103-1108.

KUFFNER, J.R. Aspectos relevantes dos sistemas de explotação utilizados por pequenos produtores. In: ENCONTRO NACIONAL SOBRE EXPLOTAÇÃO E ORGANIZAÇÃO DE SERINGAIS DE CULTIVO, 1., Brasília, 1986. Anais. Brasília, 1986. p.67-71.

LANGEWALD, J.; OUAMBAMA, Z.; MAMADOU, A.; PEVELING, R.; STOLZ, I.; BATEMAN, R.; ATTIGNON, S.; BLANFORD, S.; ARTHURS, S; LOMER, C. Comparison of an organophosphate insecticide with a mycoinsecticide for the control of Oedaleus senegalensis (Orthoptera: Acrididae) and other Sahelian grasshoppers at an operational scale. Biocontrol Science and Technology, v.9, n.2, p.199-214, 1999.

LEITE, L.G.; BATISTA FILHO, A.; BERGMANN, E.C.; IMENES, S.D.L.; OLIVEIRA, S.M.C. de. Pathogenicity of the fungus Sporothrix insectorum on nymphs and adults of Stephanitis pyrioides (Heteroptera: Tingidae). Arquivos do Instituto Biológico, v.65, n.2, p.123-125, 1998. 
LENTEREN, J.C. van; ROSKAM, M.M.; TIMMER, R. Commercial mass production and pricing of organisms for biological control of pests in Europe. Biological Control, v.10, p.143-149, 1997.

LI CHANG, T.; HOU, R.F. Potential application of the entomopathogenic fungus, Nomuraea rileyi, for control of the corn earworm, Helicoverpa armigera. Entomologia Experimentalis et Applicata, v.88, n.1, p.25-30, 1998.

LIMA, A.F.; RACCA FILHO, F. Ocorrência de Ulontigis brasiliensis (Drake, 1922) no Estado do Rio de Janeiro (Hemipera: Tingidae). In: CONGRESSO BRASILEIRO DE ENTOMOLOGIA, 13., Recife, 1991. Resumos. Recife: SEB, 1991. p.136.

LIVINGSTONE, D.(Ed.) Insects and host specificity. 1977. p.23-28: Host specificity in Tingidae (Heteroptera) in relation to plants, parasitoids and predators.

LIVINGSTONE, D., JEYANTHI-BAI, S.; YACOOB, M.; BAI, S.J. Functional amatomy of the egg and nymphal morphology of the grass tingid Agramma hypehanum (Drake \& Maa) (Heteroptera: Tingidae) with a note on its egg parasites. Journal of the Bombay Natural History Society, v.85, n.3, p.482-488, 1985.

LIVINGSTONE, D.; YACOOB, M.H.S. Natural enemies and biologies of the egg parasitoides of Tingidae in southern India. Uttar Pradesh Journal of Zoology, v.6, n.1, p.1-21, 1986.

LOPES, R.B. Seleção de fungos entomopatogênicos e controle de Frankliniella occidentalis (Thysanoptera: Thripidae). Piracicaba, 1999. 72p. Dissertação (Mestrado) - Escola Superior de Agricultura “Luiz de Queiroz”, Universidade de São Paulo. 
LOPEZ, L.L.V.; CARBONELL, T. Use of almond mesocarp for production of the entomopathogenic fungus Verticillium lecanii. Canadian Journal of Microbiology, v.44, n.9, p.886-895, 1998.

LOPEZ; L.L.V.; CARBONELL, T. Characterization of Spanish strains of Verticillium lecanii. Revista Iberoamericana, v.16, n.3, p.136-142, 1999.

LOPEZ, L.L.V.; CARBONELL, T.; SALINAS, J. Colonization of plant waste substrates by entomopathogenic and mycoparasitic fungi- a SEM study. Micron, v.30, n.4, p.325-333, 1999.

LUZ, C.; TIGANO, M.S.; SILVA, I.G.; CORDEIRO, C.M.T; ALJANABI, S.M. Selection of Beauveria bassiana and Metarhizium anisopliae isolates to control Triatoma infestans. Memórias do Instituto Oswaldo Cruz, v.93, n.6, p.839-846, 1998.

MACHADO, V.; DIEHL , F.E.; SILVA, M.E. da; LUCCHESE, M.E.P. de. Reações observadas em colônias de alguns espécies de Acromyrmex (Hymenoptera: Formicidae) quando inoculados com fungos entomopatogênicos. Ciência e Cultura, v.40, n.11, p.1106-1108, 1988.

MAGALHÃES, B.P.; LECOQ, M.; FARIA, M.R. de; SCHMIDT, F.G.V.; GUERRA, W.D. Field trial with the entomopathogenic fungus Metarhizium anisopliae var. acridum against bands of the grasshopper Rhammatocerus schistocercoides in Brazil. Biocontrol Science and Technology, v.10, n.4, p.427-441, 2000.

MANIANIA, N.K.; FARGUES, J. Susceptibility of Mamestra brassicae (L.), and Spodoptera littoralis (Boisd.) larvae (Lep., Noctuidae) to the hyphomycetes Paecilomyces fumosoroseus (Brown ans Smith) and Nomureae rileyi (Samson) at two temperatures. Journal of Applied Entomology, v.113, n.5, p.518-524, 1992. 
MANZINI, A.R.C.; ALVES, S.B.; LOPES, R.B.; ALVES, L.F.A. Seleção de isolados e estratégia de aplicação de fungos entomopatogênicos para o controle de Blatella germanica. In: SIMPÓSIO DE INCIAÇÃO CIENTÍFICA DA UNIVERSIDADE DE SÃO PAULO, 6., Piracicaba, 1998. Resumos. Piracicaba: USP, 1998. p.503.

MARIAU, D. Control methods against the bug Pestalotiopsis complex oil palm in Latin America. Oleagineux, v.49, n.4, p.189-195, 1994.

MARLETTO-OZINO, O.I.; ARZONE, A. Ruolo di temperatura e umidita nell'azione di deuteromiceti patogeni su Corythuca ciliata (Say) (Rhynchota: Tingidae). Diffesa Piante,v.8, n.2, p.321-327, 1985.

MARTIN, N.B.; ARRUDA, S.T. A produção de borracha natural: Situação atual e perspectivas. Informativo Econômico, v.23, n.9, p.1-47, 1993.

MARTINS, J.F. da S.; LIMA, M.G.D. de. Entomopathogenic fungi fot the control of rice stem bug Tibraca limbativentris Stal.: virulence of isolates of Metarhizium anisopliae (Metsch.) Sorok. and Beauveria bassiana (Bals.) Vuill. Anais da Sociedade Entomológica do Brasil, v.23, n.1, p.39-44, 1994.

MAURI, G. Essai de lutte contre le tigre americain du platane (Corythucha ciliata) par des injections aux arbres. Revue Horticole Suisse, v.62, n. 6, p.165-170, 1989.

MAY, A.; GONÇALVES, P.S.; BRIOSCHI, A.P. Consorciação de seringueira com culturas de importância econômica. O Agronômico, v.51, n.1, p-16-23, 1999.

McCOY, C.W.; LYE, B.H. Effect of cooper sprays on the population dynamics of the citrus mite, Phyllocoptruta oleivora (Acari: Eriophyidae) and its fungal pathogen, Hirsutella thompsonii. Proceedings of the Florida State for Horticultural Society, v.108, p.126-129, 1996. 
MELO, I.S. de. Agentes microbianos de controle de fungos fitopatogênicos. In: MELO, I.S. de; AZEVEDO, J.L. de (Ed.). Controle biológico, Jaguariúna: EMBRAPA, 1998. p.20-67.

MELLO PEREIRA, S.R. de; FERREIRA da EIRA, A. Metodologia para produção de Metarhizium anisopliae (Metsch.) Sorokin em cultivo submerso: esporulação da biomassa, efeito da concentração de açúcar e custo do inoculante. Ciência Rural, v.29, n.3, p.389-394, 1999.

MISHRA, S.C.; SEN-SARMA, P.K. Host specificity test and a note on life history of Leptobyrsa decora Drake (Hemiptera: Tingidae) on teak. Bullettin Entomological, v.27, n.2, p.81-86, 1986.

MOINO JR., A.; ALVES, S.B. Determinação de concentrações de Beauveria bassiana (Bals.) Vuill. para o controle de insetos-pragas de grãos armazenados. Anais da Sociedade Entomológica do Brasil, v.26, n.1, p.15-20, 1997.

MOINO JR, A.; ALVES, S.B. Efeito de imidacloprid e fipronil sobre Beauveria bassiana (Bals.) Vuill. e Metarhizium anisopliae (Metsch.) Sorok. e no comportamento de Heterotermes tenuis (Hagen). Anais da Sociedade Entomológica do Brasil, v.27, n.4, p.611-619, 1998.

MOINO JR., A.L; ALVES, S.B.; PEREIRA, R.M. Efficacy of Beauveria bassiana (Balsamo) Vuillemin isolates for control of stored-grain pests. Journal of Applied Entomology, v.122, p.301-305, 1998.

MOINO JR., A.; SAAD, M.C.; ALVES, S.B. Ação tóxica de defensivos utilizados na cultura dos citros sobre fungos entomopatogênicos. In: CONGRESSO DE INICIAÇÃO CIENTÍFICA DA ESALQ, 4., Piracicaba, 1989. Resumos. Piracicaba: ESALQ, 1989. p.53. 
MONTE, O. Catálogo dos tingídeos do Brasil. Arquivos de Zoologia, v.2, p.65-174, 1940.

MOREIRA, I.P.S. A Leptopharsa heveae (Drake \& Poor) e seus danos às mudas de Hevea brasiliensis (Muell.). Curitiba, 1985. 48p. Dissertação (Mestrado) - Universidade Federal do Paraná.

MORRIS, M.J.; ROBERTS, S.J.; MADDOX, J.V.; ARMBRUST, E.J. Epizootiology of the fungal pathogen, Zoophthora phytonomi (Zygomycetes: Entomophthorales) in field populations of alfafa weevil (Coleoptera: Curculionidae) larvae in Illinois. Great Lakes Entomologist, v.29, n.3, p.129-140, 1996.

NAHAS, E.; ARAI, N. N. S. Crescimento e esporulação de Beauveria bassiana em vários meios e condições de cultivo. Revista Microbiologia, v.18, n.1, p.77-82, 1987.

NEAL JR., J.W.; DOUGLASS, L.W. Development, oviposition rate, longevity, and voltinism of Stephanitis pyrioides (Heteroptera: Tingidae), an adventive pest of azalea, at three temperatures. Environmental Entomology, v.17, n.5, p.827-831, 1988.

NEAL JR., J.W.; DOUGLASS, L.W. Seasonal dynamics and the effect of temperature in Corythuca cydoniae (Heteroptera: Tingidae). Environmental Entomology, v.19, n.5, p.1299-1304, 1990.

NEVES, P.O.M.J. Controle associado de Cornitermes cumulans (Kollar, 1832) (Isoptera: Termitidae) com fungos entomopatogênicos e o inseticida imidacloprid. Piracicaba, 1998. 111p. Tese (Doutorado) - Escola Superior de Agricultura "Luiz de Queiroz", Universidade de São Paulo.

NORTON, R.A.; BEHAN-PELLETIER, V.M. Calcium carbonate and calcium oxalate as cuticular hardening agents in oribatid mites. Canadian Journal of Zoology, v.69, p.1504-1511, 1991. 
ODONGO, B.; ODINDO, M.O.; BROWNBRIDGE, M.; KUMAR, R. Comparative biological efficacy of Hirsutella thompsonii and Neoseiulus teke for cassava mite (Mononychellus tanajoa) supression. Biocontrol Science and Technology, v.8, n.3, p.345-355, 1998.

OLIVEIRA, M.A.S.; JUNQUEIRA, N.T.; FIALHO, J.F.; ICUMA, M.I. Patogenicidade de fungos entomopatogênicos sobre o percevejo-de-renda Vatiga illudens Drake (Hemiptera: Tingidae) na cultura da mandioca no Distrito Federal. In: CONGRESSO BRASILEIRO DE ENTOMOLOGIA, 17., Rio de Janeiro, 1998. Resumos. Rio de Janeiro: SEB, 1998. v.1, p.69.

OLIVER, J.E.; NEAL, J.W. JR.; LUSBY, W.R. Novel components from secretory hairs of azalea lace bug Stephanitis pyrioides (Hemiptera: Tingidae). Journal of Chemical Ecology, v.11, p.1123-1228, 1985.

OMOTO, C.; ALVES, S.B. Mecanismos de defesa de insetos contra entomopatógenos. In: ALVES, S.B. (Ed.) Controle microbiano de insetos. 2.ed. Piracicaba: FEALQ, 1998. cap. 3, p.55-74.

ORDONEZ GIRALDO, A.I.D.H. Sporothrix insectorum: méthode biologique de contrôle de la punaise Leptopharsa gibbicarina dans les cultures du palmier à huile en Amérique Latine (Hemiptera, Tingidae). Bulletin de la Société Entomologique de France, v.98, n.1, p.77-85, 1993.

PADIN, S.B.; BELLO, G.M. dal; VASICEK, A.L. Bioinsecticide potential of entomopathogenic fungi for stored gain pests. Revista de la Facultad de Agronomia Universidad de Buenos Aires, v.15, n.1, p.1-7, 1996. 
PAPACEK, D.; SMITH, D. Manejo integrado de pragas nos citros: linhas gerais de um programa comercial de MIP em Queensland, Austrália. In: SEMINÁRIO INTERNACIONAL DE CITROS-MIP, 3., Bebedouro, 1994. Anais. Bebedouro: FUNEP, 1994. p.153-175.

PECORA, P.; RIZZA, A.; STAZI, M. Biology and host specificity of Oncochila simplex (Hem.: Tingidae), a candidate for the biological control of leafy spurge Euphorbia esula L. “complex”. Entomophaga, v.37, n.1, p.79-89, 1992.

POPRAWSKI, T.J.; PARKER, P.E.; TSAI, J.H. Laboratory and field evaluation of hyphomycete insect pathogenic fungi for control of brown citrus aphid (Homoptera: Aphididae). Environmental Entomology, v.28, n.2, p.315-321, 1999.

RAMOSKA, V.A. The influence of relactive humidity an Beauveria bassiana infectivity, and replication in the chinch bug Blissus leucopterus. Journal of Invertabrate Pathology, v.43, p.389-394, 1984.

RARAMAJE, N.V.U.; GOVINDU, H.C.; SHASTRY, K.S.S. The effect of certain insecticides on the entomogenous fungi Beauveria bassiana and Metarhizium anisopliae. Journal of Invertebrate Pathology, v.9, p.398-403, 1967.

RATH, A.C. The use of entomopathogenic fungi for control of termites. Biocontrol Science and Technology, v.10, n.5, p.563-581, 2000.

REBOLLAR, A.A.; ALATORRE, R.R.; MENDOZA, C. Evaluacion in vitro de fungicidas sobre el hongo entomopatogeno Verticillium lecanii (Zimm.) Viegas. Revista Mexicana de Fitopatologia, v.12, n.2, p.189-193, 1994.

REYES, A.I.C.; BUSTILlO, P.A.E.; CHAVES, C.B. Effect of Beauveria bassiana and Metarhizium anisopliae on the coffee berry parasitoid Cephalonomia stephanoderis. Revista Colombiana de Entomologia, v.21, n.4, p.199-204, 1995. 
REYES, A.R.; CRUZ, M.A.; GENTY, P. Technique d'absorption racinaire pour le controle des ravageurs du palmier a huile. Oleagineux, v.43, n.10, p.363-370, 1988.

ROBERTS, D. W.; SWEENEY, A. W. Production of fungi imperfecti with vector control potencial. In: INTERNATIONAL COLLOQUIUM ON INVERTEBRATE PATHOLOGY, 3., Falher, 1982. Proceedings. Falher: University of Sussex, 1982. p.409-413.

ROBERTS, D. W.; YENDOL, W. Use o fungi for microbial control of insects. In: BURGES, H. D.; HUSSEY, N. W. Microbial control of insects and mites, , New York: Academic Press, 1981. p. 125-149.

RODRIGUES, M.G. Pragas da seringueira. Manaus: EMBRAPA, CNPSD, 1977. n.p. (Curso intensivo de heveicultura para técnicos agrícolas patrocinado pela SUDHEVEA).

RU, B. le. Epizootiology of fungus Neozygites fumosa (Zygomycetes, Entomophthorales) in a population of cassava mealybug, Phenacoccus manihoti (Hom.: Pseudococcidae). Entomophaga, v.31, n.1, p.79-89, 1986.

RU, B. le; IZIQUEL, Y. New observations on the epizootiology of Neozygites fumosa in populations of the cassava mealybug Phenacoccus manihoti. Entomophaga, v.35, n.2, p.173-183, 1990.

SAMSINAKOVA, A.; KALALOVA, S.; VLCEK, V.; KYBAL, J. Mass production of Beauveria bassiana for regulation of Leptinotarsa decemlineata populations. Journal of Invertebrate Patology, v.38, p.169-174, 1981.

SANCHEZ, S.D.; BELLOTTI, A.C. Pathogenicity of fungi hyphomycetes on Cyrtomenus bergi Foreschner (Hemiptera: Cydnidae) cassava burrowing bug. Revista Colombiana de Entomologia, v.23, n.1/2, p.31-37, 1997. 
SCOMPARIN, C.H.J. Estudo dos crisopídeos (Neuroptera, Chrysopidae) em seringueira (Hevea brasiliensis Müell Arg.), aspectos biológicos e potencial no controle biológico de Leptopharsa heveae Drake \& Poor (Hemiptera, Tingidae). Jaboticabal, 1997. 173p. Dissertação (Mestrado) - Faculdade de Ciências Agrárias e Veterinárias, Universidade Estadual Paulista "Júlio de Mesquita Filho".

SHIMAZU, M.; ALVES, R.T.; KISHINO, K. Investigation on entomogenous fungi in the Cerrado Region and their utilization for microbial control of pests. Relatório técnico do projeto nipo-brasileiro de cooperação em pesquisa agrícola: 1987-1992. p.202214, 1994.

SILVA, M.E. da; FLEIG, E.D. Avaliação de diferentes isolados de fungos entomopatogênicos para controle de Atta sexdens piriventris (Santschi, 1919) (Hymenoptera: Formicidae). Anais da Sociedade Entomológica do Brasil, v.17, n.2, p.263-269, 1988.

SOETOPO, D.; ISKANDAR, M. The efficacy of Mipcin $50 \mathrm{WP}$ and Bassa 50 EC against two major insect pests of pepper. Edisi Khusus Penelitian Tandman Rempah dan Obat, v.11, n.2, p.75-78, 1986.

SORIA, S.; MUNOZ, A.; TORRE, R. de la; JACOSTE, A. Corythuca ciliata (Say, 1832) (Heteroptera: Tingidae) en la Comunidade de Madrid. Boletin Sanidad Vegetal, v.17, n.3, p.440, 1991.

SOSA GOMEZ, D.R.; MOSCARDI, F. Laboratory and field studies on the infection of stink bugs, Nezara viridula, Piezodorus guildinii and Euschistus heros (Hemiptera: Pentatomidae) with Metarhizium anisopliae and Beauveria bassiana in Brazil. Journal of Invertebrate Pathology, v.71, n.2, p.115-120, 1998. 
ST. LEGER, R.J.; CHARNLEY, A.K.; COOPER, R.M. Characterization of cuticledegrading proteases produced by the entomopathogen Metarhizium anisopliae. Archives of Biochemistry and Biophysics, v.253, p.221-232, 1987.

ST. LEGER, R.J.; NELSON, J.O.; SCREEN, S.E. The entomopathogenic fungus Metarhizium anisopliae alters ambient $\mathrm{pH}$, allowing extracellular protease production and activity. Microbiology Reading, v.145, n.10, p.2691-2699, 1999.

STEINKRAUS, D.; ROSENHEIM, J. Biological factors influencing the epizootiology of cotton aphid fungus. In: BELTWIDE COTTON CONFERENCES, 10., San Antonio, 1995. Proceedings. Memphis. 1995. p.887-888.

TAMAI, M.A. Avaliação de fungos entomopatogênicos para o controle de Tetranychus urticae Koch. Piracicaba, 1997. 86p. Dissertação (Mestrado) - Escola Superior de Agricultura "Luiz de Queiroz", Universidade de São Paulo.

TANZINI, M.R.. Resistência a clones de seringueira (Hevea brasiliensis Müell Arg.) a Leptopharsa heveae Drake \& Poor, 1935 (Hemiptera: Tingidae) e sua biologia. Jaboticabal, 1996. 138p. Dissertação (Mestrado) - Faculdade de Ciências Agrárias e Veterinárias, Universidade Estadual Paulista.

TANZINI, M.R. Controle biológico do percevejo-de-renda-da-seringueira. In: CICLO DE PALESTRAS SOBRE CONTROLE BIOLÓGICO DE PRAGAS, 5., Campinas, 1997. Anais. Campinas: IB, 1997. p.32-38.

TANZINI, M.R. Manejo integrado do percevejo-de-renda-da-seringueira e ácaros na Hevea. In: CICLO DE PALESTRAS SOBRE HEVEICULTURA PAULISTA, 1., Barretos, 1999. Anais. Barretos: SAA; APABOR, 1999. p.31-44. 
TANZINI, M.R.; ALVES, S.B. Selection of entomopatogenic fungi in the control of Leptopharsa heveae. In: INTERNATIONAL CONGRESS OF ENTOMOLOGY, 21., Foz do Iguaçú, 2000. Abstract. Londrina: EMBRAPA Soja, 2000 p.543.

TANZINI, M.R.; LARA, F.M. Biologia do percevejo-de-renda-da-seringueira Leptopharsa heveae Drake \& Poor (Heteroptera: Tingidae). Ecossistema, v.23, p.6567, 1998.

TANZINI, M.R.; ALVES, S.B.; SETTEN, A.; AUGUSTO, N.T. Compatibility de agentes tensoactivos com Beauveria bassiana y Metarhizium anisopliae. Manejo Integrado de Plagas, n.59, p.15-18, 2001.

TANZINI, M.R.; ALVES, S.B.; TAMAI, M.A.; MORAES, G.J.de; FERLA, N.J. An epizootic of Calacarus heveae (Acari: Eriophyidae) caused by Hirsutella thompsonii on rubber tree. Environomental and Applied Acarology, v.24, p.141-144, 2000.

TAVELA, L.; ARZONE, A. Indagini sui limitatori di Corythuca ciliata (Say) (Rhynchota: Heteroptera). Redia, v.70, p.443-457, 1987.

TODOVORA, S.I. Compatibility of Beauveria bassiana with selected fungicides and herbicides. Environmental Entomology, v.27, n.2, p.427-433, 1998.

VESTERGAARD, S.; BUTT, T.M.'BRESCIANI, J.; GILlESPIE, A.T.; AILENBERG, J. Light and electron microscopy studies of the infection of the Western flower thrips Frankliniella occidentalis (Thysanoptera: Thripidae) by the entomopathogenic fungis Metarhizium anisopliae. Journal of Invertebrate Pathology, v.73, n.1, p.25-33, 1999. 
VIDAL, C.; FARGUES, J.; LACEY, L.A.; JACKSON, M.A. Effect of various liquid media on morphology, growth, propagule production, and pathogenic activity to Bemisia argentifolii of the entomopathogenic Hyphomycete, Paecilomyces fumososroseus. Mycopathologia, v.143, n.1, p.33-46, 1998a.

VIDAL, C.; OSBORNE, L.S.; LACEY, L.A.; FARGUES, J. Effect of host plant on the potential of Paecilomyces fumosoroseus (Deuteromycotina: Hyphomycetes) for controlling the silverleaf whitefly, Bemisisa argentifolii (Homoptera: Aleyrodidae) in greenhouses. Biological Control, v.12, n.3, p.191-199, 1998b.

VIEIRA, S.A.; ALVES, S.B.; STIMAC, J.L.; ESTEVAM, R.C. Seleção de isolados de Metarhizium anisopliae e Beauveria bassiana para o controle de Periplaneta americana (L.). In: CONGRESSO BRASILEIRO DE ENTOMOLOGIA, 14., ENCONTRO NACIONAL DE FITOSSANITARISTAS, 5., Piracicaba, 1993. Anais. Piracicaba: SEB, 1993. p.347.

VILAS BOAS, A.M.; ANDRADE, R.M.; OLIVEIRA, J.V. Diversificação de meios de cultura para produção de fungos entomopatogênicos. Arquivos de Biologia e Tecnologia, v.39, n.1, p.123-128, 1996.

WATANABE, M.A.; YOSHII, C.; SILOTO, R.C. Parasitism of the scale insect Selenaspidus articulatus (Morgan, 1889) (Hemiptera/Homoptera, Diaspididae) on citrus in the regions of Jaguariuna and Limeira, SP. Revista de Agricultura de Piracicaba, v.69, n.2, p.193-200, 1994.

WESELOH, R.M.; ANDREADIS, T.G. Epizootiology of the Entomophaga maimaiga, and its impact on gypsy moth populations. Journal of Invertebrate Pathology, v.59, n.2, p.133-141, 1992. 
WRAIGHT, S.P.; CARRUTHERS, R.I.; BRADLEY, C.A.; JARONSKI, S.T.; LACEY, L.A.; WOOD, P.; WRAIGHT, S. Pathogenicity of the entomopathogenic fungi Paecilomyces spp. and Beauveria bassiana against the silverleaf whitefly, Bemisia argentifolii. Journal of Invertebrate Pathology, v.71, n.3, p.217-226, 1998.

WRIGHT, J.E. Control of the boll weevil (Coleoptera: Curculionidae) with Naturalis-L: a mycoinseticide. Journal of Economic Entomology, v.86, n.5, p.1355-1358, 1993.

WRIGHT, J.E.; KNAUF, T.A. Evaluation of Naturalis-L for control of cotton insects. In: BRIGHTON CROP PROTECTION CONFERENCE, PESTS AND DISEASES, 3., Brighton, 1994. Proceedings. Brighton, 1994. p. 45-52.

YACOOB, M.; LIVINGSTONE, D.; GOEL, S.C. Resouce potentials of the egg parasitoids of Tingidae. In: GOEL, S.C. (Ed.) Insect ecology and resource management. Muzaffarnagar: Sanatan Dharn College, 1983. p.247-252.

ZECHINI D’AURELIO, A.; MARCHETTI, L.; VALlE, E.; GIOVANNI, G. de; BADIALI, G.; BOSELlI, M.; LODI, M. Controllo simultaneo su platano di Gnomonia platani (Kleb.) e Corythuca ciliata (Say.) con iniezioni di fitofarmaci al tronco. Informatore. Fitopatologico, v.40, n.5, p.59-63, 1990. 